\title{
LA PERSPECTIVA DE COSTA RICA SOBRE EL APOYO OFICIAL TOTAL PARA EL DESAROLLO SOSTENIBLE (TOSSD)
}

Marisa Berbegal-Ibáñez, Juan Casado-Asensio, Friederike Ruhmann, Aussama Bejraoui, Guillaume Delalande y Julia Benn
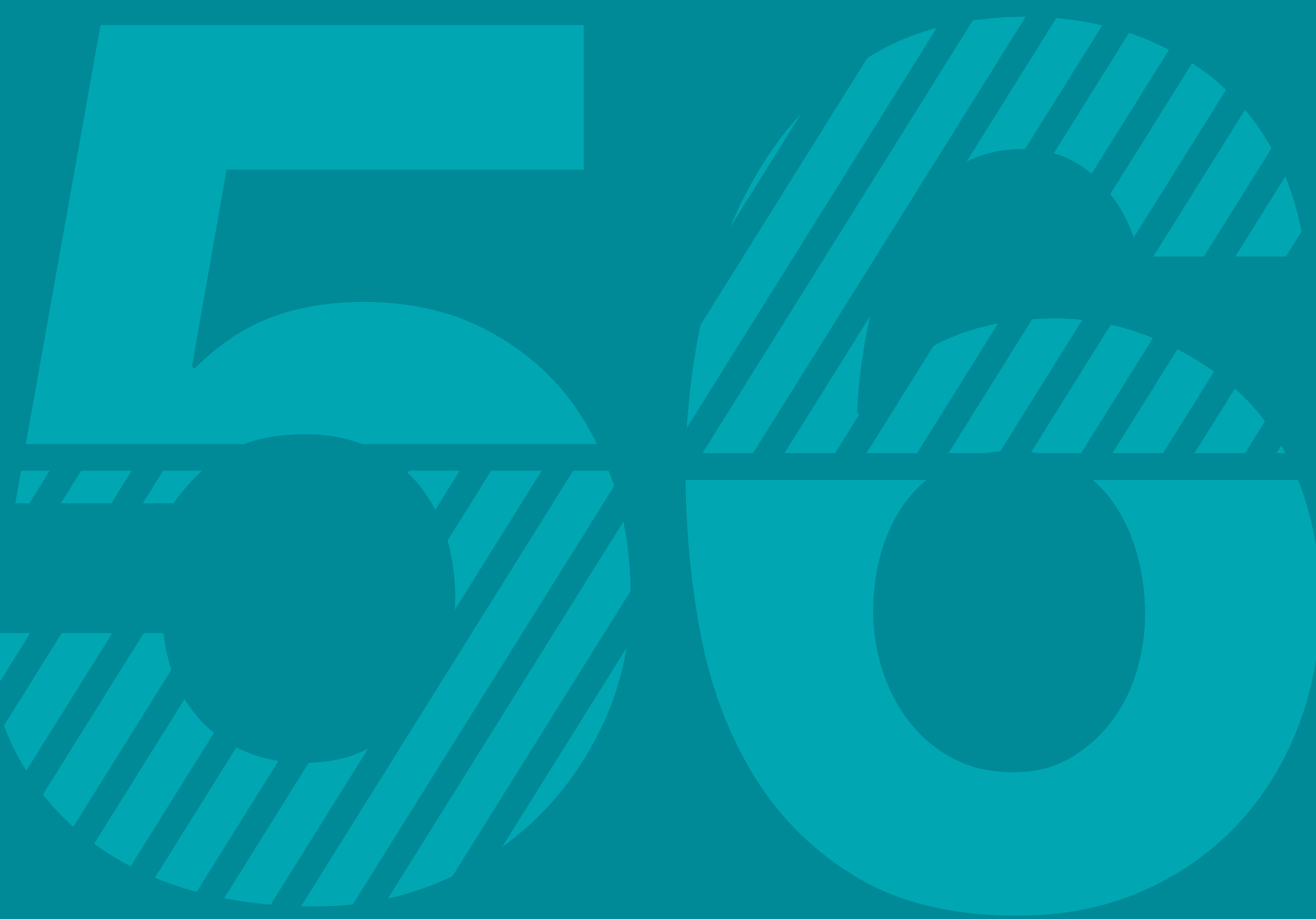

OECD DEVELOPMENT CO-OPERATION DOCUMENTO DE TRABAJO 56

Autorizado para su publicación por Jorge Moreira da Silva, Director de la Dirección de Cooperación para el Desarrollo 


\section{Tabla de Contenidos}

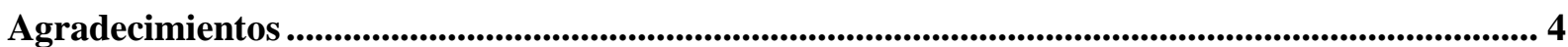

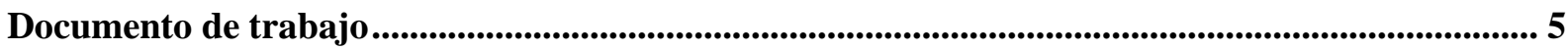

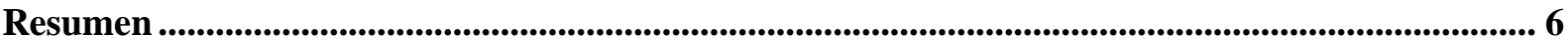

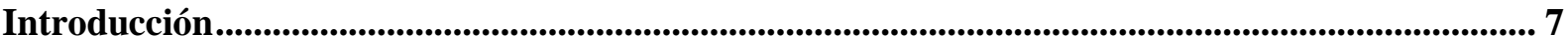

Parte I. Principales hallazgos y recomendaciones ...................................................................................... 8

1. Hallazgos principales del piloto............................................................................................................................ 9

2. Utilidad de TOSSD desde la perspectiva de Costa Rica .......................................................... 13

3. Volumen de los flujos TOSSD hacia Costa Rica...................................................................... 14

4. Recomendaciones a Costa Rica en la colecta, recopilación y diseminación de información sobre financiación para el desarrollo......................................................................................................... 16

Parte II. Información sobre los estudios de piloto de TOSSD y el contexto de Costa Rica .......... 19

1. Contexto y objetivos del estudio piloto ............................................................................................................. 20

2. El contexto económico-financiero de Costa Rica......................................................................... 24

Parte III. Perspectivas de Costa Rica sobre las instrucciones de reporte preliminares................. 30

1. Preámbulo de las instrucciones de reporte, principales conceptos y definiciones ....................... 31

2. Primer pilar del TOSSD: flujos transfronterizos de recursos para apoyar el desarrollo sostenible ................................................................................................................................................................... 40

3. Segundo pilar del TOSSD: los bienes públicos globales ...................................................................... 48

4. Formato de reporte, ciclo de reporte e instrucciones detalladas ............................................... 49

Parte IV. Perspectiva de Costa Rica como proveedor de cooperación al desarrollo...................... 52

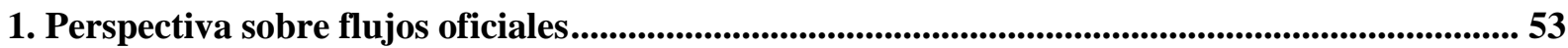

2. Perspectiva sobre otros flujos transfronterizos que pueden ser parte de "indicadores satélite": inversiones privadas, filantropía privada y remesas .............................................................. 55

Parte V. Evaluación de la capacidad del gobierno de costa rica para acceder, recopilar, analizar y utilizar flujos oficiales y privados externos .........................................................................5 56

1. Descripción general de la arquitectura institucional legal para datos de financiamiento del

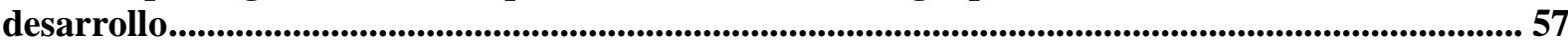

2. Evaluación de la capacidad del gobierno de Costa Rica para gestionar datos sobre financiación para el desarrollo ...................................................................................................60

Conclusiones y próximos pasos .................................................................................................................. 65

Anexos....................................................................................................................................................................... 66

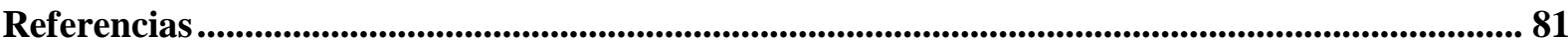




\section{Tablas}

Tabla 1. Magnitud de los flujos de TOSSD hacia costa rica, millones de dólares estadounidenses desembolsos.

Tabla 2. Finanzas de desarrollo oficial y créditos de exportación con apoyo oficial a Costa Rica ....... 27

Tabla 3. Estimaciones de los recursos movilizados desde el sector privado por intervenciones oficiales externas en Costa Rica por proveedor y mecanismo de apalancamiento.

Tabla 4. Estimaciones de los recursos movilizados desde el sector privado por intervenciones oficiales externas en Costa Rica por año y mecanismo de apalancamiento ...

Tabla 5. Estimaciones de los recursos movilizados desde el sector privado por intervenciones oficiales externas en Costa Rica por sector y mecanismo de apalancamiento

\section{Gráficos}

Gráfico 1. Entradas netas de IDE 29

Gráfico 2. El marco de medición estadística del TOSSD se sustenta en dos pilares.............................. 36

Gráfico 3. Perspectiva general del pilar de los flujos transfronterizos de recursos del TOSSD............ 41

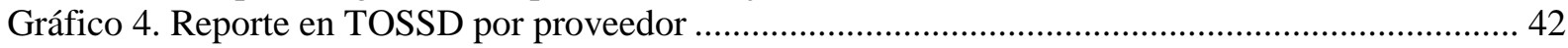

Gráfico 5. Ejemplos de habilitadores del desarrollo y retos globales.................................................. 48

Gráfico 6. Formulario de reporte por nivel de actividad para los flujos transfronterizos del TOSSD

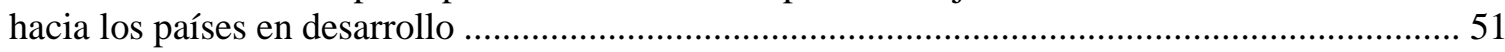

Gráfico 7. Ejemplo de un acuerdo de financiación complejo: el proyecto del tren de pasajeros de la zona suburbana de San José

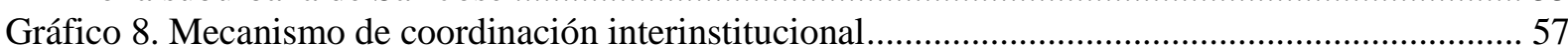

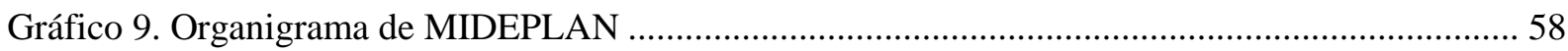

\section{Cuadros}

Cuadro 1. La Iniciativa de las Finanzas para la Biodiversidad (BIOFIN) 34 


\section{Agradecimientos}

Los autores (Marisa Berbegal-Ibañez, Juan Casado-Asensio, Friederike Ruhmann, Aussama Bejraoui, Guillaume Delalande and Julia Benn) desean agradecer al Gobierno de Costa Rica y en particular a la Dirección de Cooperación Internacional del Ministerio de Planificación Nacional y Economía Política (Mideplan) por organizar y coordinar el estudio piloto en el país. La valiosa contribución de Costa Rica ayudó a ofrecer condiciones óptimas para el desarrollo de este estudio piloto.

La Secretaría también desea agradecer a todo el personal de las instituciones (mencionado en el Anexo C) que se reunieron durante la misión en el país por su valioso tiempo.

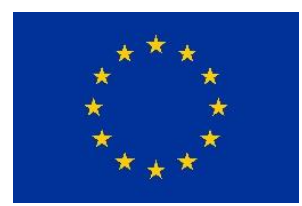

Asimismo, los autores agradecen a Emily Bosch y Stacey Bradbury por revisar el documento y proporcionar comentarios muy útiles al respecto.

Finalmente, los autores desean agradecer a la Unión Europea por el apoyo financiero que permitió llevar a cabo este estudio piloto en el país, que proporciona información crítica para el trabajo del Grupo de trabajo internacional TOSSD y la posibilidad de probar los diversos parámetros y metodologías de TOSSD.

Co-financiado por la Unión Europea 


\section{Documento de trabajo}

Los documentos de trabajo de la OCDE no representan las opiniones oficiales de la OCDE o de sus países miembros. Las opiniones expresadas y los argumentos empleados son de los autores.

Los documentos de trabajo describen los resultados preliminares o las investigaciones en curso de los autores y se publican para estimular el debate sobre una amplia gama de temas en los que trabaja la OCDE. Los comentarios sobre el presente documento de trabajo son bienvenidos y pueden enviarse a dac.contact@oecd.org - la Dirección de Cooperación para el Desarrollo, OCDE, 2 rue André-Pascal, 75775 Paris Cedex 16, France. 


\section{Resumen}

Este documento de trabajo resume los principales hallazgos y recomendaciones del estudio piloto realizado en Costa Rica como parte del desarrollo del marco de medición del apoyo oficial total al desarrollo sostenible (TOSSD). El documento incluye los flujos estimados de TOSSD a Costa Rica. Estos flujos en 2016 fueron de 559 millones de dólares estadounidenses de financiamiento oficial para el desarrollo y 60 millones de dólares de financiación privada movilizada a través de intervenciones oficiales de desarrollo. Estos flujos se calcularon a partir de las estadísticas CAD de la OCDE. Sin embargo, es probable que las cifras estén subestimadas en gran medida debido a la falta de información disponible, en particular con respecto al apoyo oficial a Costa Rica por parte China y otros países proveedores que no pertenecen al CAD. El estudio piloto también indicó que el gobierno puede acceder, recopilar, analizar y usar datos sobre financiamiento externo para el país utilizando datos nacionales gracias a sus sistemas institucionales y de tecnologías de la información. Sin embargo, el marco legislativo requiere ajustes y puede mejorarse la coordinación con el fin de evitar la duplicación de esfuerzos. 


\section{Introducción}

Este documento presenta los resultados del estudio piloto nacional llevado a cabo en Costa Rica sobre el nuevo marco de medición de TOSSD, incluidas las conclusiones de la misión en el país realizada del 24 de septiembre al 5 de octubre de 2018.

La Parte I resume los principales hallazgos y recomendaciones del estudio piloto, incluidos los primeros órdenes de magnitud de flujos de TOSSD hacia y desde Costa Rica.

La Parte II proporciona algunos antecedentes sobre el concepto de TOSSD, los objetivos y la metodología de los estudios piloto de TOSSD y expone el panorama económico y financiero de Costa Rica.

La Parte III ofrece comentarios preliminares a las Instrucciones de Reporte TOSSD, tal y como fueron diseñadas por el Grupo de Trabajo de TOSSD en el momento de la misión.

La Parte IV realiza una descripción general del rol de Costa Rica como proveedor de cooperación para el desarrollo (el país tiene un doble rol de proveedor y receptor).

La Parte V proporciona una evaluación de la capacidad del gobierno para recoger, cotejar, usar y diseminar información sobre financiamiento para el desarrollo de fuentes oficiales y privadas con apoyo oficial en Costa Rica. 


\section{Parte I. Principales hallazgos y recomendaciones}

Esta parte del informe presenta los principales hallazgos que surgieron de las entrevistas con la administración de Costa Rica sobre el apoyo oficial total para el desarrollo sostenible (TOSSD). El TOSSD es un marco estadístico que se encuentra actualmente en desarrollo para captar recursos en apoyo de los objetivos de desarrollo sostenible. Se compone de dos pilares para captar (i) flujos externos a países en desarrollo y (ii) financiamiento para promover los facilitadores del desarrollo y abordar los desafíos globales a nivel regional y global (la agenda de Bienes Públicos Globales), en ambos casos con apoyo oficial.

El objetivo principal de los estudios piloto de TOSSD es identificar cómo TOSSD puede tener en cuenta la perspectiva de los países en desarrollo, así como sus necesidades de información en cuanto a financiación para el desarrollo. También sirven para probar la metodología estadística en el contexto particular de los países y hacer cualquier ajuste de la metodología TOSSD si fuese necesario. Costa Rica fue seleccionada para realizar un estudio piloto porque participa activamente en el desarrollo de TOSSD y porque es un país líder en lo que respecta a su modelo de desarrollo sostenible. 


\section{Hallazgos principales del piloto}

Costa Rica avala la mayoría de los conceptos y clasificaciones incluidos en las instrucciones de reporte, incluida la definición de TOSSD y de desarrollo sostenible. Sin embargo, el enfoque de dos pilares del TOSSD resulta particularmente confuso. Se proporcionan las siguientes sugerencias por parte de la administración costarricense:

- Existe amplio acuerdo en el concepto de desarrollo sostenible. La operacionalización por parte de Costa Rica es más estricta y se basa en el alineamiento con el Plan Nacional de Desarrollo (PND), en el que prima sobre todo la dimensión ambiental. Esto se explica porque el medio ambiente es la mayor fuente de riqueza nacional. De ahí que algunos interlocutores considerasen que la operacionalización de TOSSD es muy amplia. El próximo documento de planificación será el Plan Nacional de Desarrollo e Inversión Pública que estará alineado con objetivos y metas de los Objetivos de Desarrollo Sostenible de la Agenda 2030. También hay acuerdo general con actualizar TOSSD con la Agenda de desarrollo sostenible post 2030.

- Existe acuerdo general con la definición de "flujos de recursos", haciendo especial hincapié en la importancia para Costa Rica de los flujos de cooperación técnica y financiera no reembolsable. La cooperación técnica se entiende en un sentido amplio y que incluye entre otros, capacitación, intercambio de experiencias, conocimientos, tecnología y sensibilización.

- En cuanto a la definición "con apoyo oficial" hubo acuerdo en la definición. Nadie pudo ofrecer un ejemplo de empresa con influencia significativa del gobierno (cuando el estado posee entre el 10 y el 50\% de las acciones de una compañía) y los diferentes actores que trabajan con el sector privado confirmaron que en el caso de Costa Rica las empresas en las que el estado tiene participación son de titularidad pública.

- Existe una confusión lingüística en cuanto al primer pilar, puesto que "cooperación transfronteriza" es un concepto que se refiere a cooperación entre países que comparten frontera. Se propone cambiar flujos transfronterizos por "flujos externos". El concepto en inglés resulta claro. Existe asimismo una confusión conceptual en cuanto al segundo pilar. Este pilar se concretará en las próximas reuniones del Grupo de Trabajo TOSSD.

- Muchas de las actividades que tienen lugar en Costa Rica y que se refieren a la gestión de áreas protegidas o recursos naturales tienen efectos y externalidades en otros países de la región por lo que se considera que deberían incluirse en o bien un tercer pilar regional, o bien en el segundo pilar con una desagregación regional. Costa Rica al ser un país pequeño es más interdependiente de la región centroamericana que de la de América Latina y el Caribe, por lo que se propone establecer sub-regiones y no considerar el continente como un todo. En otros sectores podría subsumirse en la región de América Latina, como por ejemplo en la migración.

- Costa Rica propone que se añada en el párrafo 24 de las instrucciones de reporte (que explica el concepto de proveedor y receptor) una tercera categoría de país dual, que es proveedor de cooperación: técnica no reembolsable Sur-Sur y 
triangular, contribuciones a organismos internacionales incluidos los de mantenimiento de la paz, ayuda humanitaria y atención a migrantes y refugiados. También es receptor. TOSSD debería recopilarse tanto de los proveedores como de los países duales. Asimismo, Costa Rica estaría dispuesta a reportar datos de flujos recibidos para triangular información con la de los proveedores, pero habría que establecer un mecanismo de conciliación de datos cuando existan discrepancias, de lo contrario podría suponer una carga para el Secretariado.

- Costa Rica, como proveedor, sería capaz de reportar parcialmente y a partir de 2019. Para reportar en el conjunto de flujos, necesitaría reforzar su capacidad, cambiar el marco legislativo y político y mejorar su coordinación interna.

- Existe acuerdo con incluir el alivio de la deuda como flujos transfronterizos. Costa Rica no está actualmente en ningún proceso de alivio de deuda, pero sí ha recibido canje de deuda por proyectos ambientales en el pasado.

- Costa Rica no recoge datos de fondos privados movilizados del sector privado.

- Costa Rica no tiene una estrategia para proporcionar contribuciones a organismos multilaterales. La mayoría de las contribuciones son obligatorias y en cualquier caso la toma de decisiones en organismos temáticos está delegada a los Ministerios en función de la materia y no existe coordinación o supervisión al respecto. En la mayor parte de los casos la decisión responde a criterios coyunturales.

- Los funcionarios costarricenses consideraron que las contribuciones a corto plazo deberían incluirse en TOSSD. En su mayoría son flujos que contribuyen a el operativo general de la empresa, lo que redunda en bienestar económico y empleo. No habría diferencia entre que esta financiación provenga de un banco multilateral de desarrollo o de una institución financiera bilateral. Los datos se recogen por el Banco Central.

- Para Costa Rica es importante que TOSSD se vincule a metas de desarrollo, pues se considera que a nivel objetivo es demasiado vago. La Secretaría técnica de MIDEPLAN es responsable de definir los ODS nacionales y se articula también a nivel meta. TOSSD podría complementar la información del Plan Nacional de Desarrollo incluyendo información de flujos externos hacia Costa Rica para cada meta de los ODS.

- Costa Rica ve muy positivo el hecho de que los países puedan optar voluntariamente a la lista de países elegibles para el TOSSD. Si se graduasen como país receptor de Ayuda Oficial para el Desarrollo (AOD) no tendrían inconveniente en optar a TOSSD para asegurar una transición real y efectiva con mecanismos específicos y adecuados de cooperación para la transición.

- Costa Rica acaba de elaborar una metodología para cuantificar la cooperación técnica, tanto la que proporciona como proveedor, como las contrapartidas nacionales de proyectos en los que el país es receptor. Dicha metodología cuantifica por el coste, pero incluye un elemento muy novedoso que estima el valor del conocimiento y experiencia acumulada en función de los años de experiencia del funcionario o experto en la materia de la que se trate. Hasta la fecha el país no había cuantificado la cooperación técnica en especie y se espera que a partir de 2019 empiece a hacerlo. 
- En cuanto a la estructura de gobernanza, hay acuerdo general en ligar la gobernanza al más alto nivel del sistema en el sistema de las Naciones Unidas. Si se establece un sistema de recogida de datos regional (aspecto que Costa Rica considera positivo), la institución con capacidad para llevar a cabo la tarea sería la Comisión Económica para América Latina y el Caribe (CEPAL). La CEPAL incluye la CEA (Comisión Estadística de las Américas) que está estudiando los indicadores de los ODS.

- Para el reporte de cooperación no reembolsable, Costa Rica tiene el sistema SIGECI. En cuanto a la inversión existen tres bases de datos: DELPHOS, SIGADE (Sistema Gestión y Administración de Deuda Externa) y una tercera base del Banco Central. MIDEPLAN gestiona SIGECI y DELPHOS y el Ministerio de Hacienda gestiona SIGADE. Las bases de datos de inversión pública no son compatibles y generan duplicidades. Además, las bases de datos son incompletas.

- En cuanto a sugerencias de campos adicionales en el formato de reporte de TOSSD, se propone:

- Las contrapartidas nacionales para proyectos de desarrollo, lo cual podría incluir tanto las contrapartidas financieras como la monetización de la contrapartida técnica. Esto daría visibilidad al esfuerzo de los receptores de TOSSD;

- Localización geográfica de los proyectos (voluntario);

- Los gastos administrativos del proveedor para cada proyecto;

- Clarificación de la definición de vía de canalización o la creación de dos sub-categorías porque la actual definición tiene difícil encaje en algunos proyectos ya que la entidad que administra los fondos no es necesariamente la que ejecuta; $y$

○ Dos modalidades de cooperación Sur-Sur: tradicional y bidireccional.

- Costa Rica como proveedor dual estaría dispuesta y podría reportar en TOSSD:

- Contribuciones a organismos multilaterales que podría aportar el Ministerio de Hacienda, aunque no se consideran flujos de cooperación al desarrollo. Sin embargo, estarían dispuestos a reportarlo para asegurar la comparabilidad indicando sin embargo su punto de vista en meta datos;

- Cooperación técnica (Sur-Sur y triangular) no reembolsable;

- Contribuciones a organizaciones de mantenimiento de la paz;

- Ayuda a refugiados y migrantes en el país. En principio sería complicado desglosar ambos conceptos;

- Ayuda humanitaria, si bien no se pudo entrevistar a la unidad encargada del mismo;

- Investigaciones en temas para el desarrollo realizadas por las Universidades Públicas; en caso de que se modificase la Ley o se hiciese un acuerdo con las Universidades, que no fueron entrevistadas en este informe.

- Gastos administrativos del funcionamiento de MIDEPLAN y otro personal encargado de cooperación al desarrollo 
- Costa Rica tiene capacidad, tanto como proveedor como receptor, para poder reportar en su totalidad las donaciones y cooperación técnica, pero necesita modificaciones legislativas e institucionales. El apoyo de los cooperantes sería bienvenido para reforzar y crear un sistema único de recogida de datos que se alimente de las diferentes bases de datos existentes y que se crearán en MIDEPLAN (véase la parte V que realiza una evaluación de la capacidad del gobierno para manejar datos de cooperación al desarrollo).

- El Banco Central recopila información de inversión directa extranjera, y parcialmente de filantropía y remesas de migrantes. Estas últimas se estiman mediante encuestas. Para la inversión directa el CINDE (Agencia de Promoción de Inversión de Costa Rica) y las instituciones ligadas al Ministerio de comercio exterior trabajan para que las inversiones se alineen con el Plan Nacional de Desarrollo en temas de sostenibilidad, principalmente ambiental. En cuanto a filantropía y remesas no hay política de alineamiento.

- Hasta hace poco no existía un marco legal para las Alianzas Público Privadas (APPs). Recientemente se han publicado dos decretos que regulan las APP y las Alianzas Público Privadas para el Desarrollo (APPDs) por lo que se estima que exista un aumento de su uso y una mayor información al respecto. Por ello sería deseable que se recogiese esta información en el banco de inversión pública de MIDEPLAN para capturar tanto la información pública como la privada, en colaboración con el Centro Nacional de Concesiones (CNC). 


\section{Utilidad de TOSSD desde la perspectiva de Costa Rica}

Los datos de TOSSD se utilizarían principalmente por MIDEPLAN. También podrían ser útiles para la Cancillería, Hacienda, Contraloría y Presidencia por el enfoque de gobierno abierto. En particular, TOSSD puede resultar útil para:

\section{Planificación del desarrollo}

- Identificar necesidades de financiación de la Agenda 2030. En este sentido sería útil en la medida en que haya una relación directa con las metas.

- Permitir una mayor planificación en cooperación al desarrollo e inversión a medio y largo plazo al incluir información sobre compromisos, que no se recogen actualmente en SIGECI.

- Entender cómo se alinea la cooperación al desarrollo con la estrategia nacional de desarrollo sostenible.

\section{Transparencia de la información y monitoreo}

- Incrementar la transparencia y la rendición de cuentas en el país. Dar seguimiento y apoyar la función de evaluación de la política de cooperación al desarrollo en el país. Acceder a información sobre inversiones o flujos de recursos que se dirigen a Costa Rica y compararlos con los flujos que se dirigen a otros países de la región.

- Identificar brechas de financiación que se están cerrando en otros países para informar la toma de decisiones de política fiscal nacional (proceso presupuestario y de contabilidad nacional).

- Triangular información sobre financiación para el desarrollo sostenible disponible por parte de la administración, aunque se reconoce que sería complicado reconciliar las diferencias y en este sentido sería necesario reforzar la capacidad para este proceso de conciliación.

- Establecer un sistema de recogida de información en cuanto a la atención de migración y refugio, para saber cuánto se está invirtiendo como proveedor, para toma de decisiones, rendición de cuentas, transparencia y reforzar los sistemas de planificación.

- Disponer de información de fondos privados movilizados, que no se recogen actualmente.

\section{Visibilidad internacional de los esfuerzos de Costa Rica por alcanzar el desarrollo} sostenible

- Dar visibilidad a la agenda de sostenibilidad de Costa Rica, lo cual podría atraer fondos adicionales.

- Visibilizar las contrapartidas nacionales, si se incluyen en el formato de reporte para poder demostrar a los cooperantes que a pesar de la crisis fiscal el país está realizando un esfuerzo importante.

- Conocer qué actividades se implementan a través de ONGs y otros actores, porque la administración no recoge esta información en la actualidad. 


\section{Volumen de los flujos TOSSD hacia Costa Rica}

Los montos estimados de TOSSD a Costa Rica son de 559.1 millones de dólares estadounidenses, lo que incluye 499.2 millones de financiación oficial y 59.9 millones de financiación privada movilizada por intervenciones públicas.

Tabla 1. Magnitud de los flujos de TOSSD hacia costa rica, millones de dólares estadounidenses desembolsos

\begin{tabular}{|c|c|c|}
\hline Categoría de flujo & $\begin{array}{l}\text { Estimaciones en } \\
\text { millones USD } \\
(2016)\end{array}$ & Notas y fuentes \\
\hline \multicolumn{3}{|l|}{ A. SUBSIDIOS } \\
\hline \multicolumn{3}{|c|}{ Flujos bilaterales oficiales de los proveedores del CAD ${ }^{1}$ (excluidas las instituciones de la UE) } \\
\hline $\begin{array}{l}\text { Subvenciones (excluida la } \\
\text { cooperación técnica) }\end{array}$ & 23.1 & $\begin{array}{c}\text { Subvenciones a Costa Rica por los proveedores del CAD, excluida la cooperación técnica } \\
\text { pero incluido el alivio de la deuda }\end{array}$ \\
\hline Cooperación técnica & 10.8 & Cooperación técnica a Costa Rica por parte de los proveedores del CAD \\
\hline \multicolumn{3}{|c|}{ Flujos bilaterales oficiales de proveedores que no forman parte del CAD ${ }^{2}$} \\
\hline $\begin{array}{l}\text { Subvenciones (excluida la } \\
\text { cooperación técnica) }\end{array}$ & 0.3 & Subvenciones a Costa Rica por los proveedores del CAD, excluida la cooperación técnica \\
\hline Cooperación técnica & 0 & Cooperación técnica a Costa Rica por parte de los proveedores del CAD \\
\hline \multicolumn{3}{|c|}{ Flujos oficiales de instituciones multilaterales (incluidas instituciones de la UE) - Fondos fiduciarios también incluidos } \\
\hline $\begin{array}{l}\text { Subvenciones (excluida la } \\
\text { cooperación técnica) }\end{array}$ & 17.9 & Subvenciones a Costa Rica por instituciones multilaterales, excluida la cooperación técnica \\
\hline Cooperación técnica & 0.2 & Cooperación técnica a Costa Rica por parte de instituciones multilaterales \\
\hline \multicolumn{3}{|c|}{ B. TRANSACCIONES FINANCIERAS } \\
\hline \multicolumn{3}{|c|}{ Flujos bilaterales oficiales de los proveedores del CAD (excluidas las instituciones de la UE) } \\
\hline Transacciones de capital & 110.7 & $\begin{array}{c}\text { Préstamos concesionales y no concesionales, financiamiento mezzanine, capital y acciones } \\
\text { en vehículos de inversión colectiva a Costa Rica por parte de proveedores del CAD }\end{array}$ \\
\hline \multicolumn{3}{|c|}{ Flujos bilaterales oficiales de proveedores que no forman parte del CAD } \\
\hline Transacciones de capital & 0 & $\begin{array}{c}\text { Préstamos concesionales y no concesionales, financiamiento mezzanine, acciones y } \\
\text { participación en vehículos de inversión colectiva a Costa Rica por parte de proveedores } \\
\text { que no pertenecen al CAD }\end{array}$ \\
\hline \multicolumn{3}{|c|}{ Flujos oficiales de instituciones multilaterales (incluidas instituciones de la UE) } \\
\hline Transacciones de capital & 336.2 & $\begin{array}{c}\text { Préstamos concesionales y no concesionales, financiación mezzanine, equidad y acciones } \\
\text { en vehículos de inversión colectiva a Costa Rica por instituciones multilaterales }\end{array}$ \\
\hline Flujos oficiales totales $(A+B)$ & 499.2 & \\
\hline \multicolumn{3}{|c|}{ C. Financiamiento privado movilizado a través de intervenciones oficiales } \\
\hline
\end{tabular}

\footnotetext{
1 Los países proveedores del CAD incluyen: Australia, Austria, Bélgica, Canadá, República Checa, Dinamarca, Finlandia, Francia, Alemania, Grecia, Hungría, Islandia, Irlanda, Italia, Japón, Corea, Luxemburgo, Países Bajos, Nueva Zelanda, Noruega, Polonia, Portugal, Eslovaquia, Eslovenia, España, Suecia, Suiza, Reino Unido, Estados Unidos.

2 Incluye información de 20 países que no son miembros del CAD pero que reportan sus actividades de cooperación al desarrollo.
} 
Financiamiento

movilizado por intervenciones

oficiales de desarrollo
En base a las estimaciones de la encuesta 2013-2015 del CAD de la OCDE sobre montos movilizados o fuentes oficiales de Costa Rica, de estar disponibles.

Fuente: OECD (n.d.[1]), Creditor Reporting System, https://stats.oecd.org/

Las discusiones en talleres de expertos y eventos internacionales y en estudios pilotos anteriores han demostrado que los créditos a la exportación con apoyo oficial y la financiación a corto plazo también pueden contribuir al cumplimiento de los ODS y ser incluidos en TOSSD. Los créditos a la exportación con apoyo oficial ascendieron a 6.3 millones de dólares estadounidenses en 2016. La información sobre financiación a corto plazo está en principio disponible en el Banco Central. Más allá de TOSSD, Costa Rica piensa que los flujos privados en términos de mercado (por ejemplo, la IDE) y las donaciones caritativas pueden proporcionar también información útil sobre flujos externos hacia el país. 


\section{Recomendaciones a Costa Rica en la colecta, recopilación y diseminación de información sobre financiación para el desarrollo}

- Costa Rica tiene un buen sistema de recogida de información para la cooperación al desarrollo y una administración que cuenta con la capacidad y los recursos humanos y técnicos necesarios para llevar a cabo su labor. El país tiene medios técnicos suficientes, tales como equipos informáticos, bases de datos, personal cualificado en la materia, y un sistema de recogida de información y de coordinación. Igualmente dispone de diversos portales para hacer la información accesible a la ciudadanía, tal y como la plataforma SIGECI o el mapa de inversiones.

- Sin embargo, el país debería asegurar que el sistema de SIGECI recoge la integralidad de recursos no reembolsables para el desarrollo sostenible. Ello implica la recogida de datos de cooperación a nivel no sólo nacional sino también regional, ayuda humanitaria, contribuciones a organismos multilaterales y operaciones de mantenimiento de la paz, becas y formación recibida; y ayuda a refugiados y posiblemente migrantes. Por ello se insta a todas las instituciones costarricenses, incluidos no sólo los Ministerios sino también las entidades autónomas y semi-autónomas a registrar sus actividades utilizando el formato establecido por MIDEPLAN de manera regular y al menos una vez al año.

- Ello necesitaría la elaboración de un marco legal que obligue a estos organismos autónomos, incluidas las universidades públicas, a reportar sus proyectos e iniciativas de cooperación. El tener un sistema de información más completo permitirá que MIDEPLAN pueda ejercer mejor su mandato de planificación, mejorar la coordinación con los cooperantes que operan en Costa Rica y asesorar mejor acerca de las necesidades de inversión pública en el país.

- La coordinación entre actores podría mejorar. Por ejemplo, la coordinación entre Cancillería, que se encarga del alineamiento de la cooperación al desarrollo con la política exterior del país y MIDEPLAN, que coordina a nivel técnico los datos y el alineamiento con el Plan Nacional de Desarrollo, debe mejorar. Esto permitiría asegurar que toda la información sobre flujos de recursos de cooperación al desarrollo, que pasa por Cancillería, así como los datos sobre becas recibidas, estén incluidas dentro de SIGECI.

- Para evitar un exceso de carga de trabajo a MIDEPLAN, que con el personal actual no podría asumir fácilmente, sería deseable permitir la recogida de datos descentralizada por parte de los enlaces. Por ejemplo, los Ministerios rectores podrían ser los encargados de recoger y validar la información tanto de sus Ministerios como de los organismos autónomos adscritos al mismo, y una vez recopilados, enviar a MIDEPLAN para su aprobación. Esto reduciría la carga de trabajo, incrementaría la información recogida en SIGECI y aseguraría dos mecanismos de control de calidad antes del envío al Secretariado de TOSSD, lo cual mejoraría la calidad del reporte. Para ello se necesitaría rediseñar el sistema de coordinación de la recogida de datos y adaptar la plataforma SIGECI para que tenga la capacidad de implementar estos cambios. 
- En cuanto a la cooperación técnica sería deseable recoger por parte de las instituciones que reporten a MIDEPLAN el desglose de funcionarios, viáticos, alojamiento, etc. Esto permitiría por una parte revisar que la nueva metodología se está aplicando correctamente y por otra reportar en TOSSD según la metodología que adopte el Grupo de Trabajo TOSSD, o bien en ambas metodologías durante un periodo de prueba.

- Igualmente debe asegurarse que las bases de datos de DELPHOS, SIGADE y la plataforma de inversión del Banco Central sean interoperables, se comparta información y se eviten duplicidades, pérdida de recursos y de esfuerzo en la duplicación de estos gastos ya que el reporte es una labor adicional para los Ministerios. Sería deseable que el Ministerio de Hacienda, MIDEPLAN y el Banco Central se pusiesen de acuerdo en un sistema que pueda ser compartido por todas las instituciones y que recoja la información necesaria para la toma de decisiones por parte de ambos. Igualmente, la información debería sistematizarse para poder reportar en TOSSD las inversiones recibidas.

- El apoyo de los cooperantes sería bienvenido para reforzar y crear un sistema único de recogida de datos que se alimente de las diferentes bases de datos existentes y que se crearán.

- La plataforma DELPHOS podría recoger datos de financiación privada apalancada en proyectos de blended finance, a partir de la información proporcionada por los donantes. También podría incluir información de financiación privada apalancada en proyectos de APPDs y en este sentido podría incluirse un mandato legal dentro del decreto de APPDs para recoger dicha información.

- La base de datos de SIGECI y de inversión pública deberían asimismo ser compatibles e idealmente que puedan consultarse desde una misma fuente para facilitar una visión de conjunto y una mejor planificación. Para ello se requeriría una armonización de sus campos puesto que las bases de datos tienen objetivos diferentes.

- Idealmente estos cambios deberían introducirse a la mayor brevedad posible para que Costa Rica pueda empezar a reportar sus datos de TOSSD en el primer semestre de 2019.

- Sería deseable que Costa Rica recogiese la información de la financiación privada en apoyo al desarrollo sostenible, al menos para los esquemas de financiación público privados. MIDEPLAN en colaboración con el CNC sería un órgano con capacidad y voluntad para llevar a cabo este ejercicio.

- Costa Rica debería buscar un mandato político interno para la coordinación de su política de cooperación al desarrollo. Costa Rica como país de renta mediaalta debe posicionarse ante el cambio de la cooperación al desarrollo actual, donde los proveedores esperan que los países adopten un rol más pro-activo en cuanto a la gestión de su cooperación. En cuanto a la mejora de la coordinación, MIDEPLAN podría volver a liderar una mesa de coordinación de donantes para poder planificar la cooperación al desarrollo y alinear mejor los recursos con las necesidades.

- MIDEPLAN podría trabajar con la OCDE y con sus países miembros en temas de cooperación al desarrollo para aprovechar los recursos técnicos y experiencia 
acumulada en la elaboración de estadísticas, manejo de bases de datos, diseño e implementación de proyectos bilaterales y triangulares, etc.

- Costa Rica es líder mundialmente reconocida en cuanto a su enfoque de desarrollo sostenible, y un impulsor claro de TOSSD. Debería utilizar su posición como líder regional en la materia para dar a conocer tanto a nivel político como técnico TOSSD en la región y los beneficios que puede reportar para medir las agendas nacionales 2030 y para incentivar recursos a países de renta media-alta o recientemente graduados de AOD. 


\section{Parte II. Información sobre los estudios de piloto de TOSSD y el contexto} de Costa Rica

Esta parte del informe explica brevemente el concepto de TOSSD, la metodología y los objetivos de los estudios piloto de TOSSD y explica por qué Costa Rica fue considerada una candidata ideal y, por lo tanto, fue seleccionada para realizar un estudio piloto de TOSSD. 


\section{Contexto y objetivos del estudio piloto}

\subsection{El concepto de TOSSD}

Actualmente, muchos países en desarrollo dependen cada vez menos de la ayuda oficial para el desarrollo (AOD) y reciben cada vez más otros tipos de apoyo oficial, incluyendo recursos no concesionales y capital privado, normalmente en acuerdos de cofinanciación con financiación pública. Asimismo, y con un número cada vez mayor de actores, es necesario un marco de medición transparente e inclusivo que pueda medir la totalidad de los flujos de recursos externos con apoyo oficial para el desarrollo sostenible.

La Agenda de Acción de Addis Abeba (AAAA) instaba a la comunidad internacional a hacer frente al problema de la financiación y de la creación de un entorno propicio a todos los niveles para el desarrollo sostenible, reconociendo la función especial continuada del financiamiento oficial para el desarrollo y al mismo tiempo la necesidad de catalizar otros recursos para apoyar el desarrollo de los países, dentro de un proceso consultivo inclusivo y transparente.

Desde la conferencia de Addis Abeba, la OCDE ha estado trabajando en consulta con la comunidad internacional para desarrollar un nuevo marco de medición para la era de los objetivos para el desarrollo sostenible (ODS) llamado Total Official Support for Sustainable Development (TOSSD). El marco de TOSSD tiene como objetivo proporcionar una imagen completa del apoyo oficial externo hacia el desarrollo sostenible y los flujos movilizados a través de intervenciones oficiales, facilitando así un estándar común internacional de reporte para todos los proveedores de cooperación para el desarrollo, incluidas las economías emergentes.

TOSSD está diseñado expresamente para dar seguimiento a los recursos invertidos para lograr el desarrollo sostenible y abarcará toda la financiación proporcionada por instituciones oficiales bilaterales y multilaterales, independientemente del nivel de concesionalidad involucrado o el instrumento utilizado. Incluye financiación concesional y no concesional provisto a través de varios instrumentos, como pueden ser las donaciones, préstamos, inversiones de capital o financiación mezzanine, entre otros. También tiene como objetivo abarcar actividades que promuevan y permitan el desarrollo sostenible, incluidas las contribuciones a los bienes públicos globales que sean relevantes para el desarrollo. Su objetivo es crear los incentivos apropiados para utilizar las finanzas públicas internacionales y los instrumentos de mitigación de riesgos para movilizar recursos adicionales para el desarrollo.

El marco de medición de TOSSD ${ }^{3}$ actualmente se compone de dos pilares que realizan un seguimiento de i) flujos transfronterizos oficiales o externos a países en desarrollo y ii) financiamiento para promover facilitadores del desarrollo y abordar desafíos globales a nivel regional y global.

3 Para más información sobre el TOSSD, vea: http://www.oecd.org/dac/financing-sustainabledevelopment/tossd.htm 
En el primer semestre de 2017, un Grupo de Trabajo internacional ${ }^{4}$ se estableció para llevar a cabo el trabajo técnico requerido para operacionalizar TOSSD y garantizar que se ajuste a las normas estadísticas internacionales.

\subsection{La participación de países socios y proveedores de cooperación Sur-Sur en el marco de TOSSD}

Con el fin de establecer TOSSD como una norma estadística internacional viable, relevante y sólida, el apoyo y la participación de los países en desarrollo y de los proveedores de cooperación Sur-Sur es fundamental. La OCDE llevó a cabo tres estudios piloto para obtener perspectivas valiosas de los países receptores de TOSSD así como una mejor comprensión del potencial de TOSSD de convertirse en un marco global. Los estudios se desarrollaron entre 2016 y 2018, antes de comenzar a desarrollar dicho marco estadístico [Senegal (Delalande, G. y V. Gaveau, 2018) y Filipinas (Delalande, G., R. Halvorson-Quevedo y C. Sangaré, 2018] y durante el desarrollo de las instrucciones de reporte TOSSD [Nigeria (Delalande, G., et al., 2018)]. Estos pilotos arrojan luz sobre preocupaciones de los países acerca de los criterios de elegibilidad (por ejemplo, la inclusión de ciertos costos incurridos y desembolsados en países proveedores), enfoques de medición (por ejemplo, el uso de paridades de poder adquisitivo) o las características necesarias para que el marco pueda apoyar las políticas y planificación de los países (por ejemplo, las cuentas nacionales, balanza de pagos, sostenibilidad de la deuda). El piloto de Costa Rica presentado en este informe se basa en el borrador de las instrucciones de reporte de TOSSD que han sido desarrolladas por el equipo de trabajo internacional de TOSSD. Para este estudio se utilizó la versión 1.0 del 12 de julio de $2018^{5}$.

\subsection{Objetivos y metodología del estudio piloto}

El principal objetivo del estudio piloto propuesto es identificar cómo TOSSD puede tener en cuenta la perspectiva de Costa Rica y satisfacer sus necesidades de información sobre la financiación para el desarrollo, así como comprobar si la metodología estadística es aplicable al contexto particular del país. Más específicamente, el estudio piloto apunta a:

- Refinar y probar la metodología estadística de TOSSD en términos de la naturaleza de las actividades e instrumentos que están propuestos para su inclusión en el marco; informar sobre los posibles límites de medición de TOSSD (por ejemplo, grado de cobertura del financiamiento comercial a corto plazo); así como informar sobre los posibles criterios de elegibilidad.

- Estimar los flujos de TOSSD hacia y desde Costa Rica.

- Llevar a cabo una evaluación no exhaustiva de la capacidad de Costa Rica para acceder, cotejar, analizar y utilizar datos sobre financiación externa oficial y privada en apoyo al desarrollo sostenible.

\footnotetext{
4 Para más información sobre el Grupo de Trabajo TOSSD, vea: http://www.oecd.org/dac/financingsustainabledevelopment/development-finance-standards/tossd-task-force.htm

${ }^{5}$ Disponible en http://www.oecd.org/dac/financing-sustainable-development/developmentfinancestandards/Emerging\%20excerpts\%20of\%20TOSSD $\% 20$ Reporting\%20Instructions_as $\% 20$ of $\% 2$ 012\%20July.pdf
} 
- Probar las metodologías actuales del grupo de trabajo internacional de TOSSD para valorar la cooperación técnica.

El Grupo de Trabajo de TOSSD está desarrollando actualmente el marco de TOSSD y el estudio piloto tendrá como objetivo apoyar la labor del Grupo de Trabajo centrándose en temas específicos que también son particularmente relevantes en el contexto de Costa Rica.

La metodología del estudio piloto consta de tres fases: (a) una revisión de la documentación y estadísticas existentes, (b) una misión en el país que se celebró entre el 24 de septiembre de 2018 y el 5 de octubre de 2018, y (c) el informe final del estudio piloto.

- Revisión documental: se realizó un análisis estadístico de los datos disponibles sobre la financiación para el desarrollo sostenible hacia y desde Costa Rica, basándose en datos de la OCDE sobre recursos oficiales concesionales y no concesionales y datos de otras fuentes internacionales, por ejemplo, del Banco Mundial, FMI, UNCTAD, fuentes de datos bancarios y de negocios privados, etc. También se analizó la documentación clave relacionada con la situación de la financiación del desarrollo sostenible del país, incluyendo el plan nacional de desarrollo de Costa Rica, presupuesto y planificación económica, otros documentos, las tendencias de cooperación al desarrollo y las características, las estrategias nacionales de ayuda al desarrollo, los resultados de la Declaración de París y ejercicios de seguimiento Busan, evaluaciones y análisis por parte de instituciones financieras internacionales. En cuanto al componente de evaluación de la capacidad de Costa Rica, el análisis documental estudió en qué medida Costa Rica produce información sobre entradas oficiales externas de financiación. La revisión documental también permitió afinar la metodología y objetivos específicos para el piloto.

- Misión a Costa Rica: La misión incluyó una serie de entrevistas ${ }^{6}$ diseñadas para reunir los puntos de vista de una amplia gama de actores sobre los objetivos y el alcance de TOSSD, sus características principales y parámetros estadísticos. Dos expertos de la $\mathrm{OCDE}^{7}$ estuvieron en Costa Rica del 24 de septiembre al 5 de octubre 2018. El Gobierno de Costa Rica organizó la agenda de la misión y las entrevistas con dichos actores.

- El informe final, que es este documento.

\subsection{Costa Rica: un candidato ideal para un estudio piloto de TOSSD}

Costa Rica es un candidato ideal para un estudio piloto de TOSSD. Primero, Costa Rica es un miembro activo del Equipo de Trabajo Internacional de TOSSD $^{8}$ creado para desarrollar TOSSD. Costa Rica custodia el $6 \%$ de la biodiversidad mundial y está

\footnotetext{
${ }^{6}$ Consulte el Anexo C para la lista completa de instituciones visitadas durante la misión a Costa Rica.

${ }^{7}$ Marisa Berbegal-Ibañez, Analista de Políticas y Estadísticas, DCD/FOR, Marisa.BerbegalIbanez@oecd.org y Juan Casado-Asensio, Analista de Políticas, DCD/FOR, Juan.CasadoAsensio@ oecd.org.

${ }^{8}$ Organizó la Segunda Reunión del Grupo de Trabajo de TOSSD en San José en Diciembre 2017 y participó en varios eventos de difusión de TOSSD, incluidos eventos en la Comisión de Estadística de las Naciones Unidas o en el Foro de Financiamiento para el Desarrollo en 2018.
} 
comprometida con el desarrollo sostenible, como queda reflejado en su Plan Nacional de Desarrollo y aspiraciones, por ejemplo, a convertirse en país carbono neutral en 2021. También es pionera en la implementación de la Agenda 2030, siendo el primer país del mundo en firmar un Pacto Nacional para cumplir con los ODS. ${ }^{9}$ Una encuesta reciente de la OCDE ha demostrado que Costa Rica es el séptimo receptor más grande de financiación privada movilizada en América Latina a través de intervenciones oficiales de desarrollo (Benn et al. 2017). Costa Rica también tiene una larga experiencia como proveedor de cooperación a otros países, especialmente a través de su Ministerio de Planificación Nacional y Política Económica (MIDEPLAN). Además, cabe señalar que Costa Rica figura como un país de ingreso medio-alto pero que, no obstante, sigue teniendo importantes brechas financieras y de desarrollo estructural (CEPAL 2016). Asimismo, Costa Rica se considera como un país con un rol dual y por lo tanto es receptor de cooperación para el desarrollo y proveedor de cooperación técnica. ${ }^{10}$

9 https://undg.org/silofighters_blog/new-voices-to-build-costa-ricas-future/

${ }^{10}$ Costa Rica considera que las contribuciones obligatorias básicas a las organizaciones multilaterales necesarias para mantener la membresía no pueden ser consideradas como cooperación al desarrollo. 


\section{El contexto económico-financiero de Costa Rica}

\subsection{Situación general económica y de desarrollo}

Costa Rica es una de las democracias más antiguas de América Latina. Ha logrado mantener un sistema político estable a lo largo del tiempo. De acuerdo con la Encuesta Económica de la OCDE de 2018 sobre Costa Rica, el constante progreso económico, social y ambiental ha contribuido a este éxito. Con una población de 5 millones al 30 de junio 2018, el país se ubica por encima del promedio de la OCDE en el Índice para una Vida Mejor (OCDE, 2016). Es un líder mundial en biodiversidad y logró grandes logros en políticas ambientales, convirtiéndolo en el único país tropical en el mundo que ha revertido la deforestación (Banco Mundial, 2018). Considerado un país de ingreso medio-alto, Costa Rica ha experimentado una expansión económica constante durante los últimos 25 años. Con el aumento del nivel de vida y el uso sostenible de los recursos naturales, Costa Rica pudo duplicar su PIB per cápita en las últimas tres décadas (OCDE 2018). Desde 1960, el PIB per cápita de Costa Rica se ha triplicado, el PIB per cápita actualmente representa 10.830 mil dólares estadounidenses (2016) y un PIB total de 56.989 millones de dólares en 2016 (Banco Mundial, 2018). El Índice de Desarrollo Humano de Costa Rica se ubica en el puesto 66 de 188, ocupando un lugar más alto que otros países de la región (Country Economy, 2015). Costa Rica es un país candidato a la OCDE y está trabajando para adoptar las recomendaciones de la Evaluación Económica de la OCDE 2016 (OCDE 2018).

La inflación está volviendo a la meta del Banco Central y el déficit de la cuenta corriente externa sigue reduciéndose. Sin embargo, Costa Rica tiene un déficit fiscal que hace que el país sea vulnerable al ajuste en las condiciones financieras mundiales y que exige una reforma fiscal. En caso de que no se aborden las vulnerabilidades fiscales, la competitividad y la posición externa del país podrían verse negativamente afectadas (FMI 2018). Si bien Costa Rica logró reducir los niveles de pobreza, las desigualdades se mantienen en el país, lo que puede deberse en parte a su estructura tributaria que dificulta la redistribución de los ingresos a través de programas gubernamentales (CEPAL 2016). Además de estas brechas estructurales, Costa Rica se enfrenta a otros desafíos, incluyendo una alta tasa de desempleo (9.5 por ciento en 2016) que afecta principalmente a los jóvenes, una deuda pública de baja capacitación y rápido crecimiento (FMI 2018), la influencia del control estatal en muchos sectores de la economía que restringen la competencia, barreras al emprendimiento y, aunque el gasto en educación sea alto, bajos resultados educativos y grandes desigualdades educativas (OCDE 2018). Además, Costa Rica es vulnerable al cambio climático, que provoca que el fenómeno de El Niño, las inundaciones, los deslizamientos de tierra y los terremotos, entre otros, sean más intensos y que afecten a la infraestructura, ya de por sí relativamente precaria, la producción agrícola y las actividades manufactureras. De acuerdo con los datos de la Comisión Nacional de Emergencias (CNE) y del Ministerio de Planificación y Política Económica (MIDEPLAN), los eventos climáticos extremos provocaron pérdidas económicas por un total de 1.62 miles de millones de dólares entre 2005 y 2016 (NDC 2017). Además, Costa Rica se ve afectada por la creciente crisis política en la vecina Nicaragua, que provoca interrupciones en el comercio entre ambos países, y una creciente migración hacia Costa Rica como país destino. 
El Plan Nacional de Desarrollo (PND) presenta las políticas del gobierno para el mandato de cuatro años del Presidente. El Ministerio de Planificación y Política Económica (MIDEPLAN) tiene la tarea principal de verificar la alineación del PND con los proyectos de inversión pública. MIDEPLAN también aprueba proyectos de inversión de organismos públicos (OCDE 2015). Los Objetivos de Desarrollo Nacional 2030 de Costa Rica, publicados en 2013 por MIDEPLAN con el apoyo del PNUD, son complementarios al Plan Nacional de Desarrollo cuatrienal. El Plan Nacional de Desarrollo actual (2015-2018) refleja la ambición del gobierno de avanzar hacia un gobierno más efectivo, eficiente, participativo, abierto y transparente que fomente el crecimiento inclusivo. Esta ambición se ve subrayada por el hecho de que Costa Rica fue el primer país en firmar un "pacto nacional" para alcanzar los Objetivos de Desarrollo Sostenible (ODS) en 2016. Aunque el país se enfrenta a un creciente déficit fiscal, Costa Rica asignó una mayor proporción de recursos presupuestarios para 2016 a los sectores relacionados con los ODS (desarrollo humano, inclusión social, infraestructura, medio ambiente, energía, océanos y uso de la tierra).

Los ODS se integraron en el PND 2015-2018, en el que la rama ejecutiva delineó programas y asignó recursos para cada uno de los ODS y sus instituciones de implementación. Dentro de este plan, se identificaron tres prioridades:

- Combatir la pobreza;

- Lograr una producción y consumo más sostenibles; y

- Construir infraestructuras resilientes y comunidades sostenibles. ${ }^{11}$

La Estrategia Nacional de Cambio Climático (ENCC) promueve acciones contra el cambio climático y ha de ser implementada a través de la participación ciudadana, la innovación, la investigación, los cambios tecnológicos y el conocimiento para respaldar la seguridad humana y la competitividad (NDC 2017). El objetivo general de Costa Rica es conseguir un 100 por ciento de energía renovable para 2030 (NDC 207).

El informe de 2018 Doing Business indica que Costa Rica ocupa el lugar 61 entre 190 economías. En términos de acceso al crédito ${ }^{12}$, la economía puntúa con un 7.0 (sobre 8) en el índice sobre de profundidad de la información crediticia y una puntuación de 10.0 (sobre 12) sobre la fortaleza del índice de derechos legales (Banco Mundial 2016). ${ }^{13}$ Costa Rica tiene un pobre desempeño en la protección de los inversores minoritarios con un puesto de 165 entre 190 economías (Banco Mundial 2018). El Foro Económico Mundial (2018) clasificó su burocracia gubernamental como "ineficiente", indicó que los factores "suministro inadecuado de infraestructura", "tasas impositivas" y "acceso a la financiación" son los más problemáticos para hacer negocios en Costa Rica. A nivel mundial, Costa Rica se encuentra en el número 52 del ranking de países en facilidad de registrar propiedades (Banco Mundial 2016). La corrupción es un problema importante en Costa Rica, el país ocupa el lugar 59 entre 176 países en el Índice de Percepción de la Corrupción 2017 (Transparencia Internacional 2018). ${ }^{14}$

\footnotetext{
${ }^{11} \mathrm{https} / / /$ sustainabledevelopment.un.org/memberstates/costarica

12 El indicador de acceso al crédito explora "la Fortaleza de los sistemas de reporte crediticio y la efectividad de las leyes sobre colaterales y bancarrota en facilitar préstamos".

${ }^{13}$ Las puntuaciones más altas indican más información crediticia y derechos legales más fuertes para los prestatarios y prestamistas.

${ }^{14}$ El IPC está en una escala de 100 (muy limpio) a 0 (altamente corrupto).
} 


\subsection{Contexto de las finanzas para el desarrollo}

Los factores que han propiciado el éxito económico de Costa Rica son el comercio abierto y la inversión directa extranjera (IDE), que constituyen una parte integral de su modelo de crecimiento (OCDE 2018).

Las fuertes entradas de IDE (ver Gráfico 1), favorecidas por una población educada y un régimen favorable a la IDE, han impulsado la transformación estructural de Costa Rica de una economía rural y agrícola a una estructura más diversificada e integrada en las cadenas de valor mundiales. ${ }^{15}$ Aunque Costa Rica fue severamente golpeada por la crisis financiera mundial en 2008-09, la recesión fue de corta duración, ya que el crecimiento se recuperó rápidamente alcanzando casi un 5\% en 2010-12, debido a fuertes flujos de IDE, particularmente en manufacturas de alta tecnología, conocimiento y servicios (OCDE 2018). En Costa Rica, existe una tendencia a que las empresas orientadas a la exportación sean dinámicas e innovadoras debido a la entrada de IDE y vínculos bien desarrollados con las cadenas de valor mundiales, mientras que las empresas nacionales se centran más bien en actividades de bajo valor agregado. Para estos productos de bajo valor agregado, las empresas nacionales a menudo emplean a trabajadores no cualificados que operan en la economía informal. La economía informal representa el $40 \%$ del empleo total. Aunque el país se benefició de altos niveles de entradas de IDE, las externalidades a firmas locales han sido relativamente insignificantes y el crecimiento general de la productividad del país se ha mantenido limitado (OCDE 2016).

\subsubsection{Costa Rica como receptor y proveedor de AOD}

En 2016, el país recibió una AOD ${ }^{16}$ bruta de 127 millones de dólares estadounidenses ${ }^{17}$ proporcionado por países del CAD y no pertenecientes al CAD, así como a organizaciones multilaterales. Los principales proveedores de AOD fueron Japón (43\% del total de AOD), Alemania (31\%) y la Unión Europea (21\%). Entre 2012 y 2016, el país ha recibido un promedio de 91.5 millones de dólares estadounidenses en AOD por año. ${ }^{18}$ Sin embargo, los flujos de AOD a Costa Rica mostraron una trayectoria creciente y entre 2012 y 2016 aumentaron de 57.2 a 127.4 millones de dólares estadounidenses en términos reales en ese periodo.

En términos de Otros Flujos Oficiales (OOF) ${ }^{19}$ Costa Rica recibió 182.2 millones de dólares estadounidenses en 2012 y 371.8 millones de dólares estadounidenses en $2016^{20}$, la mayoría de los cuales provino del Banco Internacional para la Reconstrucción y Fomento (45\%) y del Banco Inter-Americano de Desarrollo (42\%). Costa Rica también recibe financiación con apoyo oficial en forma de créditos a la exportación con apoyo oficial variable (ver Tabla 2) y que en 2016 ascendió a 6.3 millones de dólares estadounidenses.

\footnotetext{
${ }^{15}$ Ibid.

${ }^{16}$ En este informe, el término AOD se refiere a la AOD bilateral y las salidas concesionales de las organizaciones multilaterales.

${ }^{17}$ En los desembolsos, los precios de 2016 de todos los DAC, no DAC y multilaterales que reportan al Sistema de Reporte de Acreedores del DAC de la OCDE están disponibles en: https://stats.oecd.org/index.aspx?DataSetCode=CRS1

${ }^{18}$ Base de datos del Sistema de Reporte de Acreedores del CAD de la OCDE.

${ }^{19} \mathrm{OOF}$ incluye tanto OOF bilaterales como salidas no concesionales de organizaciones multilaterales.
} 
Tabla 2. Finanzas de desarrollo oficial y créditos de exportación con apoyo oficial a Costa Rica

\begin{tabular}{lccccc}
\hline $\begin{array}{c}\text { Tipo de flujo } \\
\text { (millones USD) }\end{array}$ & 2012 & 2013 & 2014 & 2015 & 2016 \\
\hline AOD & 57.2 & 66.6 & 78.5 & 144.5 & 127.4 \\
OOF & 182.2 & 215.8 & 422 & 309 & 371.8 \\
Créditos a la & 5.9 & 2.2 & 50.5 & 124.2 & 6.3 \\
$\begin{array}{l}\text { exportación con } \\
\text { apoyo oficial }\end{array}$ & & & & & \\
\hline
\end{tabular}

Nota: Desembolsos brutos, precios de 2016, de todos los países del CAD, proveedores no pertenecientes al CAD e instituciones multilaterales/

Fuente: OECD (n.d.[1]), Creditor Reporting System, https://stats.oecd.org/

Costa Rica también recibe financiación para el desarrollo de proveedores emergentes. De acuerdo con AidDATA, los desembolsos de financiamiento oficial para el desarrollo de la república popular de China ascendieron a 892 millones de dólares en 2014, incluidos 395 millones en flujos similares a la AOD, 397 millones de flujos similares a OOF (Otros Flujos Oficiales, por sus siglas en inglés) millones de flujos indeterminados de financiación oficial (Aid Data 2018).

En las entrevistas con la administración se ha puesto de manifiesto que Costa Rica desearía mejorar la transparencia y rendición de cuentas de los recursos recibidos de cooperantes bilaterales y multilaterales. En general los cooperantes no se ajustan a los formatos de reporte nacionales, y no desglosan la información financiera que proveen al país (especialmente en lo que se refiere a cooperación técnica). Anteriormente, existía una mesa de donantes liderada por Costa Rica con sus cooperantes para coordinar sus actividades, aunque esta mesa ya no está operativa. La opacidad en el uso de los recursos externos asignados para Costa Rica provoca a su vez dificultadas para las cuentas nacionales.

Costa Rica es un proveedor y receptor de la cooperación para el desarrollo. En 2015, Costa Rica canalizó 10 millones de dólares estadounidenses a través de organizaciones multilaterales. ${ }^{21}$ En 2014, el financiamiento concesional total de Costa Rica para el desarrollo alcanzó 24 millones de dólares. ${ }^{22}$ Estas cifras corresponden a las contribuciones a organismos multilaterales (que Costa Rica no considera sean homologables a la ayuda oficial al desarrollo). Además, Costa Rica proporciona cooperación técnica (no reembolsable) a países de igual o similar nivel de desarrollo con el financiamiento de fuentes bilaterales y multilaterales y a través de las modalidades de la cooperación Sur-Sur y triangular. Finalmente, Costa Rica también proporciona ayuda a refugiados y migrantes (de Nicaragua y la República Bolivariana de Venezuela ["Venezuela"] principalmente) aunque el país no proporcionó datos o estimaciones sobre los costes de este apoyo. Una estimación de los flujos que Costa Rica proporciona como proveedor en base a los datos disponibles se encuentra en el anexo D.

\footnotetext{
${ }^{21}$ La diferencia entre las estimaciones para 2014 y 2015 se debe a un ajuste en las estimaciones de la OCDE de las contribuciones de Costa Rica a las organizaciones multilaterales. Las estimaciones para 2015 se basan en información adicional recibida del Tesoro del gobierno de Costa Rica.

${ }^{22}$ Estimaciones de la OCDE basadas en el Gobierno de Costa Rica, 2014, 2015; y sitios web de organizaciones multilaterales.
} 


\subsubsection{Flujos no-oficiales a Costa Rica}

Los resultados de la encuesta del CAD sobre movilización de 2015 mostraron que, entre 2012 y 2015, Costa Rica recibió financiación movilizada del sector privado por un total de 708.5 millones de dólares o un promedio de aproximadamente 177 millones por año. $^{23}$

Actualmente, Costa Rica tiene acuerdos de libre comercio (TLC) con China, Singapur y Corea del Sur. ${ }^{24}$ Además, el país implementó el Tratado de Libre Comercio de Centroamérica y República Dominicana (DR CAFTA) en 2009. Costa Rica también es miembro del TLC entre el Sistema de Integración Centroamericano (al cual pertenece Costa Rica) y la UE, que está en vigor desde octubre de $2013 .{ }^{25}$ Como en años anteriores, Costa Rica continuará beneficiándose durante 2014-2020 del programa subregional de la UE para América Central (120 millones de euros). ${ }^{26}$

De acuerdo con las estadísticas del UNCTAD, los flujos de IDE en Costa Rica alcanzaron 2.540 millones de dólares estadounidenses en 2016 y 3.000 millones en 2017. En términos de origen geográfico de los flujos de IDE, en $2012,{ }^{27}$ los mayores inversores en Costa Rica fueron los Estados Unidos (1.051 millones de dólares), México (346 millones de dólares) y España (318 millones de dólares). En términos de stock de IDE, los países más importantes fueron los Estados Unidos (11.513 millones de dólares), España (1.359 millones de dólares) y el Reino Unido (902 millones de dólares) ${ }^{28}$.

\footnotetext{
${ }^{23} 76.5$ millones de dólares a través de garantías, 4.7 millones a través de líneas de crédito, 619 millones a través de préstamos sindicados, 5.8 millones a través de inversiones directas en empresas y 2.4 millones a través de acciones en Vehículos de Inversión Colectiva. Ver Benn, J., et al. (2016), "Amounts Mobilised from the Private Sector by Official Development Finance Interventions: Guarantees, syndicated loans and shares in collective investment vehicles", OECD Development Co-operation Working Papers, No. 26, OECD Publishing, Paris, https://doi.org/10.1787/5jm3xh459n37-en.

${ }^{24}$ EIU (2018): Country Report July 2018: Costa Rica, https://store.eiu.com/product/country-report/costa-rica

${ }^{25}$ EIU (2018): Country Report July 2018: Costa Rica, https://store.eiu.com/product/country-report/costa-rica

${ }^{26}$ European Commission (2018): International Cooperation and Development: Costa Rica, https://ec.europa.eu/europeaid/countries/costa-rica_en

${ }^{27}$ Los datos más recientes sobre los flujos de IDE desglosados por país de origen según las estadísticas de la UNCTAD se refieren a 2012 .

${ }^{28}$ Véase por ejemplo https://unctad.org/en/Pages/DIAE/FDI\%20Statistics/FDI-Statistics-Bilateral.aspx
} 
Gráfico 1. Entradas netas de IDE

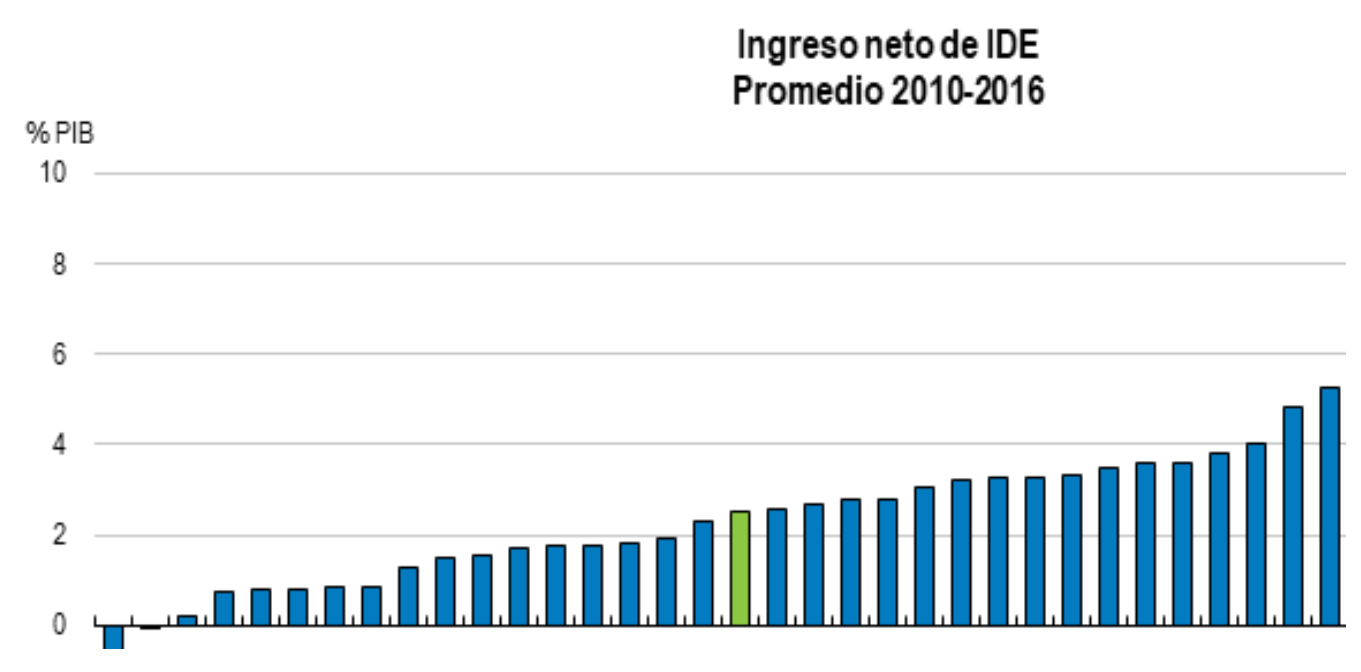

Fuente: OECD (2016), Encuesta de la OCDE en Costa Rica (2016), Paris, OCDE, https://doi.org/10.1787/eco_surveys-cri-2016-en.

De acuerdo con el "Informe de Clima de Inversión 2018" del Departamento de Estado de los Estados Unidos, los sectores de alta tecnología y turismo de Costa Rica son los principales polos de atracción de IDE en el país. Costa Rica atrae a fabricantes de tecnología relativamente avanzada, como fabricantes de dispositivos médicos y compañías de servicios que requieren de mano de obra cualificada.

Costa Rica es también receptor de remesas. Según los datos del Banco Mundial en 2017, Costa Rica recibió el equivalente de 442 millones de dólares estadounidenses en transferencias personales (Banco Mundial 2017).

Finalmente, los flujos financieros ilícitos constituyen una preocupación importante para Costa Rica. Según el informe de Global Financial Integrity. durante 2005 y 2014, las salidas ilícitas totales y las entradas ilícitas totales representaron respectivamente del $34 \%$ al $52 \%$ para las exportaciones y del $4 \%$ - 5\% de las importaciones de Costa Rica (Global Financial Integrity 2017). 


\section{Parte III. Perspectivas de Costa Rica sobre las instrucciones de reporte preliminares}

Esta parte del informe presenta las perspectivas y comentarios de los actores entrevistados en Costa Rica sobre las Instrucciones Preliminares de Reporte de TOSSD. El texto sigue en gran medida la estructura de estas Instrucciones, tal y como estaban desarrolladas en el momento del estudio piloto, aunque algunas secciones se agruparon para evitar la repetición de ideas. Los comentarios de los actores de Costa Rica se han insertado después de los párrafos pertinentes para que los lectores comprendan el contexto en el que se hicieron estos comentarios. Para este estudio piloto, se utilizó la versión 1.0 de las Instrucciones de Reporte de 12 de julio de 2018. 


\section{Preámbulo de las instrucciones de reporte, principales conceptos y definiciones}

\subsection{La definición del TOSSD}

La métrica estadística del Apoyo Oficial Total al Desarrollo Sostenible (TOSSD) incluye el conjunto de los flujos de recursos con apoyo oficial para promover el desarrollo sostenible en los países en desarrollo y para apoyar a los habilitadores de desarrollo o afrontar los desafíos globales a nivel regional o mundial.

Sobre el preámbulo, solo se recibió un comentario, a saber, que aquellos actores que vayan a reportar TOSSD se comprometan con los principios de rendición de cuentas y midan el impacto de sus actividades.

Todos los actores entrevistados consideraron que la definición del TOSSD era clara.

Algunos actores sugirieron simplificaciones a nivel lingüístico para las directivas en castellano. Por ejemplo, se propuso hablar de 'estadística de TOSSD' y no de 'métrica estadística de TOSSD'. Así mismo se propuso hablar de 'cooperación total al desarrollo sostenible' y no de 'apoyo oficial total al desarrollo sostenible' que tiene una connotación Norte-Sur que no captura la horizontalidad y multi-direccionalidad de la cooperación Sur-Sur y Triangular. Así mismo, el concepto de 'habilitadores del desarrollo' se considera abstracto y sería útil utilizar una nomenclatura que enfatizara la dimensión de 'impacto global'.

Además, se realizaron algunas clarificaciones al respecto de la definición:

- El pago de la deuda supone una reducción de flujos de TOSSD neto hacia el país deudor. El pago inicial, si entra en el marco de TOSSD, puede haber contribuido al desarrollo sostenible para el país receptor de la deuda y los pagos serán descontados de los flujos TOSSD del deudor.

Se proporcionaron además ciertas sugerencias:

- El marco debe incluir los aportes nacionales que complementa los aportes externos (contrapartida), también para flujos de cooperación técnica (y que a veces son mayores que los flujos externos proporcionados a Costa Rica).

- TOSSD debe incluir flujos privados que sean apoyados por financiación pública incluido el apoyo técnico no reembolsable proporcionado en esquemas con el sector privado.

- La definición debe especificar que flujos de recursos incluye tanto entradas como salidas. 


\subsubsection{Desarrollo sostenible}

El concepto de "desarrollo sostenible" se define como aquel desarrollo que satisface las necesidades del presente sin comprometer la capacidad de las futuras generaciones de satisfacer sus propias necesidades. ${ }^{29}$

El "desarrollo sostenible" en el contexto del TOSSD está ligado intrínsecamente a los Objetivos de Desarrollo Sostenible acordados en la Agenda $2030^{30} .{ }^{31}$ Las actividades registradas como parte del TOSSD apoyan la implementación de los ODS a través de la generación de crecimiento económico sostenible, garantizando la inclusión social, sin comprometer el medio ambiente. En el momento en que la Agenda 2030 se dé por concluida y sea sustituida por otro marco, la métrica del TOSSD se actualizará para vincularla con dicho marco.

Costa Rica apoya la definición propuesta de desarrollo sostenible para TOSSD, considerando que es amplia y que está lo suficientemente consensuada a nivel internacional. Sin embargo, en las entrevistas con los interlocutores locales quedó constancia que este marco definitorio es también demasiado impreciso y puede ser poco operacional en el contexto de Costa Rica, donde el desarrollo sostenible ha sido un pilar fundamental en su estrategia de desarrollo desde hace varias décadas. Es más, el desarrollo sostenible es un marco que permea toda la acción de las instituciones públicas en Costa Rica - aunque lógicamente existan conflictos propios entre instituciones sobre cómo y cuándo priorizar una dimensión del desarrollo sostenible sobre otra, por ejemplo, en temas de seguridad alimentaria. Esta acción incluye los acuerdos internacionales y de comercio a los que Costa Rica se adhiere y también al sector privado, tanto nacional como internacional, que tiene que cumplir con una legislación relativamente estricta en materias social y ambiental. Costa Rica, de hecho, busca atraer este tipo de inversión extranjera.

Se puso de manifiesto lo siguiente:

- La definición podría hacer referencia a los principios del que contamina paga y por lo tanto del deber de los países que han contaminado más a pagar más para asegurar un marco global para el desarrollo sostenible de todos.

- Costa Rica considera que las inversiones que no sean sostenibles no deben incluirse en TOSSD. Cuando hubo inversiones 'marrones', Costa Rica tendió a no aprobarlas ya que cualquier proyecto exterior o interior debe estar alineado con el Plan Nacional para el Desarrollo (PND), donde la sostenibilidad es central. El nuevo PND para 2019-2022 fue presentado a la par que el Plan de Inversiones Públicas (PNDIP) y estará guiado por los ODS, reforzando por tanto la dimensión de sostenibilidad en Costa Rica.

\footnotetext{
${ }^{29}$ Definición utilizada por primera vez en el Informe Brundtland. (Ver Report of the World Commission on Environment and Development: Our Common Future", Capítulo 2 "Towards Sustainable Development”, p. 41 (New York: UN, 1987). Contiene dos conceptos clave: i) el concepto de "necesidades", en particular las necesidades esenciales de los pobres del mundo, a las que se debe dar prioridad absoluta; y ii) la idea de las limitaciones impuestas por el estado de la tecnología y la organización social sobre la capacidad del medio ambiente para satisfacer las necesidades presentes y futuras.

${ }^{30}$ Ver "Transforming our world: the 2030 Agenda for Sustainable Development": https://sustainabledevelopment.un.org/post2015/transformingourworld

${ }_{31}$ Tener en cuenta los vínculos con los marcos de desarrollo sostenible establecidos a nivel regional, p. por la Comisión de la Unión Africana. Ver https://au.int/en/agenda2063.
} 
- También se mencionó la necesidad de asegurarse que haya una metodología para aislar la parte 'marrón' de la AOD y sólo incluir la parte 'verde' de la AOD en el TOSSD.

- El TOSSD debe ser reportado a nivel meta de los ODS ya que hay riesgo de ser impreciso si se liga a objetivos. Debe reconocerse la interseccionalidad entre metas y objetivos para evitar que los datos de TOSSD no acaben siendo analizados en silos por sectores de actividad. En particular, se mencionó la dificultad de recoger casos en que una inversión que favorezca un ODS vaya en contra de otro ODS. Como ejemplo de actividad que podría apoyar un objetivo e impactar negativamente en otro, se describe el construir una central geotérmica en una zona protegida de un volcán.

- TOSSD debe ser ligado a la Agenda 2030 y ser actualizado una vez se reemplace ésta por otro marco en el 2030.

- Costa Rica sostiene que el ingreso per cápita no puede ser el único indicador del nivel de desarrollo o de la necesidad de financiación externa de un país.

- A nivel regional, Costa Rica participa en el Sistema de Integración Centroamericana (SICA) donde tiende a despuntar en términos de regulación ambiental. Sería importante que TOSSD sea ligado a la Agenda 2030 que es universal y que por tanto debería aplicarse a todos los países de la región. Además, TOSSD debería establecer criterios a nivel regional para así incentivar una 'carrera hacia la cima' por parte de esta región y, si posible, a nivel subregional ya que tiene poco sentido que Costa Rica se compare únicamente a toda América Latina y el Caribe, teniendo más sentido una categorización a nivel centroamericano.

- El establecimiento de criterios de sostenibilidad para operacionalizar esta definición (por ejemplo, de biodiversidad, estándares de emisiones, huella ambiental, etc.) debería ser una labor que las regiones o incluso las sub-regiones deberían acometer. Esto permitiría que TOSSD se apoyase sobre las peculiaridades de cada región. La CEPAL podría facilitar este proceso a nivel de América Latina y el Caribe, por ejemplo, apoyándose en ejercicios realizados anteriormente como la Iniciativa de las Finanzas para la Biodiversidad (ver cuadro 1). 


\section{Cuadro 1. La Iniciativa de las Finanzas para la Biodiversidad (BIOFIN)}

BIOFIN es un programa de 15 millones de dólares estadounidenses implementado por el Programa de las Naciones Unidas para el Desarrollo (PNUD), con el apoyo financiero de la Unión Europea (UE), Alemania y Suiza. BIOFIN está trabajando con los países socios, incluida Costa Rica, para ayudarlos en la movilización nacional de recursos a través de la elaboración de estrategias para la biodiversidad y servicios del ecosistema. El PNUD ha desarrollado una metodología, llamada "Cuaderno de trabajo BIOFIN", que incluye una revisión de los marcos políticos, institucionales y fiscales actuales que afectan a la biodiversidad y a los servicios de los ecosistemas, así como el impacto, eficacia, alineación y coherencia de las políticas e instituciones públicas en este ámbito. BIOFIN ayuda a los países a identificar las brechas financieras para la biodiversidad y los servicios de los ecosistemas, y evaluar qué mecanismos y políticas podrían usarse para llenarlos a nivel nacional. El programa tiene como objetivo ayudar a los países a financiar sus Estrategias Nacionales de Biodiversidad y Planes de Acción (EPANDB), implementando así el Plan Estratégico para la Biodiversidad 2011-2020 y las veinte Metas de Aichi a nivel nacional. BIOFIN se está probando actualmente en 19 países de Asia, África y América Latina, entre estos últimos también está Costa Rica.

Fuente: UNDP (United Nations Development Programme) (2014), The Biodiversity Finance Initiative - An overview and key progress summary, information document, UNEP/CBD/WGRI/5/INF/13, 10 June 2014, and UNDP (2013b), "Transforming Biodiversity Finance: The Biodiversity Finance (BIOFIN) Workbook for assessing and mobilizing financial resources to achieve the Aichi Targets and to implement National Biodiversity Strategies and Action Plans", Version 3.0 Draft for Distribution, June 4, 2013

\subsubsection{Flujos de recursos}

El término "recursos" contenido en la definición del TOSSD abarca tanto a los recursos técnicos como a los financieros. ${ }^{32}$

Para Costa Rica la definición de flujos de recursos está clara. Costa Rica, siendo proveedor 'dual', considera muy importante la inclusión de la cooperación técnica, que debe ser entendida de manera amplia, incluyendo actividades como: los intercambios de experiencias, tecnología u otros recursos, gestión del conocimiento, actividades de formación, capacitación o sensibilización.

${ }^{32}$ La AAAA considera que la cooperación internacional para apoyar la implementación de la Agenda 2030 incluye tanto recursos técnicos como financieros.Véase http://www.un.org/esa/ffd/wp-content/uploads/2015/08/AAAA_Outcome.pdf . 


\subsubsection{Con apoyo oficial}

En el contexto del TOSSD, los "recursos con apoyo oficial" se definen como:

a) recursos aportados por:

i) agencias oficiales, incluidos los gobiernos estatales y locales, o por sus agencias ejecutivas.

ii) empresas de titularidad pública y empresas bajo control gubernamental ${ }^{33}, y$

iii) otras empresas bajo influencia significativa del gobierno ${ }^{34}$.

b) recursos privados movilizados por intervenciones oficiales, donde puede demostrarse un nexo causal directo entre la intervención oficial y los recursos privados.

Costa Rica considera que esta definición es lo suficientemente amplia y adecuada para recoger todas las iniciativas. En Costa Rica no existe institución alguna que recoja datos sobre financiación privada movilizada con fondos públicos, aunque sería útil tener esta información en el futuro. Alguna información podría ser recogida por diferentes instituciones (por ejemplo, el Banco Central, Hacienda o MIDEPLAN) pero la información estaría fragmentada. Costa Rica no tiene empresas bajo influencia significativa del gobierno (sólo empresas públicas o privadas).

El ejemplo más claro de iniciativa donde podrían haberse apalancado recursos es un fideicomiso ambiental que surgió tras una operación de canje de deuda de EEUU. Se pregunta si podrían considerarse como flujos privados movilizados por EEUU.

\subsection{Un enfoque fundamentado en dos pilares}

El TOSSD es un marco sustentado en dos pilares para el seguimiento de los siguientes recursos con apoyo oficial: i) los flujos transfronterizos de recursos hacia los países en desarrollo y ii) la financiación para los habilitadores de desarrollo y los desafíos globales a nivel regional y mundial [la agenda de los bienes públicos globales], tal y como ilustra el Gráfico 2.

\footnotetext{
${ }^{33}$ Empresas sobre las cuales el gobierno se asegura el control mediante la posesión de más de la mitad de los títulos valores con derecho a voto o, en su defecto, controlando más de la mitad de los derechos de voto de los tenedores de acciones, o a través de una legislación que faculte al gobierno para determinar la política corporativa o designar a los directores.

${ }^{34}$ Esta categoría se incluye para reconocer la capacidad del gobierno para ejercer influencia de formas muy diversas más allá del mero control de una compañía a través de los derechos de voto (véase, por ejemplo, el capítulo 6, sección B del Manual de balanza de pagos y posición de inversión internacional del FMI Sexta edición, BPM6). El objetivo del TOSSD es capturar la totalidad de las intervenciones oficiales pero, dada la variedad de países que reportan, la decisión sobre la inclusión de empresas bajo influencia significativa del gobierno se deja en última instancia a la discreción del país que reporta.
} 
Gráfico 2. El marco de medición estadística del TOSSD se sustenta en dos pilares

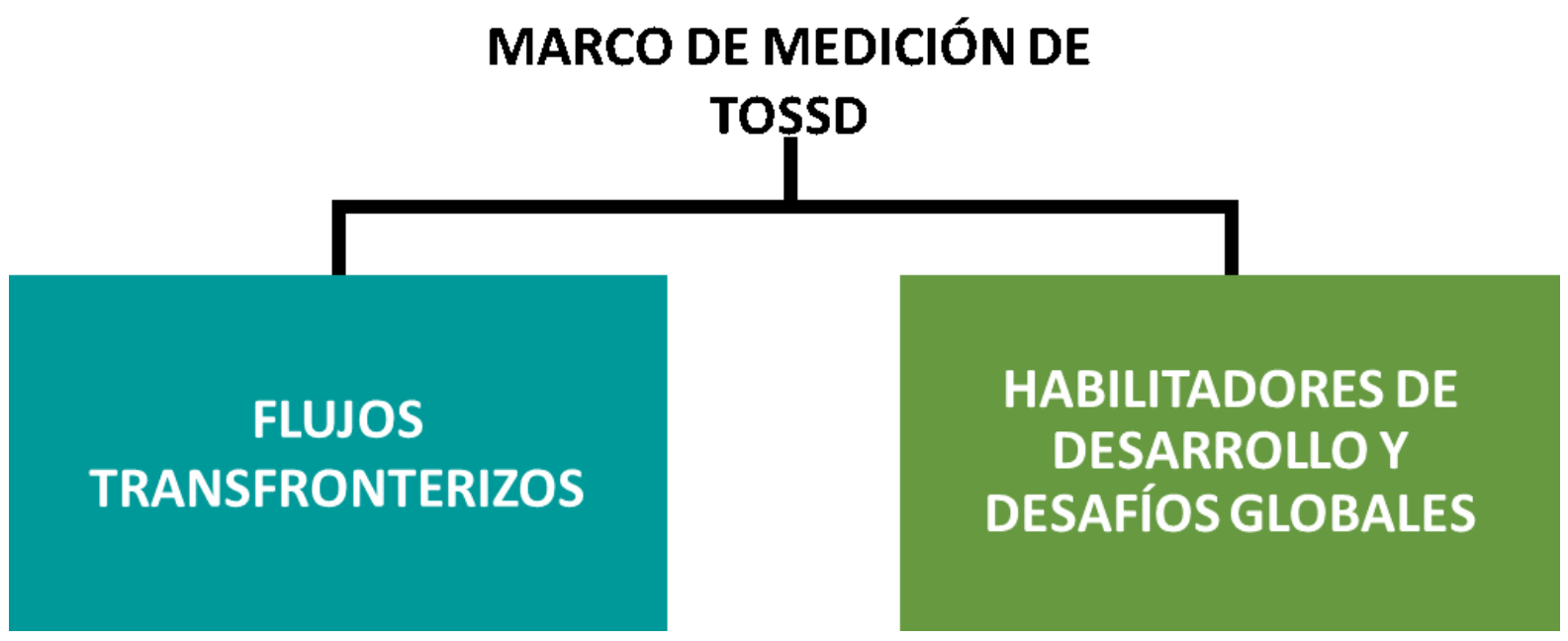

Para la mayoría de los actores entrevistados, la distinción entre dos pilares no siempre quedó clara y, para algunos actores, resulta compleja:

- El ámbito del primer pilar se entiende mejor que el del segundo pilar, quedando claro una vez que se explica que los flujos que quedarían registrados bajo este pilar se basa en los principios de la balanza de pagos de 'residentes' y 'no residentes'. Hay confusión lingüística (en castellano) sobre el concepto de 'flujos transfronterizos', ya que estos designan operaciones entre países con fronteras terrestres compartidas (ej. Costa Rica y Nicaragua o Costa Rica y Panamá). Se recomienda cambiar la denominación de este pilar para pasar a llamarse 'flujos externos para el desarrollo'. Las personas entrevistadas consideran el alivio de la deuda, las becas y la Cooperación Sur-Sur podrían incluirse en el primer pilar.

- El segundo pilar es más difícil de definir y conceptualizar:

- El concepto de habilitadores del desarrollo es confuso, y lo que algunos actores ven como habilitador, otros ven como flujo transfronterizo (ej. una carretera entre países, un parque que mejora la biodiversidad local y global). Para algunos actores, aquí se podrían incluir todas las contribuciones que ayuden a alcanzar los ODS, siendo demasiado impreciso. Es más, en algunos casos se argumenta que el segundo pilar corre el riesgo de acabar siendo una suerte de categoría 'cajón desastre' donde todo lo que no entre en el primero acabaría en el segundo por defecto.

- Algunas actividades tienen un carácter marcadamente global, como serían las actividades de mantenimiento de la paz, el apoyo a refugiados o migrantes, o la lucha contra el cambio climático. El apoyo a los refugiados y migrantes se considera más bien como un bien público global (puesto que la migración aporta beneficios a los países receptores de migrantes), mientras que el cambio climático es claramente un desafío.

- Otros actores indican la necesidad de un pilar regional en el que se podrían incluir las facilidades transfronterizas para el comercio, inversiones en sistemas de electrificación y carreteras que tengan un carácter sub-regional 
(centroamericano), actividades para la protección de los océanos o de un parque natural colindante - ya que en estos casos no habría transferencias de recursos entre países de la región, pero se estaría potenciando su desarrollo. En este sentido, se preferiría desarrollar un pilar o un sub-pilar que permitiera identificar habilitadores de desarrollo y desafíos regionales. Costa Rica podría considerarse como perteneciente a la región de América Latina y el Caribe, pero sería útil considerar el país también como parte de América Central.

- Asimismo, se pide que se limite la expresión de 'países en desarrollo' que trae consigo la idea de cooperación Norte-Sur. Se prefiere el uso de 'países incluidos en la lista de receptores de TOSSD'.

- Finalmente, se pide para resolver estas dudas que se desarrolle una guía con criterios para clasificar las actividades en estos dos pilares (y llegado el caso, un pilar regional).

\subsection{Principios de reporte}

\subsubsection{Normas de calidad estadística del sistema del TOSSD}

El marco estadístico del TOSSD está sujeto al Marco de Garantía de la Calidad Estadística de las Naciones Unidas. ${ }^{35}$. La gobernanza de la métrica del TOSSD garantizará la calidad del entorno institucional (objetividad, imparcialidad, transparencia y credibilidad), fundamental para generar confianza, que es el verdadero pilar de un sistema estadístico.

Costa Rica considera que la gobernanza de TOSSD debería estar ligada a la ONU. Para asegurarse el mayor apoyo político, se sugiere que se sitúe bajo ECOSOC. Para la parte técnica (por ejemplo, la colecta datos), la OCDE y otras organizaciones regionales, como la CEPAL para América Latina y el Caribe, parecen las más adecuadas.

\subsubsection{Reporte por nivel de actividad}

Todos los flujos de recursos del TOSSD pueden reportarse a nivel de actividad. En algunos casos se permite cierto nivel de agregación para limitar la carga informativa y el volumen de registros.

La mayoría de actores entrevistados no conocían la base de datos de la OCDE $\left(\mathrm{CRS}^{36}\right)$ - siendo así incluso para aquellos actores que trabajan en la cooperación al desarrollo con los miembros del CAD. Así pues, es de esperar que haya que realizar un esfuerzo especial para que los actores relevantes de Costa Rica sepan de la existencia de la base de datos de TOSSD, una vez sea creada ésta.

\subsubsection{Punto de medición}

Los datos sobre los flujos de recursos del TOSSD se reportarán siguiendo el año natural. Se recogerán datos tanto de compromisos como de desembolsos. Un compromiso es una obligación contraída en

\footnotetext{
${ }^{35}$ Ibid.

${ }^{36}$ Disponible en https://stats.oecd.org/Index.aspx?DataSetCode=crs1 
firme por escrito por el proveedor, respaldada por la partida presupuestaria o la disponibilidad de los fondos necesarios, para suministrar unos recursos determinados conforme a unos términos y condiciones financieras concretas y para unos fines específicos en beneficio del destinatario. El compromiso se considera vigente desde la fecha en que se firma el acuerdo financiero o, en su defecto, desde el momento en que se informa sobre la obligación al beneficiario. Un desembolso es la colocación de recursos a disposición del beneficiario.

Las definiciones de "compromiso" y "desembolso" están claras para los actores entrevistados de Costa Rica.

\subsubsection{Moneda}

Los datos del TOSSD se reportan en la moneda en que se realiza la transacción. Sin embargo, para la presentación y difusión de datos consolidados la moneda de referencia es el dólar estadounidense (USD). Los datos reportados en divisas distintas al USD se convertirán a USD utilizando el promedio anual de los tipos de cambio. ${ }^{37}$

Existe una inquietud por cómo se va utilizar el tipo de cambio para pasar de moneda nacional al dólar estadounidense (USD). Se explicó que el Secretariado aplicará el tipo de cambio medio del año para suavizar las fluctuaciones diarias durante el ejercicio.

\subsection{Principales conceptos estadísticos}

\subsubsection{Proveedor y receptor}

Los países proveedores y las instituciones son los principales encargados de la recogida de los datos del TOSSD. Estos datos se complementan con otros procedentes de los países receptores, comunicados con carácter voluntario, en el momento en que sea posible y de acuerdo con sus capacidades. ${ }^{38}$

Para Costa Rica, los países proveedores son los que deben reportar a TOSSD. Costa Rica tiene un rol 'dual' como país proveedor y receptor. Así pues, considera útil tener información de estas dos dimensiones. Aunque se podría utilizar la información de los receptores para la triangulación de datos con los de los proveedores, se considera relativamente complejo hacerlo. Sería necesario establecer un proceso de conciliación de datos cuando haya diferencias entre los datos TOSSD a Costa Rica y datos registrados por Costa Rica en sus sistemas nacionales.

Costa Rica sería capaz de reportar todos los campos del formulario de reporte de TOSSD salvo los fondos privados movilizados que hoy en día no se recogen. En tanto que proveedor de cooperación Sur-Sur, Costa Rica sugiere que se incluyan las categorías de cooperación Sur-Sur estricta (donde hay un flujo financiero no-reembolsable entre proveedor y receptor) y la bi-direccional (donde hay intercambio de flujos financieros no-reembolsables y de conocimientos) en el formulario de reporte.

\footnotetext{
37 Véanse las Estadísticas Financieras Internacionales del FMI, disponibles en: http://data.imf.org/?sk=4C514D48-B6BA49ED-8AB9-52B0C1A0179B.

${ }^{38}$ Los países proveedores y las instituciones deben facilitar la creación de las competencias técnicas en aquellos países en desarrollo que desean establecer sus propios sistemas para reportar y analizar los datos del TOSSD.
} 
Los proveedores bilaterales son países y territorios que disponen de una política de cooperación para el desarrollo y emprenden actividades en apoyo del desarrollo sostenible en terceros países.

Los proveedores multilaterales son agencias, instituciones, organizaciones o fondos internacionales cuyos miembros son gobiernos y que están representados al más alto nivel de toma de decisiones en la institución por personas que actúan no como individuos sino a título oficial.

Los receptores del TOSSD están establecidos en la lista de países y territorios receptores elegibles, pero también incluyen instituciones internacionales.

Costa Rica insistió en que debería incluirse dentro de la definición la categoría de "cooperante dual", para diferenciarlo del concepto de cooperante neto. Costa Rica es un país con un rol dual, receptor de cooperación y proveedor únicamente de cooperación técnica. Aunque también proporciona contribuciones a organismos multilaterales, estas contribuciones se corresponden con las contribuciones obligatorias de membresía. Una parte de la administración, incluidas la Cancillería y MIDEPLAN, no considera que estas contribuciones puedan ser consideradas como cooperación al desarrollo, mientras que otras unidades que se encargan de realizar aportaciones sí lo consideran. Además, Costa Rica apoya a refugiados y migrantes en su territorio, proporciona ayuda humanitaria, contribuye a las operaciones de mantenimiento de la paz, su sistema académico participa en investigación en temas regionales y globales, y tiene costes fijos en la administración de sus actividades de cooperación.

\subsubsection{Vías de canalización}

La vía de canalización es la entidad sobre la que recae la responsabilidad de implementación de la actividad y que suele estar vinculada a la agencia proveedora mediante un contrato o cualquier otro acuerdo vinculante, y que es directamente responsable ante ella. Se trata de un elemento clave del marco del TOSSD dado que ayuda a identificar a la institución responsable de la ejecución de la actividad, lo que resulta fundamental para dar seguimiento a los flujos y mejorar la rendición de cuentas tanto por lo que respecta al proveedor como a los países socios.

Se pide que se clarifique la definición porque no siempre la entidad responsable del uso de los fondos es la que implementa. O bien se clarifica o pueden crearse dos categorías para recoger ambos aspectos (administrador de fondos y responsable de la ejecución de las iniciativas - Proyectos programas, acciones).

\subsubsection{Instrumentos financieros}

Los flujos de recursos del TOSSD son provistos a través de numerosos instrumentos financieros. Estos instrumentos se clasifican como donaciones, instrumentos de deuda, instrumentos de financiación mezzanine, y participaciones y acciones en vehículos de inversión colectiva. También se incluyen instrumentos que generan pasivos contingentes, pero no necesariamente un flujo desde el proveedor al receptor (p. ej. garantías).

No hubo comentarios sobre la definición de los instrumentos financieros. 


\section{Primer pilar del TOSSD: flujos transfronterizos de recursos para apoyar el desarrollo sostenible}

\subsection{Alcance del pilar de los flujos transfronterizos de recursos}

\subsubsection{Categorías que abarcan los flujos de recursos}

El pilar de flujos transfronterizos de recursos abarca los recursos aportados por los proveedores bilaterales y multilaterales a los países receptores elegibles para el TOSSD a fin de apoyar el desarrollo sostenible (Gráfico 4). La principal distinción se produce entre, por una parte, las donaciones y las aportaciones en especie, y, por la otra, las transacciones financieras. No se establecen diferencias entre las transacciones concesionales y las no concesionales. También se incluyen los recursos movilizados desde el sector privado por las intervenciones oficiales. Sin embargo, se presentan en un epígrafe separado ya que los fondos no necesariamente proceden del país del proveedor e incluso pueden ser de origen nacional, esto es, que provengan del país receptor.

Costa Rica no acepta proyectos de cooperación que no sean sostenibles. Para TOSSD, Costa Rica estaría pues relativamente preparada. En TOSSD, no deberían incluirse los siguientes apartados:

- Costes administrativos de oficinas de cooperación al desarrollo con sede en Costa Rica;

- Contribuciones realizadas con una motivación principalmente religiosa ej. Reconstrucción de Iglesias;

- Actividades antiterroristas; y

- Actividades económicas y medioambientales que no estén en línea con el desarrollo sostenible (tal y como marca el Plan Nacional de Desarrollo e Inversiones Públicas) pero que siguen siendo importantes para el desarrollo del país (por ejemplo, se hizo una propuesta para un proyecto de refinería de petróleo en el país que finalmente no se llevó a cabo. Este tipo de iniciativas no deberían incluirse en TOSSD).

TOSSD sí debería incluir los siguientes apartados:

- Programas sociales y culturales orientados hacia el desarrollo (ej. apoyo para eventos deportivos o artísticos, conciertos musicales, etc.);

- Actividades de investigación, ya sea en el país proveedor o en otro lugar;

- Becas/ costes imputados a estudiantes;

- Actividades relacionadas con la paz y la seguridad (ej. operaciones de mantenimiento de la paz);

- Refugiados y migrantes, en particular costes de refugiados y migrantes incurridos dentro del país donante (el país no mantiene una contabilización separada en cuanto a la atención de refugiados y migrantes); y

- Alivio de la deuda. 
Gráfico 3. Perspectiva general del pilar de los flujos transfronterizos de recursos del TOSSD

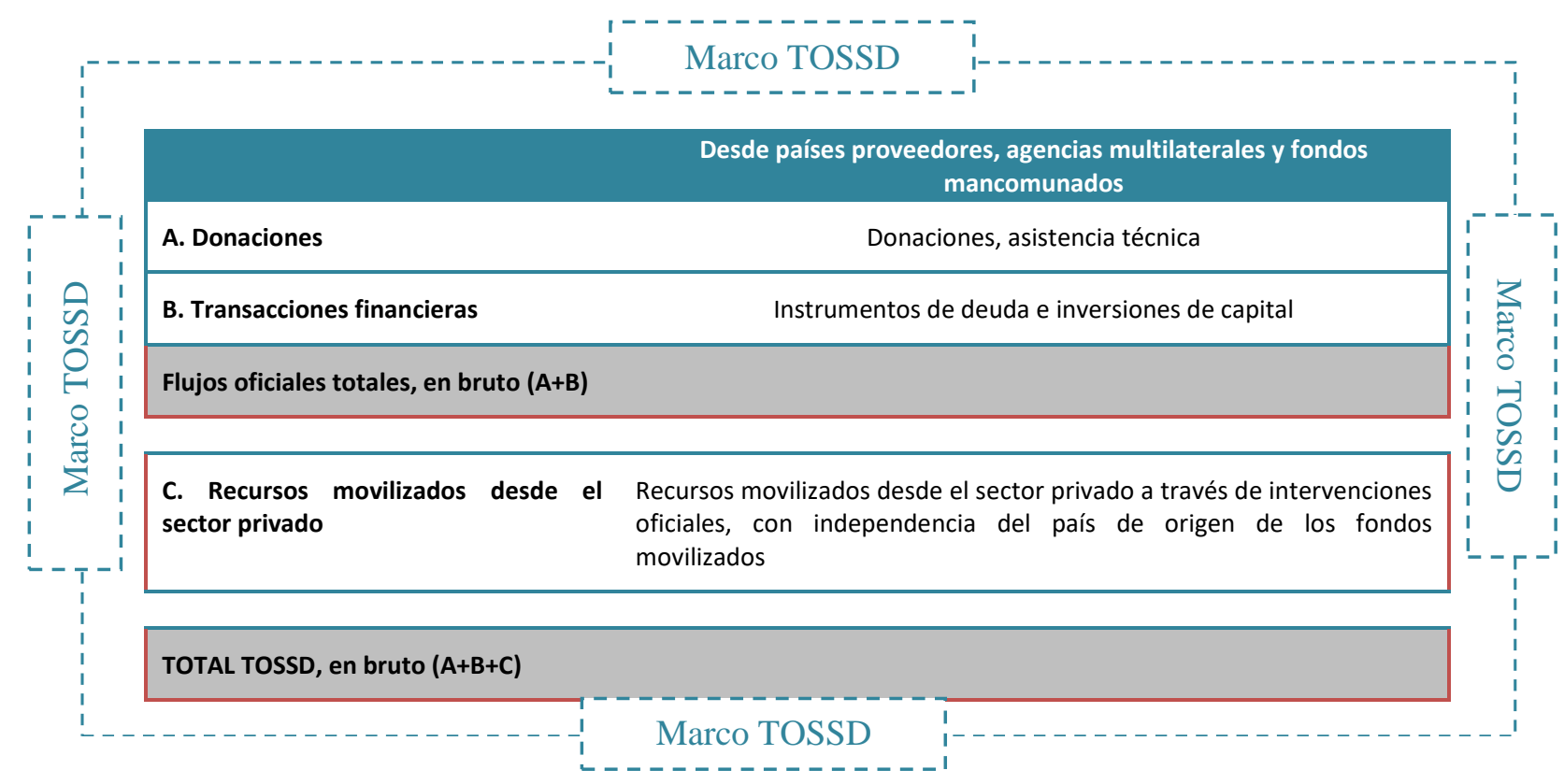

En el sistema del TOSSD, los proveedores bilaterales informan sobre las actividades que emprenden directamente con un país receptor o que financian a través de contribuciones asignadas a un fin específico destinadas a organizaciones multilaterales para intervenciones concretas, normalmente relacionadas con proyectos $(A+B$ en el 


\section{Gráfico 4. Reporte en TOSSD por proveedor}

Los países proveedores reportan A y B. Los proveedores multilaterales reportan C y D.

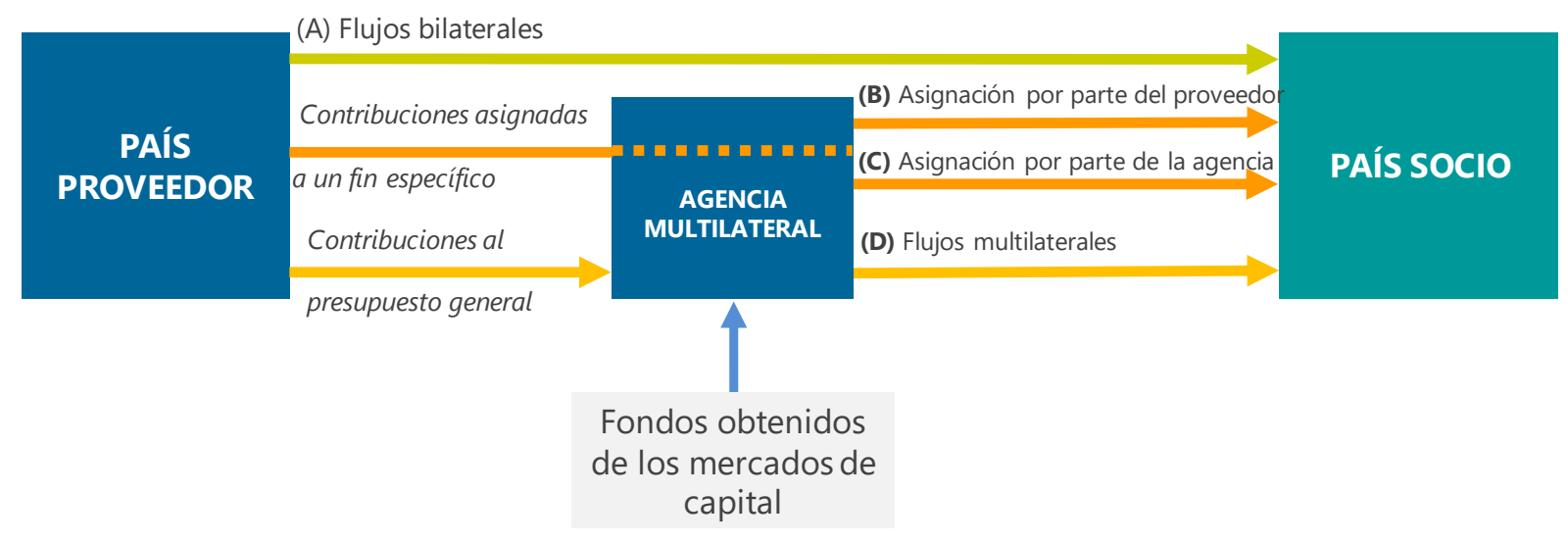

En el sistema del TOSSD, los proveedores multilaterales informan sobre las actividades que emprenden bajo su propia responsabilidad (las propias instituciones toman las decisiones sobre las asignaciones de fondos para fines específicos) ( $C+D$ en el Gráfico 4). En el caso de fondos fiduciarios gestionados por varias organizaciones multilaterales, se deberá estudiar, en función de cada caso, cuál es la institución mejor posicionada para informar sobre los flujos de salida del TOSSD, que normalmente será la institución principal.

Costa Rica no tiene una estrategia para coordinar su trabajo con las organizaciones multilaterales, este trabajo se decide a nivel temático y cada institución utiliza sus propios criterios para decidir la asignación de recursos. La mayor parte del presupuesto, hasta el momento, han sido aportaciones y capitalizaciones obligatorias para pertenecer a una institución. Las decisiones sobre financiación (y por lo tanto pertenencia) a una institución multilateral han de ser aprobadas por un grupo interinstitucional formado por el Ministerio de Relaciones Exteriores y Culto, el Ministerio de Hacienda y el Banco Central, así como por el Congreso de los Diputados.

Aun así, Costa Rica considera que no deberían incluirse en TOSSD las contribuciones asignadas a un fin específico y las contribuciones al presupuesto general de las organizaciones multilaterales.

No hubo comentarios sobre la gestión de fondos fiduciarios. Se considera que la ONU tendría la información necesaria para reportar sobre sus fondos fiduciarios. 


\subsubsection{Vencimiento de las transacciones incluidas}

34. Respecto a los flujos de capital, el alcance del pilar de los flujos transfronterizos de recursos del TOSSD se limita generalmente a las operaciones a largo plazo (esto es, con un vencimiento superior a un año), en consonancia con las estadísticas de balanzas de pagos y los sistemas de cuentas nacionales.

35. También se recogerán datos sobre transacciones financieras a corto plazo de bancos multilaterales de desarrollo destinadas a apoyar el desarrollo sostenible de los países receptores del TOSSD. A fin de evitar la proliferación de registros, estos datos deberán ser reportados a nivel agregado (por país receptor). En las presentaciones de datos del TOSSD, las financiaciones a corto y largo plazo se presentarán por separado.

La mayoría de los flujos de capital que llegan a Costa Rica por parte del sector privado se consideran IDE. La IDE hacia Costa Rica responde al modelo de desarrollo sostenible del país, primando los criterios ambientales y sociales - aunque también aporta estabilidad al sistema cambiario del país, ya que Costa Rica no exporta recursos naturales.

Costa Rica (a través del Banco Central) recoge la financiación oficial a corto plazo, aunque esta financiación sea principalmente facilidades de líneas de crédito para apoyar la actividad operativa del sector privado (principalmente de empresas matrices). Dicha financiación se usaría para apoyar la gestión de la tesorería - y por ende los empleos y la actividad económica del país, y por lo tanto apoyaría al desarrollo sostenible de las empresas y del país. Por ello se considera que debería formar parte de TOSSD. La mayoría de la financiación es sin embargo a más largo plazo.

\subsection{Criterios específicos de elegibilidad}

\subsubsection{Criterios de elegibilidad con respecto al desarrollo sostenible}

En el contexto del TOSSD, se considera que una actividad apoya el desarrollo sostenible si contribuye de forma directa al menos a una de las metas de los ODS, según la definición de las mismas contenida en la lista oficial ${ }^{39}$ de metas de los ODS elaborada y mantenida por la Comisión de Estadística de las Naciones Unidas (CENU).

Se puede dar la situación de que los encargados del reporte no encuentren ningún vínculo directo con ninguna de las metas de los ODS. En estos casos, la entidad informante podrá reportar dicha actividad vinculándola a un objetivo y aportando una justificación adecuada en el campo relevante del formulario de reporte a nivel de actividad del TOSSD.

Los criterios de elegibilidad deben ser articulados al nivel metas, mejor que al nivel objetivos, puesto que el mapeo a nivel objetivos es demasiado vago.

Las actividades promovidas por cooperantes que no estén alineadas con el Plan Nacional de Desarrollo e Inversiones Públicas sólo podrán ser aprobadas por criterios políticos y no son frecuentes. La mayoría de los cooperantes que operan en Costa Rica realizan propuestas de proyectos alineados con el Plan y son por lo tanto sostenibles. Algunos cooperantes, de

\footnotetext{
${ }^{39} \mathrm{https}$ ://unstats.un.org/sdgs/indicators/indicators-list/
} 
hecho, están volcados principalmente en apoyar Costa Rica a alinear su Plan y su implementación con los ODS. Se recomienda, sin embargo, redoblar estos esfuerzos y asegurarse que todos los actores gubernamentales cuenten con una guía para apoyarles en el alineamiento institucional con la Agenda 2030. En caso de contradicción entre metas de los ODS, se recomienda primar la legislación nacional y, en su defecto, usar la Agenda 2030 como marco, para determinar si una actividad debe seguir adelante o no, y si se puede contabilizar en TOSSD o no.

\subsubsection{Países elegibles para el TOSSD}

Para que una actividad se considere parte del TOSSD, esta deberá suponer un flujo transfronterizo de recursos a un país incluido en la Lista de países receptores del TOSSD. Para cualquier año de referencia, esta Lista incluye:

i. Todos los países y territorios que están incluidos en la "Lista del CAD de países y territorios beneficiarios de $A O D$ " 40 .

ii. Otros países y territorios que han activado el procedimiento de adhesión del TOSSD.

Cualquier país o territorio puede activar el procedimiento de adhesión en cualquier momento. El procedimiento es voluntario, pero debe incluir una justificación motivada conforme al contexto económico, social o medioambiental específico que afronta el país. Se espera que los donantes tradicionales no utilicen el procedimiento de adhesión del TOSSD.

Para Costa Rica, no habría sensibilidades en aplicar al procedimiento de adhesión si el país saliese de la lista de países receptores de AOD. La graduación de la AOD es un tema sensible en Costa Rica, aunque haya poco conocimiento sobre el proceso y los criterios que se usan para dicha graduación, así como los vínculos (inexistentes) entre graduación y el proceso de adhesión a la OCDE que está actualmente en marcha en Costa Rica. Los criterios que se utilizan en el Comité de Ayuda al Desarrollo para la decisión de la graduación de la AOD responden al nivel de ingreso (marcado por el Banco Mundial). Los Países Menos Adelantados (PMAs) de acuerdo con la categorización de Naciones Unidas también están incluidos.

\subsection{Métodos específicos}

\subsubsection{Medición de la cooperación técnica}

La implementación de actividades de cooperación técnica puede requerir la contratación de expertos o consultores en los mercados internacionales, o el uso de funcionarios públicos de los países proveedores. En el primer caso, el TOSSD registra los gastos incurridos por el proveedor dado que estos son gastos comparables internacionalmente en términos monetarios; en el segundo caso, se utilizará una metodología específica para estimar los costes de manera que resulten comparables a nivel internacional.

Costa Rica tiene una base de datos (la SIGECI) donde se incluye la mayoría de sus actividades de cooperación técnica ofrecida (o cooperación financiera noreembolsable), que son actividades de Cooperación Sur-Sur (estricta y bi-direccional),

40 Véase http://www.oecd.org/dac/stats/daclist.htm. 
cooperación bilateral y Cooperación Triangular. Costa Rica ha diseñado una metodología para cuantificar su cooperación técnica (véase abajo).

\section{Expertos contratados en el mercado internacional}

En el caso de que se contraten expertos en el mercado internacional, el precio del contrato será registrado en el TOSSD, independientemente del país de residencia del experto.

En el caso de expertos contratados localmente ${ }^{41}$, la cooperación técnica se medirá a través de la aplicación de una metodología específica para estimar los costes de manera que resulten comparables a nivel internacional.

Los proveedores al desarrollo (cooperantes) entrevistados hacen uso de expertos nacionales/locales e internacionales. Los cooperantes pagan diferentes salarios para estos expertos, siendo los nacionales o locales a veces igual o más caros que los internacionales. Esto es debido al gran nivel de experiencia de los expertos costarricenses. Con el tiempo, los cooperantes suelen contratar cada vez más a expertos nacionales o locales.

Por su parte Costa Rica ha desarrollado una metodología para contabilizar la cooperación técnica en especie (véase Anexo B). Dicha metodología ha sido elaborada por MIDEPLAN y deberá ser utilizada también por las diferentes instituciones gubernamentales que implementan proyectos de cooperación técnica (enlaces institucionales). Dicha información se recogerá por el sistema de SIGECI a partir de 2019.

La metodología mide tanto la cooperación técnica ofrecida por Costa Rica (Cooperación Sur-Sur y Triangular) como la aportación técnica que se realiza para implementar proyectos de cooperación bilateral en Costa Rica (ej. si funcionarios se tuvieron que desplazar para una conferencia a un tercer país). La cooperación técnica se mide en términos financieros, e incluye los siguientes apartados cuantitativos:

- Costes directos: cuando Costa Rica es el país oferente de cooperación técnica, la dirección administrativa y financiera desglosa los costes directos. Existe una tabla de alojamiento y dietas en función del país receptor aportada por la contraloría de la república. ${ }^{42}$ Estos costes incluyen también costes por desplazamientos internos.

- Costes indirectos: son los gastos administrativos de organización del viaje, tales como el acuerdo de viaje, la emisión del pasaporte de servicio, el uso de material del Ministerio, el uso del espacio físico, etc. Es un porcentaje prefijado que se estima en el $5 \%$ de los costes totales para proyectos de cooperación Sur-Sur y triangular (que suelen ser de menor duración) y del $7 \%$ para proyectos de cooperación bilateral tradicional.

\footnotetext{
${ }^{41}$ Los expertos contratados en los países receptores del TOSSD recibirán una remuneración equiparable a los niveles salariales nacionales. Un indicio de contratación local podría ser la remuneración en moneda nacional o el uso de procedimientos del país receptor.

${ }^{42}$ La Contraloría General de la República (CGR) es el máximo órgano de control fiscal del Estado. Como tal, tiene la misión de procurar el buen uso de los recursos y bienes públicos y contribuir a la modernización del Estado, mediante acciones de mejoramiento continuo en las distintas entidades públicas.
} 
- Coste diario del funcionario experto: para lo cual se toma como base el salario medio de un profesional nivel tres de la administración costarricense. ${ }^{43}$

- Coste diario del coordinador institucional del proyecto: sólo hay coordinadores para proyectos de duración de un mes como mínimo y se estima el porcentaje de dedicación al proyecto para calcular este coste en relación al salario del coordinador.

- Días de preparación: esto se determina por el experto, y está entre 3 y 5 días. El salario diario de la preparación es menor que el de ejecución en el terreno (aproximadamente un 33\% del salario diario) porque se asume que no se dedica a tiempo completo a la preparación.

Aunque no se incluyen indicadores cualitativos, Costa Rica estima el valor añadido que aporta el conocimiento acumulado por los expertos que participan en la cooperación técnica. El valor agregado (trayectoria y experiencia acumulada) es una cantidad fija por actividad (no por día o proyecto) que varía en función de la experiencia del experto. Para expertos junior (de entre 5 y 10 años de experiencia) se estima en 150 dólares estadounidenses. Para expertos con más de 10 años de experiencia, se estima en 250 dólares estadounidenses. Este 'valor agregado' es relativamente novedoso ya que no se incluye en las metodologías de medición técnica de otros países estudiados en el marco de TOSSD (como Chile o México).

El país dispone de cierta información sobre sus proyectos, sin embargo, no se dispone hasta la fecha de información sistemática sobre los costes directos e indirectos de estos expertos que aplique esta nueva metodología. Debería empezar a recogerse datos a finales de 2018. Se ha solicitado dicha información desglosada para poder cuantificar la cooperación técnica de Costa Rica de acuerdo con la metodología que se apruebe por el grupo de trabajo TOSSD y para que ésta pueda incluirse en TOSSD a partir de 2019.

\subsubsection{Medición de recursos movilizados por el sector privado}

El reporte de recursos movilizados desde el sector privado está sometida a normas específicas respecto a la causalidad y los métodos de asignaciones prorrateadas a fin de evitar la inflación artificial del volumen de flujos del TOSSD y la doble contabilización de estos recursos en el plano internacional, en aquellas circunstancias en que exista más de un proveedor oficial implicado en un proyecto que moviliza financiación privada.

Costa Rica no tiene conocimiento de actividades en las que se hayan movilizado recursos privados por el sector privado. Sin embargo, algunos actores entrevistados confirmaron que esta información se envía en algunos casos a las autoridades costarricenses. Por ejemplo, la UE confirmó que en 2017 se movilizaron 3.67 millones de euros de un préstamo de 121 millones de euros.

\footnotetext{
${ }^{43}$ En la administración costarricense existen tres categorías profesionales: técnico, profesional y jefe. Dentro de la categoría profesional el nivel 3 es el mayor nivel.
} 
Tabla 3. Estimaciones de los recursos movilizados desde el sector privado por intervenciones oficiales externas en Costa Rica por proveedor y mecanismo de apalancamiento

Millones de dólares estadounidenses, 2012-2015, precios corrientes

\begin{tabular}{|c|c|c|c|c|c|c|}
\hline & $\begin{array}{l}\text { Préstamos } \\
\text { sindicados }\end{array}$ & Garantías & $\begin{array}{c}\text { Participaciones y } \\
\text { acciones en vehículos } \\
\text { de inversión colectiva }\end{array}$ & $\begin{array}{l}\text { Inversión } \\
\text { directa en } \\
\text { compañías }\end{array}$ & $\begin{array}{l}\text { Líneas } \\
\text { de } \\
\text { crédito }\end{array}$ & TOTAL \\
\hline $\begin{array}{ll}\text { France } & - \\
\text { Proparco }\end{array}$ & & & & & 4,7 & $\overline{4,7}$ \\
\hline IADB Group & 603,9 & & & & & 603,9 \\
\hline $\begin{array}{l}\text { Netherlands - } \\
\text { FMO }\end{array}$ & 15,2 & & & & & 15,2 \\
\hline $\begin{array}{l}\text { Norway } \\
\text { Norfund }\end{array}$ & & & 2,4 & & & 2,4 \\
\hline $\begin{array}{l}\text { United States } \\
\text {-OPIC }\end{array}$ & & 76,6 & & 5,8 & & 82,3 \\
\hline TOTAL & 619,0 & 76,6 & 2,4 & 5,8 & 4,7 & 708,5 \\
\hline
\end{tabular}

Fuente: OECD (2018b), OECD (2019)

Tabla 4. Estimaciones de los recursos movilizados desde el sector privado por intervenciones oficiales externas en Costa Rica por año y mecanismo de apalancamiento

Millones de dólares estadounidenses, 2012-2015, precios corrientes

\begin{tabular}{|c|c|c|c|c|c|c|}
\hline & $\begin{array}{l}\text { Préstamos } \\
\text { sindicados }\end{array}$ & Garantías & $\begin{array}{l}\text { Participaciones y } \\
\text { acciones en vehículos de } \\
\text { inversión colectiva }\end{array}$ & $\begin{array}{l}\text { Inversión } \\
\text { directa en } \\
\text { compañías }\end{array}$ & $\begin{array}{l}\text { Líneas } \\
\text { de } \\
\text { crédito }\end{array}$ & TOTAL \\
\hline 2012 & 22,0 & 19,5 & 2,0 & & & 43,5 \\
\hline 2013 & 559,7 & 39,8 & & & & 599,4 \\
\hline 2014 & 8,5 & 7,3 & 0,4 & & & 16,2 \\
\hline 2015 & 28,9 & 10,0 & & 5,8 & 4,7 & 49,4 \\
\hline TOTAL & 619,0 & 76,6 & 2,4 & 5,8 & 4,7 & 708,5 \\
\hline
\end{tabular}

Fuente: OECD (2018b), OECD (2019)

Tabla 5. Estimaciones de los recursos movilizados desde el sector privado por intervenciones oficiales externas en Costa Rica por sector y mecanismo de apalancamiento

Millones de dólares estadounidenses, 2012-2015, precios corrientes

\begin{tabular}{|c|c|c|c|c|c|c|c|}
\hline & & $\begin{array}{l}\text { Préstamos } \\
\text { sindicados }\end{array}$ & Garantías & $\begin{array}{c}\text { Participaciones y } \\
\text { acciones en } \\
\text { vehículos de } \\
\text { inversión colectiva }\end{array}$ & $\begin{array}{l}\text { Inversión } \\
\text { directa en } \\
\text { compañías }\end{array}$ & $\begin{array}{l}\text { Líneas } \\
\text { de } \\
\text { crédito }\end{array}$ & TOTAL \\
\hline $\begin{array}{l}\text { Transporte } \\
\text { almacenamiento }\end{array}$ & $\mathrm{y}$ & 13,7 & & & & & 13,7 \\
\hline Energía & & 512,2 & & & 5,8 & & 518,0 \\
\hline $\begin{array}{l}\text { Servicios } \\
\text { bancarios } \\
\text { financieros }\end{array}$ & $\mathrm{y}$ & 13,1 & 76,6 & & & 4,7 & 94,4 \\
\hline $\begin{array}{l}\text { Industria, } \\
\text { Minería, } \\
\text { Construcción }\end{array}$ & & 80,0 & & 2,4 & & & 82,4 \\
\hline TOTAL & & 619,0 & 76,6 & 2,4 & 5,8 & 4,7 & 708,5 \\
\hline
\end{tabular}

Fuente: OECD (2018b), OECD (2019) 


\section{Segundo pilar del TOSSD: los bienes públicos globales}

En vista de la naturaleza holística de TOSSD, las primeras discusiones sobre el marco destacaron la posibilidad de tomar también en cuenta las contribuciones hechas no a un país concreto sino los recursos invertidos a nivel regional o global para contribuir al desarrollo sostenible. En la práctica, la medida tendría en cuenta las contribuciones a i) las actividades globales y regionales que no darían lugar a flujos transfronterizos y ii) a las instituciones pertinentes en las áreas como la que se indica en el gráfico a continuación.

\section{Gráfico 5. Ejemplos de habilitadores del desarrollo y retos globales}

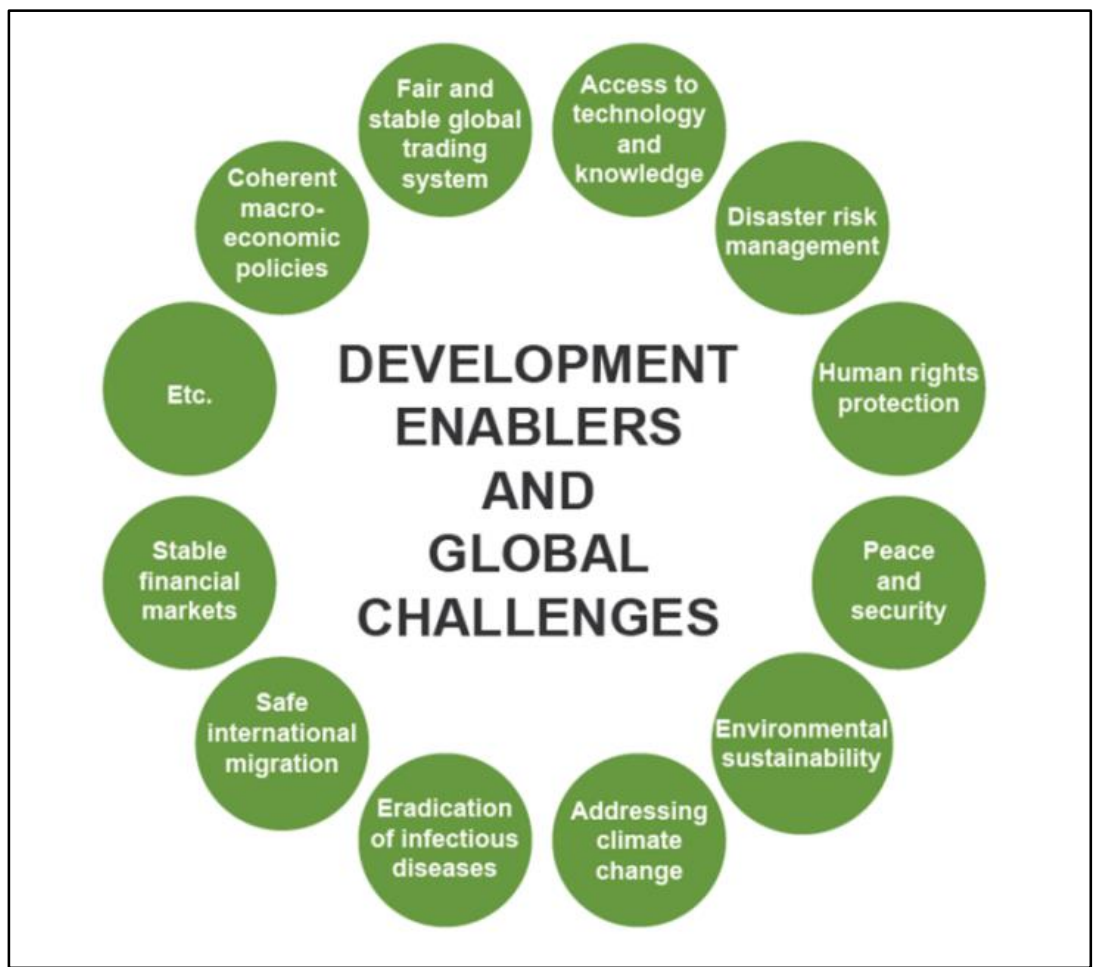

No hubo comentarios específicos sobre el segundo pilar de TOSSD. Algunos entrevistados sugirieron que este pilar debería tener una visión holística. 


\section{Formato de reporte, ciclo de reporte e instrucciones detalladas}

Las principales instituciones de recogida de datos sobre cooperación al desarrollo externa y el sistema informático de recogida de datos de Costa Rica, como país receptor, son las siguientes:

- La Dirección de cooperación de MIDEPLAN: recopila en SIGECI (Sistema de Gestión de Proyectos de Cooperación Internacional) la información sobre cooperación financiera no reembolsable y cooperación técnica. Se pretende también incluir en la información sobre contrapartidas la cuantificación de la cooperación técnica, incluida la transferencia de conocimiento (ver sección 2.3.1 Parte III medición de la cooperación técnica). Sin embargo, existen lagunas por ciertos ministerios y organismos autónomos que no reportan, incluidas las universidades. También para el 2019 se tiene previsto incluir un marcador sobre aporte externos de cooperación técnica y financiera no reembolsable en materia de Cambio Climático (adaptación y mitigación) en el marco de las finanzas climáticas y hacer lo mismo para el tema de flujos migratorios y refugiados.

- Dirección de inversiones de MIDEPLAN: recopila con la plataforma DELPHOS datos de inversión pública (para más información véase sección 2.1.2. Parte III. colecta de datos de préstamos). Esta información está públicamente disponible. Esta plataforma tiene más de 80 variables.

- Ministerio de Hacienda: recopila con SIGADE (Sistema Gestión y Administración de Deuda Externa) datos de inversión pública.

Debe aclararse que los sistemas de DELPHOS y SIGADE son diferentes y recogen diferente tipo de información. No existe todavía un ejercicio de armonización o de coordinación entre plataformas.

Como proveedor, en SIGECI se recogen datos de cooperación técnica en especie.

En cuanto al conocimiento y uso de la plataforma IATI la mayor parte de la administración afirmó conocerla. Ninguno de los actores entrevistados para este estudio manifestó utilizar los datos de IATI.

En cuanto al formato de reporte y qué parte de este informe se podría recoger, en general Costa Rica podría, como proveedor, rellenar todos los campos de dicho formato para todos los tipos de flujos que recoge (no se recoge información sobre fondos privados movilizados). El mapeo con los ODS se hace a nivel meta, aunque alguna parte de la administración no tiene todas las actividades clasificadas para todos los ODS. En principio habría interés y posibilidad en reportarlo a nivel de meta.

La clasificación sectorial es diferente en función de qué parte de la administración reporte, pero Costa Rica podría utilizar la clasificación sectorial propuesta para TOSSD. La información de cofinanciación de inversiones se recoge en cuanto a la parte pública.

En cuanto a sugerencias de campos adicionales, los entrevistados proponen añadir las contrapartidas nacionales para proyectos de desarrollo, lo cual podría incluir tanto las 
contrapartidas financieras como la monetización de la contrapartida técnica, para lo cual se ha diseñado una metodología (véase sección 2.3.1 Parte III Medición de la cooperación técnica). Existe también un campo al respecto en la base de datos de SIGECI donde se contabiliza el aporte externo (cooperantes) y el aporte local nacional (contrapartidas de las instituciones). Esto daría visibilidad al esfuerzo de los receptores de TOSSD. Asimismo, la unidad de inversión de MIDEPLAN incluye la localización geográfica de los proyectos ${ }^{44}$, lo cual permite la participación ciudadana y aumenta la rendición de cuentas, también sugieren añadirla. Igualmente, un Ministerio propuso que las agencias implementadoras reporten los gastos administrativos y pago de expertos, pues normalmente los cooperantes no desglosan los mismos a Costa Rica y desearían disponer de dicha información. Se sugiere que haya un campo 18.b que se denomine "De los cuales gastos administrativos", como una sub-categoría del coste total.

En cuanto a las modalidades de cooperación, se sugiere que se incluyan dos modalidades diferentes para la cooperación Sur-Sur: bidireccional y tradicional. En la primera habría intercambio más o menos equitativo de conocimientos mientras que en la cooperación tradicional existe un país que transfiere conocimientos a otro.

Finalmente, se sugiere clarificación de la definición de vía de canalización o la creación de dos sub-categorías. La actual definición tiene difícil encaje con la modalidad de cooperación Sur-Sur puesto que no siempre la entidad responsable de la implementación es sobre la que recae la responsabilidad de los fondos, por ejemplo, cuando existe una agencia que maneja los fondos, pero implementa otra. Se sugiere aclarar la definición o incluir dos campos: uno para la ejecución técnica y otro para la administración de los recursos financieros.

\footnotetext{
${ }^{44}$ Véase http://mapainversionescr.mideplan.go.cr/
} 


\section{Gráfico 6. Formulario de reporte por nivel de actividad para los flujos transfronterizos del TOSSD hacia los países en desarrollo}

\begin{tabular}{|c|c|}
\hline Elementos de reporte & Notas aclaratorias \\
\hline \multicolumn{2}{|r|}{ A. Datos de identificación } \\
\hline 1. Año de reporte & $\begin{array}{l}\text { Año natural al que hacen referencia los datos (p. ej., reporte en } 2019 \text { sobre los flujos de recursos de } \\
\text { 2018). }\end{array}$ \\
\hline 2. País proveedor/institución & Cada país o institución multilateral que reporta tiene su propio código. \\
\hline 3. Agencia proveedora & $\begin{array}{l}\text { La agencia proveedora es la entidad gubernamental (agencia o departamento central, estatal o del } \\
\text { gobierno local) que financia la actividad de su propio presupuesto. En el caso de organizaciones } \\
\text { multilaterales, se refiere al departamento o fondo que financia la actividad dentro de la institución. La } \\
\text { agencia proveedora tiene responsabilidad presupuestaria y controla la actividad por cuenta propia. }\end{array}$ \\
\hline $\begin{array}{l}\text { 4. Número del proyecto del } \\
\text { proveedor }\end{array}$ & $\begin{array}{l}\text { El campo del número del proyecto facilita el seguimiento de las actividades en las bases de datos } \\
\text { internas de las instituciones proveedoras, lo que puede ser necesario, por ejemplo, para responder a las } \\
\text { peticiones de verificación de datos relativas a determinadas actividades reportadas. }\end{array}$ \\
\hline $\begin{array}{l}\text { 5. Número de identificación del } \\
\text { TOSSD }\end{array}$ & $\begin{array}{l}\text { Además del número del proyecto del proveedor, el número de identificación del TOSSD es necesario } \\
\text { para garantizar la exclusividad de cada transacción en la base de datos y para conectar los compromisos } \\
\text { originales con los desembolsos subsiguientes durante varios años o entre diferentes componentes del } \\
\text { mismo proyecto. Es necesario que el formato sea común para todos los proveedores. Configure el } \\
\text { número de identificación con trece dígitos, siendo las tres primeras cifras coincidentes con el código del } \\
\text { país proveedor/institución: p. ej., para la institución número 901, el número de identificación del TOSSD } \\
\text { sería 901YYYYxxxxxx. }\end{array}$ \\
\hline \multicolumn{2}{|r|}{ B. Datos básicos } \\
\hline 6. Título del proyecto & Título oficial del proyecto. \\
\hline 7. Descripción & $\begin{array}{c}\text { En inglés, francés o español (la intención futura es poder recoger esta información en todos los idiomas } \\
\text { de las Naciones Unidas). }\end{array}$ \\
\hline 8. Receptor del TOSSD & Cada país receptor tiene su propio código. \\
\hline 9. Vía de canalización & $\begin{array}{l}\text { La vía de canalización es el principal socio responsable de la implementación. Es la entidad sobre la que } \\
\text { recae la responsabilidad de implementación de los fondos y que suele estar vinculada a la agencia } \\
\text { proveedora mediante un contrato o cualquier otro acuerdo vinculante, y que es directamente responsable } \\
\text { ante ella. }\end{array}$ \\
\hline 10. Tipo de flujo de recursos & $\begin{array}{l}\text { Se distingue entre actividades oficiales y actividades con apoyo oficial, esto es, recursos movilizados } \\
\text { desde el sector privado. En el caso de las transacciones financieras, se realiza una distinción entre las } \\
\text { transacciones a corto y a largo plazo. }\end{array}$ \\
\hline 11. Instrumento financiero & $\begin{array}{l}\text { Se distingue entre donaciones, instrumentos de deuda, financiación mezzanine, participaciones y } \\
\text { acciones en vehículos de inversión colectiva, y garantías y otros pasivos contingentes no financiados. } \\
\text { [Falta elaborar la financiación islámica] }\end{array}$ \\
\hline 12. Modalidad & Se diferenciará entre las distintas modalidades de cooperación para el desarrollo (falta elaborar). \\
\hline $\begin{array}{l}\text { 13. ODS de interés (selección } \\
\text { múltiple) }\end{array}$ & $\begin{array}{l}\text { Las "metas" tal y como se describen en la lista de metas de los ODS del CENU (p. ej., } 2.1 ; 3.3 \text { ). Se } \\
\text { admite una selección múltiple de respuestas. En caso de no hallarse una conexión directa con una meta } \\
\text { de los ODS, notifique el objetivo [y facilite una justificación para la inclusión de la actividad en el TOSSD]. }\end{array}$ \\
\hline $\begin{array}{l}\text { 14. Código del sector/finalidad } \\
\text { (selección múltiple) }\end{array}$ & Clasificación y códigos pendientes de concretar. \\
\hline 15. Acuerdos de cofinanciación & $\begin{array}{c}\text { Información descriptiva, cuando proceda, sobre los acuerdos de cofinanciación más amplios, tales como } \\
\text { el nombre de los cofinanciadores públicos y privados, el tipo de acuerdos de cofinanciación (préstamo } \\
\text { sindicado, fondos de inversión, financiación de proyecto, etc.) y la financiación de contrapartida del } \\
\text { gobierno receptor. }\end{array}$ \\
\hline \multicolumn{2}{|c|}{ C. Datos sobre volumen (importes expresados en miles, susceptibles de ser ajustados para algunas monedas en caso necesario) } \\
\hline 16. Moneda & Los importes se reportan en la moneda en que se ha realizado la transacción. \\
\hline 17. Importes comprometidos & Nuevos importes comprometidos durante el año de reporte, esto es, el valor nominal de la actividad. \\
\hline 18. Importes desembolsados & Importes desembolsados durante el año de reporte. \\
\hline 19. Importes recibidos & $\begin{array}{l}\text { Incluye la recuperación de donaciones, amortización de préstamos, y pérdidas o ganancias derivadas de } \\
\text { la venta de participaciones (un importe positivo significa que el país proveedor ha obtenido ganancias de } \\
\text { capital; un importe negativo significa que ha experimentado pérdidas de capital). La amortización se } \\
\text { refiere a los pagos del principal recibidos del país prestatario durante el año de reporte, incluido cualquier } \\
\text { pago de atrasos del principal. }\end{array}$ \\
\hline 20. Mecanismos de apalancamiento & $\begin{array}{l}\text { Se refiere al instrumento de apalancamiento utilizado, por ejemplo, garantía, préstamo sindicado, } \\
\text { acciones en vehículos de inversión colectiva. }\end{array}$ \\
\hline 21. Importe movilizado & Informa sobre la cuantía de recursos movilizados [siguiendo las metodologías incluidas en el Anexo]. \\
\hline 22. Origen de los fondos movilizados & Distingue entre fondos movilizados en el país del proveedor, del receptor o terceros países. \\
\hline \multicolumn{2}{|l|}{ Solo para préstamos } \\
\hline 23. Vencimiento & Período de repago en meses. \\
\hline
\end{tabular}




\section{Parte IV. Perspectiva de Costa Rica como proveedor de cooperación al desarrollo}

Esta parte describe el panorama general de Costa Rica como proveedor de cooperación al desarrollo. El país tiene un rol dual como proveedor y receptor de cooperación al desarrollo. Proporciona cooperación técnica en especie, incluida la cooperación triangular, e incurre en gastos para la manutención temporal de migrantes y refugiados dentro de sus fronteras. Asimismo, proporciona contribuciones financieras a organismos multilaterales, principalmente contribuciones obligatorias, aunque el Costa Rica no considera que estas contribuciones sean cooperación al desarrollo. 


\section{Perspectiva sobre flujos oficiales}

El estudio piloto estudió también la perspectiva de Costa Rica como proveedor de cooperación para el desarrollo. Cabe señalar que para Costa Rica es importante que se visibilice su rol de cooperante con un rol dual. Presentarlo como un proveedor neto de cooperación al desarrollo sería incorrecto.

El país se considera a sí mismo como un proveedor de cooperación técnica únicamente pues las únicas contribuciones financieras que realiza son contribuciones a organismos multilaterales, en su mayor parte contribuciones obligatorias por membresía. Una parte importante de la administración considera que hasta que estas contribuciones tengan un impacto visible en países en desarrollo y no se destinen únicamente a sufragar los gastos de funcionamiento de los organismos no puede considerarse como cooperación al desarrollo. Algunos de los actores entrevistados dentro de la administración no obstante estarían a favor de incluirlos. El país estaría dispuesto a reportar estas contribuciones como TOSSD con el fin de que los datos sean comparables internacionalmente, añadiendo eso sí metadatos para explicar esta particularidad en la base de datos.

Costa Rica no tiene ejército, aunque sí realiza contribuciones a operaciones de mantenimiento de la paz, tales como las de Naciones Unidas, y podría reportar las mismas.

Asimismo, es importante resaltar que debido a la crisis fiscal que atraviesa Costa Rica, el país está teniendo dificultades para mantener la cooperación Sur-Sur. La administración ha tenido que renunciar a implementar ciertos proyectos de cooperación Sur-Sur (que se financian bajo la modalidad de costos compartidos) por falta de fondos, y se han paralizado numerosos iniciativas y viajes de trabajo por la misma razón. Si no se solventa, Costa Rica podría volver a ser únicamente un receptor de cooperación. Este es uno de los motivos que ha impulsado a Costa Rica a establecer una metodología para contabilizar las contrapartidas técnicas (ver anexo B) con el fin de hacer más visible el hecho de que a que a pesar del contexto complicado existe un esfuerzo económico significativo de Costa Rica en cooperación al desarrollo. También se ha planteado la creación de un fondo de desarrollo sostenible para poder apalancar recursos adicionales con los que poder financiar su cooperación Sur-Sur.

La modalidad de cooperación triangular en que Costa Rica aporta cooperación técnica y otro proveedor el aporte financiero para poder implementar un proyecto en un tercer país se configura como una modalidad que pueda permitir a Costa Rica seguir proporcionando cooperación técnica a países de similar nivel de desarrollo. Con esa modalidad, el país también puede abrirse a establecer alianzas más allá de la región, por ejemplo, con el continente africano.

Además de cooperación técnica, en la que tendrían capacidad de reportar en TOSSD como proveedores de cooperación, existen iniciativas de investigación que realizan las universidades costarricenses con fondos públicos y que podrían considerarse como habilitadores del desarrollo. Sin embargo, la Ley en Costa Rica da plena autonomía a las universidades que no reportan a MIDEPLAN ni a ningún otro órgano sus proyectos de cooperación, por lo que no podría reportarse salvo que se cambie el marco legal. 
Asimismo, Costa Rica asigna fondos dentro de su país para la atención integrada de refugiados y migrantes, siguiendo el enfoque de derechos humanos. Costa Rica ve la migración como una oportunidad que aporta beneficios al país y atiende a la población refugiada por solidaridad internacional. En principio serían capaces de reportar estos gastos a partir de ahora y estarían dispuestos a ello, pero no distinguen los refugiados de los migrantes que no tienen tal condición. Si finalmente en la medida TOSSD sólo se incluyen gastos de refugiados y no de migrantes en países proveedores, la dirección del departamento de migración de MIDEPLAN tendría que estudiar si puede separar dicho gasto. Desde la administración se comunica que, dada la restricción fiscal, la financiación de esta política es al mismo tiempo un desafío, por lo que necesitarían recibir ayuda internacional para poder realizar una mayor atención. Sin embargo, legalmente existe un impedimento porque la dirección de migración no puede aceptar fondos del exterior salvo que lo gestione la propia entidad proveedora. Sí aceptan donaciones en especie, por ejemplo, el aporte de personal por parte del ACNUR que Costa Rica tiene la posibilidad de seleccionar.

Finalmente, Costa Rica no proporciona becas a otros países, aunque les gustaría hacerlo en el futuro si la financiación se lo permite, pues Costa Rica es una firme defensora de la educación como ascensor social.

El país ha proporcionado datos para realizar estimaciones sobre los flujos de Costa Rica como proveedor. Para el año 2018, proporcionó datos sobre costes administrativos, y contribuciones a organismos de las Naciones Unidas, incluidas contribuciones a operaciones de mantenimiento de la paz. No se proporcionan los datos sobre refugiados y ayuda humanitaria. Tampoco se proporcionan los datos de cooperación Sur-Sur y triangular puesto que se proporciona cooperación técnica y la metodología de medición de la cooperación técnica es reciente, por lo que el país todavía no recoge información financiera sobre la misma.

Las estimaciones de los flujos de Costa Rica como proveedor en 2018 ascienden a 9,5 millones de dólares estadounidenses, de los cuales 9,3 millones son contribuciones a organismos y 159 mil dólares en concepto de gastos administrativos (ver anexo D). 


\section{Perspectiva sobre otros flujos transfronterizos que pueden ser parte de "indicadores satélite": inversiones privadas, filantropía privada y remesas}

Si bien este no es el enfoque principal del piloto, la misión en el país evaluó también el potencial de identificar indicadores adicionales al marco de TOSSD desde la perspectiva costarricense. Estos recursos privados podrían considerarse "indicadores satélite," que no son parte del marco de medida TOSSD pero pueden proporcionar información interesante sobre otro tipo de flujos para el desarrollo sostenible.

El Banco Central de Costa Rica recoge datos sobre IDE privada, donaciones filantrópicas y remesas. Dicha información es confidencial por lo que únicamente la publican de manera agregada, con cierta desagregación por país de origen y destino en cuanto a las remesas. Las remesas y donaciones se registran en la cuenta de ingreso secundario de la balanza por cuenta corriente del país. Los datos sobre remesas se estiman a partir de encuestas.

El principal desafío al que se enfrenta el país para proporcionar datos sobre inversión privada es que hasta la fecha no existe una disposición legal que obligue a las empresas a proporcionar datos sobre inversiones privadas para tener estadísticas oficiales. Por ello muy probablemente los datos estadísticos que se recogen no son completos. El país está discutiendo modificar la ley para garantizar que el sistema estadístico nacional pueda requerir información a las empresas y que sea vinculante.

Un ejemplo de acuerdo de financiación que incluye recursos públicos y privados es el proyecto del tren de pasajeros de la zona de San José, detallado en el Gráfico 7.Gráfico 7. Ejemplo de un acuerdo de financiación complejo: el proyecto del tren de pasajeros de la zona suburbana de San José

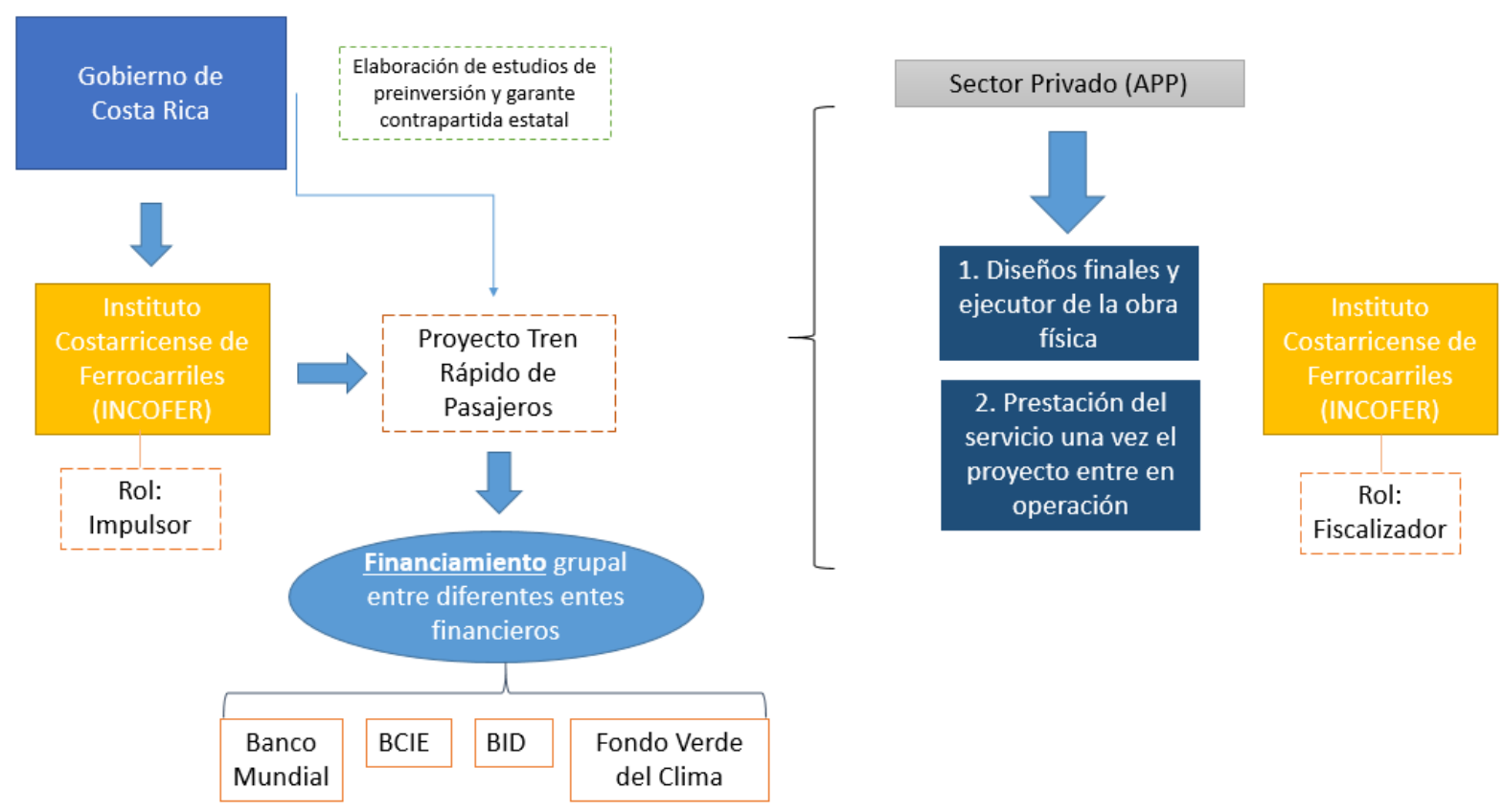

Fuente: MIDEPLAN, 2018 
Parte V. Evaluación de la capacidad del gobierno de costa rica para acceder, recopilar, analizar y utilizar flujos oficiales y privados externos

Esta sección elabora los principales hallazgos del análisis de capacidad en relación a cada uno de los hitos principales en el ciclo de gestión de datos para recursos externos de financiación para el desarrollo. 


\section{Descripción general de la arquitectura institucional legal para datos de financiamiento del desarrollo}

Costa Rica tiene una gestión "dual" en el tratamiento de la cooperación, tal y como lo señala el artículo 11 de la Ley de Planificación Nacional 5525 de 1974 y sus reformas, que indica que corresponde al MIDEPLAN: “(...) formular, negociar, coordinar, aprobar y evaluar los programas de asistencia técnica, teniendo en cuenta los objetivos del Plan Nacional del Desarrollo (...)”. Dice además que “(...) las solicitudes de asistencia técnica serán transmitidas por MIDEPLAN al Ministerio de Relaciones Exteriores, el cual se encargará de establecer su congruencia con la política exterior del país y los presentará oportunamente a los gobiernos y organismos internacionales correspondientes".

El mecanismo de coordinación institucional es el que se muestra en el Gráfico 8.

Gráfico 8. Mecanismo de coordinación interinstitucional

\section{Mecanismo de coordinación interinstitucional: cooperación norte-sur (Costa Rica como receptor)}

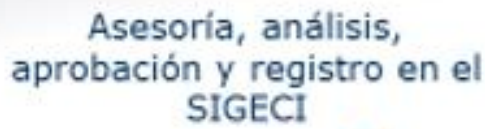

5
Presentación oficialy congruencia con la Pol. Ext de CR.

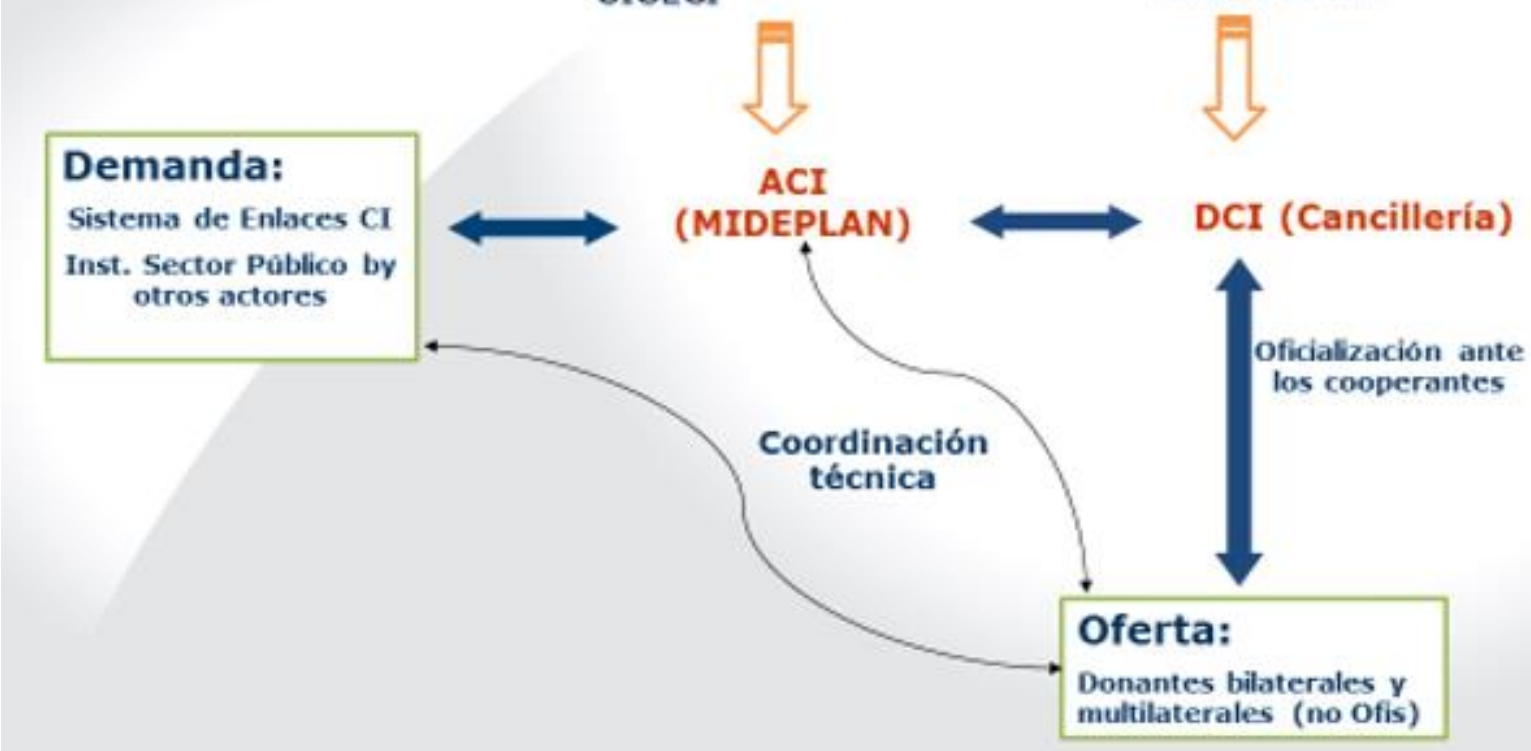

Nota: las flechas con doble punta indican comunicación oficial bidireccional Fuente: MIDEPLAN

Los ministerios e instituciones del sector público (Subsistema Nacional de cooperación) utilizan un sistema de enlaces de cooperación internacional para contactar a MIDEPLAN cuando quieren implementar un proyecto de cooperación internacional. 
MIDEPLAN está organizado en dos unidades dentro del departamento de cooperación, la de cooperación bilateral y la cooperación multilateral. La unidad de cooperación bilateral está estructurada a su vez, por continentes (Europa, Asia/Oceanía y América); la unidad de cooperación multilateral según tipo de organismo (la Unión Europea, el sistema interamericano, el sistema de Naciones Unidas y los bancos de desarrollo). Finalmente, la cooperación sur-sur y la triangular se trabajan de forma transversal.

Gráfico 9. Organigrama de MIDEPLAN

\section{MINISTERIO DE PLANIFICACION NACIONAL Y POLITICA ECONOMICA AREA DE COOPERACION INTERNACIONAL Estructura Operativa (Ley N.5525, Ley N. 7518 y Decreto 36056-PLAN-RE)}

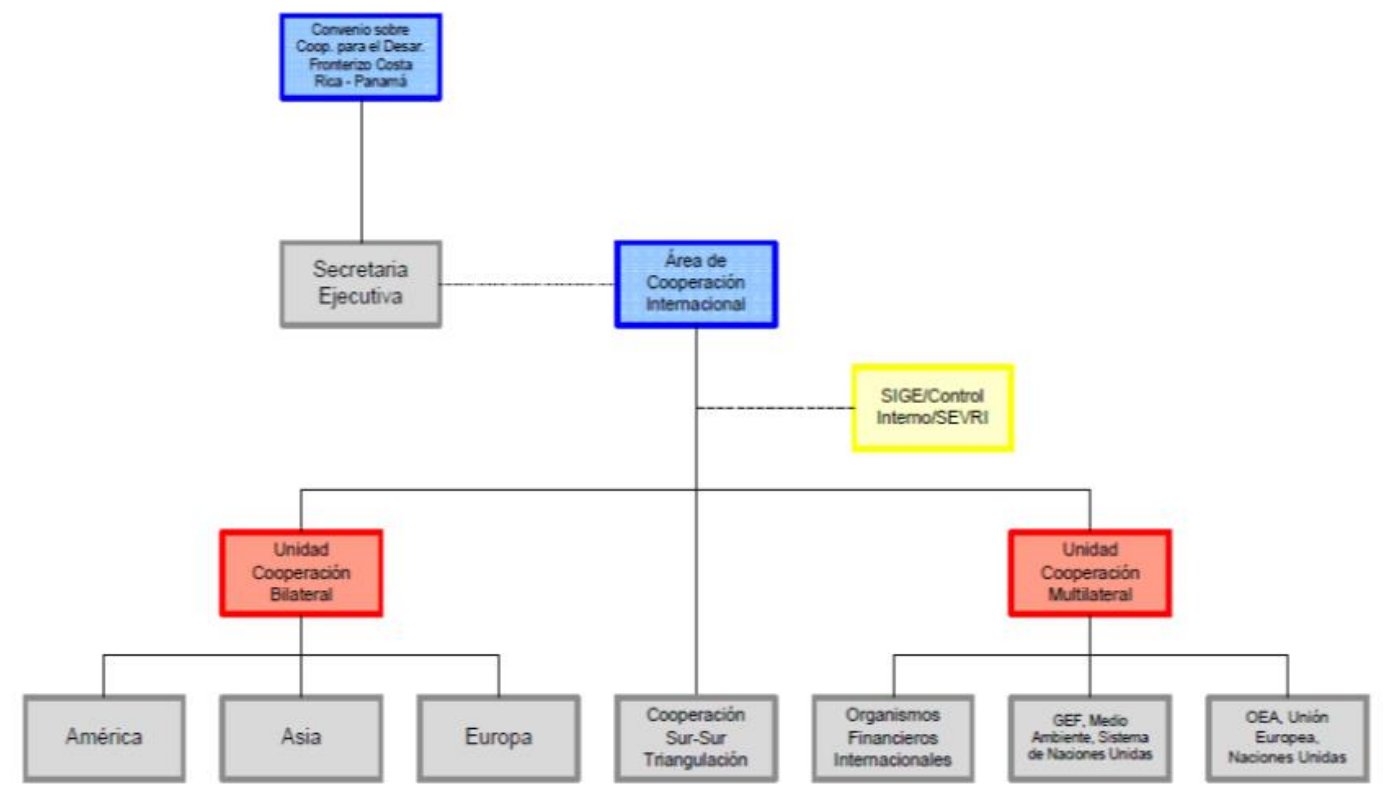

Fuente: MIDEPLAN

Un proyecto dado se analiza para ver la coherencia interna con el PND. Si se considera que tiene todos los requisitos para aprobación se introduce en la plataforma SIGECI. Posteriormente MIDEPLAN remite el proyecto a la Dirección de Cooperación Internacional de la Cancillería, para que ésta a su vez, analice la coherencia externa de los proyectos con la política exterior del país y oficializa con los cooperantes tanto bilaterales como los multilaterales los proyectos de cooperación.

A su vez, tanto los enlaces institucionales como MIDEPLAN coordinan a nivel técnico con los cooperantes bilaterales y multilaterales en cuanto a la formulación de los proyectos. Este sistema implica una gran coordinación entre MIDEPLAN y Cancillería.

En cuanto a la cooperación reembolsable (proyectos de inversión), el área de inversiones de MIDEPLAN tiene la rectoría técnica del sistema nacional de inversión pública de Costa Rica. El área está separada en dos unidades: pre-inversión con un fondo que financia estudios previos para proyectos de inversión importantes y la unidad de 
inversiones pública, que elabora las políticas, directrices y lineamientos de inversión pública.

Por su parte, Hacienda está a cargo de las estadísticas de crédito público, en una base de datos diferente de la de MIDEPLAN. Estas estadísticas pueden complementar a las cifras de la cooperación en general. Se recogen estadísticas tanto de financiación concesional como no concesional. Se realiza por un lado un mero registro estadístico y contable y por otro lado se da seguimiento a los proyectos de inversión pública con financiación de organismos multilaterales: desembolsos, intereses, contrapartida local, etc. Ambos están disponibles en la página web del ministerio. ${ }^{45}$ En la próxima sección se proporciona más detalle en cuanto a la recogida de datos.

Finalmente, debe añadirse que Hacienda realiza y recoge también información sobre aportes de capital a los organismos multilaterales.

45 Ver https://www.hacienda.go.cr/contenido/14626-seguimiento-de-proyectos-financiadoscon-endeudamiento-publico 


\title{
2. Evaluación de la capacidad del gobierno de Costa Rica para gestionar datos sobre financiación para el desarrollo
}

\author{
2.1 Evaluación de la capacidad nacional para recoger \\ información sobre financiación para el desarrollo
}

\subsubsection{Colecta de datos de donaciones y asistencia técnica}

Existe información y un sistema para recoger datos de desembolsos (no compromisos) de cooperación financiera no reembolsable: donaciones $\mathbf{y}$ asistencia técnica. Sin embargo, el sistema no es completo debido principalmente a que la legislación no obliga a todos los actores a reportar al sistema.

El país recoge datos únicamente de desembolsos. Las cifras de promesas de financiación son muy volátiles para el país y no se dispone en la mayoría de los casos de dicha información. En este sentido como receptora, la administración costarricense es más reactiva que proactiva y tiene poca capacidad de planificar. Únicamente cuando se produce un desastre natural se realiza una petición de fondos como tal, pero se trata de promesas de muy corto plazo.

SIGECI no recoge la totalidad de las donaciones recibidas por parte de la administración. Esto es así porque hay una parte de los actores nacionales que están obligados a ello que no reportan, a pesar de que desde MIDEPLAN se recuerda a cada administración que es su obligación de reportar y canalizar los proyectos por medio de MIDEPLAN. Por ejemplo, en el trascurso de las entrevistas, se puso de manifiesto que los datos de becas recibidas están en Cancillería pero que ésta no reporta a MIDEPLAN. La información está disponible y se envió bajo petición (se recibieron 1.163 becas en 2016, 985 en 2017 y 402 al 1 de octubre de 2018 aunque no se proporcionó información sobre los montos). Asimismo, durante las entrevistas tuvimos conocimiento de una serie de proyectos llevados a cabo por INCOPESCA y cooperación técnica llevada a cabo por AMEXCID que tampoco se recogen en el sistema. Igualmente, no se recogen los datos regionales sino únicamente los nacionales, por lo que queda fuera una parte importante de los proyectos de cooperación. Esto puede deberse a una falta de coordinación o a una falta de comprensión por parte de ciertos organismos de lo que se entiende por cooperación (especialmente la Sur-Sur) por lo que las actividades de cooperación no se identifican como tal.

Además, la legislación no obliga a reportar a una serie de actores que también pueden estar implicados en proyectos de cooperación, como los gobiernos locales, las universidades, las entidades autónomas estatales, las ONGs y las organizaciones de la Iglesia. Esto ocasiona también un sub-reporte en SIGECI.

En cuanto a las donaciones o préstamos por parte del sector privado, ahora mismo no se recogen en SIGECI porque la obligación legal sólo aplica a los enlaces institucionales, que son organismos públicos. La Alianza Empresarial para el Desarrollo (AED) manifestó la voluntad de colaborar para que puedan introducirse datos sobre estos proyectos en SIGECI. Se nos informó que Hacienda tiene una lista de organismos declarados de utilidad pública y que reciben fondos de cooperación, por lo que puede ser una manera de identificar dichos organismos e invitarlos a reportar. Además, recientemente se han elaborado dos decretos para regular las alianzas público privadas 
(APP) y las alianzas público privadas para el desarrollo (APPD). Este proyecto ha estado liderado por el Ministerio de Economía, Industria y Comercio y el despacho de la segunda vicepresidenta. Igualmente, el Ministerio de Relaciones Exteriores y Culto lanzó el año pasado la política nacional de la responsabilidad social de empresas, aunque todavía no existe reglamentación al respecto. Con la creación de más APP y APPDs y con el avance de la reglamentación en cuanto a la responsabilidad social corporativa, se espera que se incrementen los esquemas de financiación público-privados y con ellos la información sobre financiación privada movilizada por intervenciones oficiales.

Costa Rica pretende recoger información de proyectos que no son de cooperación estricto sensu, en los que un organismo internacional gestiona la financiación pública (mecanismo cost-sharing), por ejemplo, UNOPS (United Nations Office for Project Services) para infraestructuras. Estos organismos no aportan ninguna cantidad de recursos y cobran un porcentaje por la gestión de los fondos, por lo que prestan un servicio que es remunerado. Al no encajar en la lógica tradicional de cooperación para el desarrollo se va a incorporar un nuevo módulo en SIGECI para ingresar estos proyectos en la plataforma. En otros casos sí incluyen contrapartida y sí se consideran cooperación, y se está desarrollando conceptualmente la manera de reflejarlo en SIGECI.

Asimismo, va a incorporarse un nuevo módulo a SIGECI para gestionar las finanzas climáticas. Se debe a una iniciativa de finanzas para la diversidad (biofin) que se está desarrollando con la colaboración de la agencia de cooperación alemana GIZ. El objetivo del proyecto es (i) detectar la brecha financiación para la biodiversidad (ii) inversión (iii) estrategia de movilización de recursos para cubrir dicha brecha. GIZ está trabajando junto con MIDEPLAN, Hacienda y el Banco Central para investigar la inversión en cambio climático porque la estructura presupuestaria actual no permite identificarlo. Para ello se utilizan los marcadores de la Convención Marco de las Naciones Unidas sobre el Cambio Climático (CMNUCC). Como se ha mencionado anteriormente, Costa Rica no tiene datos de compromisos por lo que se identifica en base los desembolsos. Los proyectos debe refrendarlos la contraloría general de la República, y únicamente se miden las condiciones financieras y no se hace un análisis de gobernanza o de las implicaciones políticas.

Finalmente, en cuanto a la cooperación no reembolsable proporcionada por Costa Rica y los gastos incurridos para refugiados y migrantes dentro de su territorio, como se comenta en la sección III, actualmente no se encuentra disponible. Costa Rica no mide actualmente su cooperación técnica, pero va a empezar a hacerlo a partir de 2019 y la dirección de migración también estaría dispuesta a recoger dicha información. Tampoco incluye información de las contribuciones a organismos multilaterales, que se recoge por parte del Ministerio de Hacienda, por no considerarlo cooperación al desarrollo. En cuanto a la investigación que realizan las universidades con fondos públicos y que entrarían dentro del pilar de habilitadores del desarrollo con la legislación actual sería complicado que lo pueda cuantificar por la autonomía de las universidades, que no obliga al reporte como hace con otros organismos públicos.

\subsubsection{Colecta de datos de préstamos y otros instrumentos financieros}

La información de préstamos está dispersa y fragmentada a lo largo de la administración. El Centro Nacional de Concesiones (CNC) recoge información respecto a esta figura; existe un departamento de inversiones en MIDEPLAN; existe una unidad de crédito público en Hacienda y una oficina de APPs dentro del Ministerio de Hacienda. 
El departamento de inversiones de MIDEPLAN tiene la rectoría técnica del sistema nacional de inversión pública de Costa Rica y recoge la información de préstamos dentro de una base de datos disponible para el ciudadano. Igualmente, el departamento de crédito público de Hacienda tiene una base de datos en formato Excel, por lo que se producen duplicidades de información y de esfuerzos al existir dos bases de datos que no son compatibles entre sí.

El departamento de inversión de MIDEPLAN está separado en dos unidades: preinversión, con un fondo que financia estudios previos para proyectos de inversión importantes; y la unidad de inversiones públicas, que elabora las políticas, directrices y lineamientos de inversión pública.

La rectoría incluye también la competencia de agrupar los datos tanto de recursos reembolsables como de recursos del presupuesto nacional. Éstos se recogen directamente desde las instituciones y se ingresan en una plataforma denominada DELPHOS. Esta plataforma tiene tres módulos diferentes a los cuales todos los ciudadanos pueden acceder desde la web de MIDEPLAN ${ }^{46}$ :

- Banco de proyectos de inversión pública (BPIP). Los responsables de incorporar los datos son las diferentes instituciones, pero desde MIDEPLAN se verifica la calidad de la información antes de que se publiquen los proyectos. En el módulo se incluyen proyectos con diferentes fuentes de financiamiento: bancos multilaterales, instituciones financieras para el desarrollo (IFD), y banca nacional.

- Mapa de inversiones ${ }^{47}$ : donde se visualiza la ubicación de los proyectos. Además, tiene un módulo adicional para propiciar la participación ciudadana en la inversión pública. Genera una interacción donde los ciudadanos pueden rellenar encuestas, subir fotografías, realizar comentarios sobre el estado de avance de los proyectos, etc.

- Pérdidas ocasionadas por fenómenos naturales en los últimos 30 años: tiene información sobre todos los proyectos declarados emergencia nacional. Proporciona las pérdidas generadas en inversión pública por sector y por región. Aquí se ha transversalizado la gestión de riesgos de desastres.

Para asegurar la homogeneización por parte de las unidades que reportan, se han elaborado guías sobre cómo ingresar la información en el sistema. La base de datos se actualiza con frecuencia diaria con los datos incorporados por las instituciones y a septiembre de 2018 tenía unos 2.400 proyectos de inversión.

Una vez visto el formulario de reporte TOSSD, desde el área de inversión pública nos confirman que existe información de buena calidad y suficiente para todos los campos que se solicitan, aunque la misma no está sistematizada y en un solo lugar. Con el fin de que la información llegue con los estándares de calidad adecuados habría que incrementar la coordinación a nivel nacional, y hacer que la información sea acorde con los requerimientos. MIDEPLAN sería la institución más adecuada para poner a

\footnotetext{
${ }^{46}$ Ver https://www.mideplan.go.cr/?option=com_content\&view=article\&id=388

${ }^{47}$ Ver http://mapainversionescr.mideplan.go.cr/
} 
disposición la información por tener más capacidad en cuanto a minería de datos y habría voluntad de ponerla a disposición.

Asimismo, la unidad de crédito público del Ministerio de Hacienda gestiona estadísticas de deuda pública que pueden complementar las cifras de cooperación en un sistema denominado SIGADE. Tienen información y mucha de ella está disponible públicamente en la web del Ministerio ${ }^{48}$. Se registra financiación tanto concesional como no concesional y existen dos fuentes de registro: por un lado, un mero registro estadístico y contable y por otro seguimiento de los proyectos de inversión pública que se financian por parte de organismos multilaterales: datos sobre desembolsos, intereses, contrapartida local, así como cualquier otra cooperación activada para facilitar ese proyecto de inversión pública. Para este último registro uno existe un sistema de seguimiento desarrollado. En cuanto a información sobre financiación privada, no se recoge como tal y únicamente existe información sobre pasivos contingentes de asociaciones público privadas, pero únicamente la parte pública.

\subsubsection{Colección de datos sobre flujos privados}

MIDEPLAN no recoge datos de financiación privada apalancada por intervenciones públicas, aunque la Unión Europea reporta a MIDEPLAN datos sobre blended finance (utilización estratégica de financiación para el desarrollo para movilizar recursos adicionales- principalmente comerciales). La unidad de inversión de MIDEPLAN podría incorporar dicha información a su sistema de recogida de información.

Como se ha mencionado anteriormente acaban de crearse dos decretos para regular APPs y APPDs pero por el momento no es una figura que se utilice y para la cual se tengan datos en el país. La única información que se recoge es del CNC para las concesiones, y se recoge información sobre estructuración financiera del proyecto por instrumento. La inversión privada en sí no se recoge, pero no está en su ámbito de competencia.

\subsection{Evaluación de la capacidad en la recopilación de información sobre financiación del desarrollo.}

La información sobre cooperación financiera y técnica no reembolsable se recoge por MIDEPLAN, por lo que no es necesario recopilarla ya que está en una única base de datos. En cuanto a los datos sobre cooperación financiera reembolsable (inversión pública), existen dos bases de datos paralelas para información. Se han realizado intentos de homogeneizar o fusionar ambas bases de datos, pero no se ha logrado.

La plataforma DELPHOS de MIDEPLAN está intentando ligarse a otras bases de datos existentes en la administración tales como la del presupuesto nacional y la contraloría general de la república. Sin embargo, existen dos bases paralelas de las unidades de

\footnotetext{
${ }^{48}$ Ver https://www.hacienda.go.cr/contenido/14626-seguimiento-de-proyectos-financiados-conendeudamiento-publico
} 
inversión de MIDEPLAN y del Ministerio de Hacienda y no se conectan ni se comparte la información, lo cual dificulta la recopilación de la información.

\subsection{Evaluación de la capacidad en el uso y diseminación de datos sobre financiación al desarrollo}

Costa Rica pone la información que recoge a disposición de los ciudadanos, tanto en la plataforma SIGECI49 como en DELPHOS50, ambos disponibles en la página web de MIDEPLAN. La herramienta SIGADE51, que recoge información sobre crédito público también está disponible para la ciudadanía.

Como se menciona en la sección 2.1.2., la herramienta DELPHOS tiene un módulo en el que aparecen los proyectos por geolocalización y en el que los ciudadanos pueden participar introduciendo información. Existe también un módulo de pérdida por desastres naturales que es muy utilizado por parte de la academia.

Adicionalmente, los datos son diseminados en informes de cooperación al desarrollo.

En base a las entrevistas realizadas y las fuentes consultadas, podemos afirmar que Costa Rica tiene una buena capacidad para el uso y diseminación de los datos de los que dispone.

${ }^{49}$ Accesible en https://mideplan5-n.mideplan.go.cr/cooperacioninternacional/

${ }^{50}$ Accesible en https://www.mideplan.go.cr/?option=com_content \&view=article\&id=388

51 Accesible en https://www.hacienda.go.cr/contenido/14626-seguimiento-de-proyectosfinanciados-con-endeudamiento-publico 


\section{Conclusiones y próximos pasos}

Los hallazgos de este estudio piloto de TOSSD en Costa Rica, han puesto de manifiesto que TOSSD le puede ser útil a un país como Costa Rica que dispone de herramientas de planificación pero que no tiene información completa y agrupada en un solo sistema sobre recursos externos que se dirigen a implementar la Agenda 2030 en el país.

Asimismo, puede incentivar recursos dirigidos a Costa Rica en apoyo del desarrollo sostenible, que para un país de renta media-alta es necesario puesto que muchos donantes han reducido significativamente su AOD. Además, si un día Costa Rica se graduase como receptor de AOD, podría seguir recibiendo flujos de TOSSD si optase al procedimiento voluntario de adhesión.

La mayoría de los conceptos y clasificaciones adoptados por el Grupo de Trabajo TOSSD fueron confirmados por el estudio piloto, lo que pone de manifiesto que el concepto se está desarrollando en la dirección adecuada. Las personas entrevistadas dieron recomendaciones para adaptar dichos conceptos y clasificaciones a la realidad de los países con rol dual de proveedor y receptor de financiación para el desarrollo y de las especificidades de la cooperación Sur-Sur. Los hallazgos de este reporte fueron discutidos por el Grupo de Trabajo TOSSD en su reunión de noviembre 2018 en Suecia y contribuirán a refinar las Instrucciones de Reporte TOSSD, que se espera estén listas en 2019.

Finalmente, los hallazgos de este piloto serán compartidos en varios eventos y foros internacionales. Gracias al apoyo financiero proporcionado por la Unión Europea, se llevó a cabo otro estudio piloto en mayo de 2018 en Nigeria, y se llevarán a cabo otros pilotos TOSSD durante 2019, con el fin de informar el desarrollo del trabajo del Grupo de Trabajo TOSSD y examinar la metodología TOSSD a la luz de los países receptores. 
Anexos

LA PERSPECTIVA DE COSTA RICA SOBRE EL APOYO OFICIAL TOTAL PARA EL DESARROLLO SOSTENIBLE (TOSSD) () OCDE 2019 


\section{Anexo A: breve presentación del proceso de entrevista}

\section{Metodología utilizada}

- La misión en el país se basó principalmente en entrevistas semiestructuradas basadas en el cuestionario de entrevista.

\section{Flujo general de una entrevista}

- Introducción: presentación de las personas que participan en la entrevista

- Explicación de los objetivos del estudio (basado en los términos de referencia).

- Entrevista: se usaron preguntas relevantes de la lista de preguntas del cuestionario. Se formularon otras preguntas basadas en las respuestas proporcionadas con el fin de alcanzar los objetivos del estudio.

- Conclusión y seguimiento: la entrevista terminó explicando los próximos pasos (un informe de estudio).

\section{Preguntas adicionales no presentes en el cuestionario}

- Se formularon preguntas como se indica en el cuestionario de entrevista, pero los miembros del equipo de la OCDE no dudaron en explorar / aclarar cuando fue necesario ciertos elementos basados en las respuestas proporcionadas por los encuestados para cumplir mejor con los objetivos de la misión.

- Si se planteaba una cuestión delicada durante las entrevistas, los entrevistados podían indicar que desean que determinados asuntos no se incluyan en el informe. 
Anexo B: guía para determinar el valor de las contrapartidas institucionales en los proyectos de cooperación internacional

Este anexo incluye la guía para determinar el valor de las contrapartidas nacionales en los proyectos de cooperación internacional, así como el valor de la cooperación técnica en especie proporcionada por Costa Rica. La metodología ha sido desarrollada por MIDEPLAN.

\section{GLOSARIO DE TÉRMINOS Y CONCEPTOS UTILIZADOS}

(a) Costos Directos: son los costos asociados al intercambio de conocimiento (Boletos aéreos, viáticos, transporte interno -combustible- y materiales).

(b) Costos Indirectos: son los costos referidos a apoyo administrativo.

(c) Coordinador/director Institucional del proyecto: es el responsable del proyecto en la institución costarricense.

(d) Cuantificación de experiencia y trayectoria: es el valor que se le agina a un funcionario por concepto de experiencia y trayectoria en el tema.

(e) Publicaciones indexadas: es una publicación periódica de investigación que denota alta calidad y ha sido listada en alguna base de datos/índice/repertorio de consulta mundial. Para determinar si una revista ingresa en una base de datos/ índice/repertorio se tienen en cuenta ciertos indicadores de calidad que pueden variar entre distintas bases de datos, en términos generales pueden ser agrupados en:

- Calidad del contenido de la investigación.

- Identificación de los miembros de los comités editoriales y científicos.

○ Identificación de los autores (nombre, apellidos, afiliación).

- Contenido de la revista: se valora positivamente que la revista incluya un alto número de artículos originales inéditos, informes técnicos, ponencias/comunicaciones a congresos, artículos de revisión.

- Instrucciones detalladas a los autores.

- Artículos acompañados de un resumen, si puede ser resumen en al menos dos idiomas, incluir también palabras clave.

- Características técnicas o formales.

- Periodicidad de las revistas, regularidad y homogeneidad de la línea editorial en caso de editoriales de libros. Que conste claramente la entidad editora.

- Anonimato en la revisión de los manuscritos. 
- La editorial o el comité de selección debe incluir las razones para la aceptación, revisión o rechazo del manuscrito, así como los dictámenes emitidos por los expertos externos.

- Existencia de un consejo asesor, formado por profesionales e investigadores de reconocida solvencia, sin vinculación institucional con la revista o editorial y orientado a marcar la política editorial y someterla a evaluación y auditoría.

- Uso por parte de la comunidad científica. Para medir el uso que la comunidad le ha dado a un artículo, se suele utilizar un indicador que se relaciona con la cantidad de citas que recibe el artículo por parte de otros usuarios, este se denomina factor de impacto. Se usa comúnmente para determinar la visibilidad de un autor, de una disciplina o de una revista. http://bibliosjd.org/2018/03/13/revista-indexada/\#.Wz1HBtJKiUk

\section{INTRODUCCIÓN}

La cuantificación de las contrapartidas institucionales en los países en vías de desarrollo, receptores de cooperación internacional como es el caso de Costa Rica, es una labor aún pendiente, pero necesaria y cada vez más urgente. Es de primera importancia cuantificar y visibilizar los recursos en especie que aportan las instituciones en cada proyecto, indistintamente de su tipo y modalidad. Algunos países ya han avanzado en este proceso tales como Chile, México, Brasil, por citar algunos. Cada uno tiene una metodología diferente, aunque con similitudes.

Por lo anterior, en esta guía se plantea una metodología mixta (en el sentido de utilizar algunos insumos aportados por los países mencionados) y otros propios con el fin de contar con un primer instrumento que permita a las instituciones públicas contabilizar de forma más rigurosa y real, los aportes institucionales que se establecen en cada proyecto y programa de cooperación internacional para el desarrollo.

Es deseable que los recursos internacionales solicitados permitan potenciar, complementar y apalancar los recursos nacionales. En este sentido, es pertinente que los proyectos estén enfocados a la inversión más que a los gastos de funcionamiento.

Por eso, se ha diseñado esta guía para atender la necesidad de que exista estrecha complementariedad entre los aportes técnicos y financieros del país, sean nacionales, locales o regionales junto con el aporte de la cooperación internacional.

Todos los proyectos financiados con recursos externos no reembolsables deben establecer la contrapartida institucional y para calcular dicha contrapartida esta guía establece las variables a considerar, los rubros que cada una comprende y los cálculos respectivos. Esta guía aplica para proyectos de cooperación sur-sur

triangulación, bilaterales y multilaterales. 
Esta Guía es de aplicación obligatoria para todas las instituciones del sector público costarricense y se fundamenta en la normativa que regula la gestión de la Cooperación Internacional, en particular las secciones siguientes del Decreto Ejecutivo 35056-PLANRE:

\section{CAPÍTULO II}

Rectoría y Órganos de la Cooperación Internacional No Reembolsable

\section{SECCIÓN I}

Funciones de MIDEPLAN y de MRREE

Artículo $3^{\circ}$-Funciones de MIDEPLAN.

Le corresponde a MIDEPLAN la rectoría interna en materia de Cooperación Internacional, teniendo la competencia exclusiva en la gestión y la negociación técnica de esta con las entidades, organismos e instituciones nacionales, de manera que sea coherente con el Plan Nacional de Desarrollo. Sus funciones en materia de Cooperación Internacional son:

(Así reformado el párrafo anterior por el artículo 1 del Decreto Ejecutivo 35777 del 8 de enero de 2010).

c) Coordinar el proceso de gestión de la Cooperación Internacional No Reembolsable concertando los medios y esfuerzos necesarios para la consecución de los recursos, según las prioridades definidas en el Plan Nacional de Desarrollo. Para realizar esta labor contará con la colaboración del MRREE y del Sistema de Enlaces de la Cooperación Internacional.

d) Asesorar a las entidades públicas en la formulación de las propuestas de Cooperación Internacional y en todo el proceso de gestión.

\section{VARIABLES Y FÓRMULA}

\subsection{LAS VARIABLES A TOMAR EN CUENTA}

Las siguientes son las variables que se deben utilizar para contabilizar la contrapartida institucional del país en proyectos de cooperación bilateral, multilateral sur-sur y triangulación.

\section{a. Costos Directos:}

- Boletos aéreos

- Alojamiento

- Alimentación

- Transporte interno (combustible)

- Materiales 


\section{b. Costos Indirectos:}

Apoyo Administrativo institucional en un proyecto que se cuantifica por parte de la institución costarricense. Está integrado por: trámites varios, espacio físico, equipos de cómputo, agua, luz, teléfono, impresión de materiales, internet, uso de vehículos, apoyo secretaría.

\section{c. Costo diario por Profesional Experto:}

Es el promedio diario del salario mensual del funcionario costarricense que ha sido asignado para colaborar en un proyecto de cooperación internacional.

\section{d. Costo Diario del Coordinador/Director Institucional de Proyecto: ${ }^{52}$}

Es el promedio diario del salario mensual del funcionario institucional costarricense que ha sido designado para fungir como coordinador del proyecto; este se aplica cuando corresponde.

\section{e. Días de Preparación:}

Se trata de los días que se estiman necesarios para preparar una actividad específica programada en un proyecto. Se considera entre 3 y 5 días de preparación ${ }^{53}$ para cada actividad a lo largo de la ejecución del proyecto. Se cuantifica únicamente cuando se trata de proyectos en la modalidad de cooperación sur-sur y triangulación. En el caso de los expertos en proyectos de cooperación norte-sur se aplica únicamente si van a dar talleres, charlas o conferencias.

Por su parte, cuando se trata de proyectos tradicionales (bilaterales o multilaterales), únicamente se aplica para los expertos profesionales y no al coordinador/director institucional de proyecto.

\section{f. Trayectoria y experiencia acumulada:}

Es la cuantificación de valor acumulado, trayectoria y experiencia en el tema de un funcionario institucional. Puede haber dos (02) categorías: la de Junior o la de Senior.

En el caso de Junior se requiere:

- Entre 5 y 10 años de trabajar en el tema del proyecto

\footnotetext{
${ }^{52} \mathrm{Se}$ trata del funcionario institucional que tiene la responsabilidad de ejecutar el proyecto por parte de Costa Rica.

${ }^{53}$ Es el experto funcionario quien determina el tiempo que requiere para la preparación de la(s) actividad(es)
} 
- En el caso del Senior se requiere:

- Más de 10 años de trabajar en el tema del proyecto

- Que represente a nivel nacional e internacionalmente a la institución en el tema del proyecto.

- Que haya realizado varias publicaciones en la materia (deseable que sean publicaciones indexadas).

\subsection{NOTAS ACLARATORIAS A LAS VARIABLES}

a. Las variables que siempre se deben tomar en cuenta para calcular la contrapartida son: costos indirectos, horas profesionales expertos, salario mensual coordinador institucional de proyecto (cuando aplica), días de preparación y la trayectoria y experiencia acumulada.

b. Los costos directos se calculan tomando como referencia los datos institucionales, para ello se debe consultar a las unidades administrativo-financieras institucionales. $\underline{\mathrm{Si} \text { son }}$ asumidos por el o los cooperantes, no se contabilizan como contrapartida.

c. El Valor Agregado se aplica una vez para el coordinador por cada año de ejecución del proyecto.

Si el proyecto dura menos de un año, se aplica una vez para el coordinador por cada mes de duración del proyecto y para el experto, por cada actividad realizada.

El valor agregado se calcula en función de (02) categorías: junior y senior. Cada uno tiene un coste diferente (Ver tabla 1).

d. El salario promedio mensual de experto profesional es de $\$ 3.400$ (2.000.000 de colones promedio). Lo que equivale a $\$ 115 /$ día para los expertos al tipo de cambio del momento.

e. El salario mensual de un coordinador institucional de proyecto es de $\mathbf{\$ 5 , 2 5 7} \mathbf{U S D}^{54}$ (3.000.000 colones promedio). La actualización del tipo de cambio se hará cada vez que se formule un proyecto.

f. El apoyo Administrativo (costos indirectos). Se aplica 5\% sobre el total de la contrapartida institucional cuando son proyectos de cooperación sur- sur o triangulación y $7 \%$ cuando son proyectos tradicionales bilaterales o multilaterales.

${ }^{54}$ Tipo de cambio venta oficial de 570,65/1USD al 26/06/2018. 
g. Las actividades que realiza el experto pueden ser talleres, charlas, reuniones técnicas, revisión de documentos, misiones y visitas de campo, asesorías técnicas puntuales, entre otros.

\subsection{PRESUPUESTO}

Para efectos de presupuesto, se incluirá un rubro presupuestario denominado Aporte Técnico que incluirá:

- los costos indirectos,

- las horas profesionales expertos,

- el salario del Coordinador Institucional de Proyecto,

- los días de preparación de los expertos y

- el valor agregado.

La suma de las anteriores da como resultado el Aporte Técnico Institucional.

El resto de las variables, es decir, los componentes de los Costos Directos, se listan de la siguiente manera: boletos aéreos, viáticos (alimentación y hospedaje), transporte interno; y materiales y suministros.

Todo lo anterior se suma y se le aplica (según sea el tipo de cooperación), el 5\% o 7\%, por concepto de Costos Indirectos. (Ver ejemplos). La suma final da la contrapartida institucional.

Para el caso de registro en el SIGECI de Mideplan, se registra únicamente el monto total de la contrapartida institucional.

Tabla 1. Variables y montos respectivos en dólares americanos.

\begin{tabular}{|c|c|c|c|c|c|c|}
\hline & $\begin{array}{c}\text { Este lo puede } \\
\text { aportar el } \\
\text { cooperante }\end{array}$ & \multicolumn{5}{|c|}{$\begin{array}{c}\text { Aporte Técnico } \\
\text { (de la institución costarricense) }\end{array}$} \\
\hline & $\begin{array}{l}\text { Costos } \\
\text { Directos (a) }\end{array}$ & Costos Indirectos (b) & $\begin{array}{l}\text { Salario } \\
\text { diario } \\
\text { (Horas } \\
\text { Expertos) } \\
\text { (c) }\end{array}$ & $\begin{array}{l}\text { Salario } \\
\text { mensual } \\
\text { Coordinador } \\
\text { Institucional } \\
\text { de } \\
\text { Proyecto }(d)\end{array}$ & $\begin{array}{l}\text { Días de } \\
\text { preparación } \\
(e)\end{array}$ & $\begin{array}{l}\text { Valor Agregado } \\
(f)\end{array}$ \\
\hline $\begin{array}{l}\text { Montos en } \\
\text { USD }\end{array}$ & $\begin{array}{lr}\text { Los costos } \\
\text { directos se } \\
\text { calculan según } \\
\text { cada proyecto. } \\
\text { (Cuando } \\
\text { aplica). }\end{array}$ & $\begin{array}{l}\mathbf{5 \%} \text { sobre el total de la contrapartida } \\
\text { institucional en } \\
\text { proyectos de } \\
\text { cooperación sur-sur y triangulación. } \\
\mathbf{7 \%} \text { sobre el total de la contrapartida } \\
\text { institucional en } \\
\text { proyectos tradicionales } \\
\text { bilaterales y } \\
\text { multilaterales. }\end{array}$ & $\begin{array}{c}\$ 115 / \text { día } \\
\mathrm{x} \\
\text { experto }\end{array}$ & $\$ 5,257$ & $\begin{array}{c}\$ 40 \mathrm{x} \\
\text { día/experto }\end{array}$ & $\begin{array}{l}\text { Junior: } \\
\$ 150 \\
\text { Senior: } \\
\$ 250\end{array}$ \\
\hline
\end{tabular}


- La sumatoria de (b) + (c) + (e) + (f) da el Aporte Técnico Institucional.

- El ítem (d) se incluye como un rubro aparte.

- El ítem (b) se aplica como indicado, al final de los cálculos.

- El total conforma la contrapartida institucional.

\section{EJEMPLO DE PRESUPUESTO PARA LA CONTRAPARTIDA EN UN PROYECTO DE COOPERACIÓN SUR-SUR Y TRIANGULACIÓN}

Ejemplo de presupuesto, por rubros y entidades (En dólares americanos)

\begin{tabular}{|c|c|c|c|c|}
\hline Rubros & $\begin{array}{c}\text { Costa Rica } \\
\text { (SINAC) }\end{array}$ & Alemania (GIZ) & $\begin{array}{c}\text { México } \\
\text { (AMEXCID) }\end{array}$ & Total \\
\hline $\begin{array}{c}\text { Coordinador } \\
\text { institucional de } \\
\text { proyecto x } 24 \text { meses a } \\
1 / 2 \mathrm{t} \text {, a } 2.628,5 / \mathrm{mes} \text {. }\end{array}$ & 75.584 & & & \\
\hline $\begin{array}{c}-1 \text { experto senior } \times 6 \\
\text { actividades } \\
\text { (talleres). }\end{array}$ & 2.735 & & & \\
\hline Boletos aéreos & & 10.000 & & \\
\hline Viáticos & & 15.000 & 5.000 & \\
\hline Transporte interno & & & 2.000 & \\
\hline Logística & & & 2.000 & \\
\hline Sistematización & & 15.000 & & \\
\hline Evaluación & & 20.000 & & \\
\hline Total & $82.084^{55}$ & 60.000 & 9.000 & \\
\hline
\end{tabular}

* Se aplicó el 5\% por concepto de costos indirectos por tratarse de un proyecto de cooperación triangular.

Cálculo de la contrapartida institucional:

a. Coordinador de proyecto:

$1 / 2$ t: $\$ 5,257$ (salario mensual) dividido entre $2=2.628,5$

$\mathrm{x}(2$ años $) 24$ meses $=69.084$

$+\$ 250(\mathrm{VA})$

$=\$ 75.584$

b. Experto senior:

1 experto a $\$ 115$ (salario diario) X 9 días total talleres (corresponde a 6 actividades)

$=1.035$

+20 días total preparación $=800$

+150 (VA) x 6 actividades $=900$

$=\$ 2.735$

$+5 \%$ costos indirectos (administrativos)

$=\$ 3.765$

Total contrapartida: $\$ 82.084$

\section{EJEMPLO DE PRESUPUESTO PARA LA CONTRAPARTIDA EN UN PROYECTO DE COOPERACIÓN BILATERAL}

Ejemplo de presupuesto, por rubros y entidades

\footnotetext{
55 Incluye el 5\% sobre el total Contrapartida institucional. Monto que debe aparecer en el SIGECI de MIDEPLAN.
} 
(En dólares americanos)

\begin{tabular}{|c|c|c|}
\hline Rubros & Costa Rica & Alemania (GIZ) \\
\hline $\begin{array}{l}1 \text { Director de proyecto } \times 24 \text { meses, } \\
\text { t/c a US } \$ 4.000 / \mathrm{mes} \text {. }\end{array}$ & & 96.000 \\
\hline $\begin{array}{c}1 \text { coordinador institucional de proyecto } \mathrm{x} 1 / 2 \mathrm{t} \text { a US } \$ 2.628,5 \mathrm{x} \\
\text { meses. }\end{array}$ & 75.584 & \\
\hline $\begin{array}{l}\text {-3 expertos junior x } 12 \text { meses a \$115/día + \$150(VA) x } 3 \\
\text { - } 1 \text { experto senior x } 12 \text { meses a } \$ 115 / \text { día + \$250 (VA) }\end{array}$ & $\begin{array}{l}62.500 \\
20.950\end{array}$ & \\
\hline Facilitadores 10 talleres & & 40.000 \\
\hline Logística talleres & & 20.000 \\
\hline Impresiones y materiales & & 10.000 \\
\hline Bolletos y viáticos & & 15.000 \\
\hline Transporte interno & 5.000 & \\
\hline Evaluación final & & 30.000 \\
\hline Total & $175.516^{56}$ & 211.000 \\
\hline
\end{tabular}

Nota: El cálculo a dólares se hace utilizando el tipo de cambio oficial del momento.

\section{Cálculo de la contrapartida institucional:}

a. Coordinador de proyecto:

$1 / 2$ t: $\$ 5,257$ (salario mensual) dividido entre $2=2.628,5$

$\mathrm{x}(2$ años $) 24$ meses $=69.084$

$+\$ 250(\mathrm{VA})$

$=\$ 75.584$

b. Expertos junior:

3 expertos a $1 / 2$ t: $\$ 115$ (salario diario) divido entre $2=57,5$

$\mathrm{X} 12$ meses ( 30 días x 12 meses $)=20.700$

$\mathrm{X} 3$ expertos $=62.100$

+150 (VA) $\mathrm{x} 3$

$=\$ 62.500$

c. Experto senior:

1 experto a $1 / 2 \mathrm{t}$ : $\$ 115$ (salario diario) dividido entre $2=57.5$

$\mathrm{X} 12$ meses (30 días x 12 meses) $=20.700$

$+250(\mathrm{VA})$

$=\$ 20.950$

d. Transporte interno:

Calculo según datos institucionales relacionados con viáticos chofer y gasolina$=\$ 5000$

$\underline{\text { Suma total: } 164.034}$

$+7 \%$ por concepto de costos indirectos (administrativos)

$=11.482$

Total contrapartida: $\$ 175.516$

${ }^{56}$ Incluye el $7 \%$ sobre el total. Total contrapartida institucional

LA PERSPECTIVA DE COSTA RICA SOBRE EL APOYO OFICIAL TOTAL PARA EL DESARROLLO SOSTENIBLE (TOSSD) @ OCDE 2019 
Anexo C: lista de instituciones entrevistadas para el piloto TOSSD en Costa Rica

Agencia de Promoción de Inversiones de Costa Rica (CINDE)

Agencia Española de Cooperación Internacional para el Desarrollo (AECID)

Alianza Empresarial para el Desarrollo (AED)

Banco Central de Costa Rica (BCCR)

Cámara Costarricense-Norteamericana de comercio de Costa Rica (AMCHAM)

Casa Presidencial

Consejo Nacional de Concesiones (CNC)

Coordinación residencia de las Naciones Unidas

Embajada de China

Embajada de México

Fundación Costa Rica Estados Unidos para la Cooperación (CRUSA)

FUNDECOOPERACION

INCOPESCA

Ministerio de Agricultura y Ganadería (MAG)

Ministerio de Asuntos Exteriores/ Cancillería

Ministerio de Ambiente y Energía (MINAE)

Ministerio de Comercio Exterior (COMEX)

Ministerio de Coordinación y Enlace con el Sector Productivo

Ministerio de Gobernación y Policía

Ministerio de Hacienda

Ministerio de Obras Públicas y Transporte (MOPT)

Ministerio de Planificación Nacional y Política Económica (MIDEPLAN)

Unión Europea 
Anexo D: estimación de flujos de costa rica como proveedor

\section{8 (Dólares \\ estadounidense, desembolsos)}

Refugiados

Ayuda Humanitaria

Costes Administrativos

Contribuciones a organismos internacionales, incluidas contribuciones

a operaciones de mantenimiento de la paz.

Cooperación Sur-Sur y triangular

Becas
Datos no disponibles

Datos no disponibles

$159.199,52$

9.344.056,28

Datos no disponibles

No aplica

\section{TOTAL $\quad 9.503 .255,81$}

Detalle de contribuciones a organismos internacionales

Descripción

Desembolsos

Colones

Costarricenses

Foro De Presidentes Legislativos Centroamericanos (Foprel).

14.570 .000

Unión Interparlamentaria Mundial.

12.152 .000

Parlamericas.

2.480 .000

Confederación Parlamentaria De Las Américas (Copa).

3.100 .000

Organización Latinoamericana Y Del Caribe De Entidades Fiscalizadoras Superiores.

5.122 .000

Organización Internacional De Entidades De Fiscalización Superior - Intosai.

289.000

Alianza Global De Las Instituciones Nacionales En Derechos Humanos (Ganhri)

3.000 .000

Comité Internacional De La Cruz Roja. (Cicr).

17.477 .460

Organización Internacional Proscripción De Armas Nucleares En América Latina Y Caribe.

1.966 .200

Organización De Las Naciones Unidas. (Onu).

695.041 .278

Programa Naciones Unidas Para El Desarrollo.

120.000 .300

198.336 .000

Programa De Las Naciones Unidas Para El Desarrollo. (Pnud).

Organización De Los Estados Americanos. (Oea). (Oficina De La Unión Panamericana En

16.063 .200

Organización De Estados Americanos. (Oea Fondo Regular).

144.644 .460

Instituto Panamericano De Geografía E Historia. (Ipgh).

3.249 .310

Secretaría De Cooperación Iberoamericana. (Secib).

13.005 .900

Relatoría Especial Para La Libertad De Expresión De La Corte Interamericana De Justicia.

1.763 .460

Asociación De Estados Del Caribe. (Aec).

29.202 .960

Onu - Mantenimiento De La Paz Y Tribunales Internacionales.

458.268 .273

Organización De Las Naciones Unidas. (Onu). (Grupo De Los 77).

2.927.460

Organización Internacional Para Las Migraciones. (Oficina En Costa Rica).

4.110 .085

Organización Del Tratado De Prohibición Completa De Ensayos Nucleares. (Ctbto).

37.520 .725

Fondo Comisión De Límites De La Plataforma Continental.

3.019 .300

Universidad Para La Paz.

29.100 .000

LA PERSPECTIVA DE COSTA RICA SOBRE EL APOYO OFICIAL TOTAL PARA EL DESARROLLO SOSTENIBLE (TOSSD) @ OCDE 2019 
Convención Sobre La Prohibición De Minas Antipersonales.

3.218 .460

Convención De Armas Biológicas.

291.000

Comision Interamericana De Derechos Humanos. (Cidh).

5.820 .000

Organización Para La Cooperación Y Desarrollo Económico (Ocde).

9.783.484

Organización Mundial De Aduanas.

Organización Para La Cooperación Y Desarrollo Económico (Ocde).

15.173 .952

Organización De Las Naciones Unidas Para La Agricultura Y La Alimentación (Fao).

12.222 .000

Instituto Interamericano De Cooperación Para La Agricultura (Iica).

98.376 .414

Federación Panamericana De Lechería (Fepale).

40.158 .000

1.746 .000

Organización De Las Naciones Unidas Para El Desarrollo Industrial (Onudi).

52.181 .400

Centro Para La Promoción De La Micro Y Pequeña Empresa En Centroamérica

20.370 .000

Organización Para La Cooperación Y El Desarrollo Económico (Ocde).

7.930 .000

Secretaria De Integracion Economica Centroamericana (Sieca).

Asociación Mundial De Carreteras (Piarc).

Facultad Latinoamericana De Ciencias Sociales (Flacso) Sede Académica En Costa Rica.

21.433 .125

2.455 .722

17.460 .000

Instituto Centroamericano De Administración Pública (Icap).

104.760 .000

Organización De Estados Iberoamericanos (Oei).

Oficina Subregional De La Educación Para América Latina Oreal/Unesco Santiago.

20.227 .410

Coordinación Educativa Y Cultural Centroamericana - Cecc

11.058 .000

12.611 .940

Organización Mundial De La Salud (Oms).

8.200 .000

Organización Mundial De La Salud (Oms).

102.675 .558

Organización Panamericana De La Salud (Ops).

123.670 .684

Consejo De Ministros De Salud De Centroamerica.

26.979 .750

Organismo Internacional De Energía Atómica (Oiea).

15.015 .000

Instituto De Nutrición De Centroamérica Y Panamá (Incap).

29.317 .680

Organización Iberoamericana De Seguridad Social (Oiss).

29.362.197

Programa Iberrutas.

7.566 .000

Programa Iberoamericano De Museos Ibermuseos

Unesco Convención Para La Salvaguardia Del Patrimonio Cultural Inmaterial.

17.460 .000

Programa Iberoamericano De Cultura (Ibercultura).

568.032

14.550 .000

Asociación De Bibliotecas Nacionales Iberoamericanas (Abinia).

2.007 .900

Instituto Latinoamericano Para La Prevención Del Delito Y El Tratamiento Del Delincuente

389.032 .000

Organización Para La Cooperación Y El Desarrollo Económico (Ocde).

8.975 .000

Organización Mundial De La Propiedad Intelectual (Ompi).

3.500 .000

Secretaría Permanente De Integración Económica Centroamericana (Sieca).

291.000 .000

Organización Para La Cooperación Y El Desarrollo Económico (Ocde).

58.000 .000

Centro Latinoamericano De Administración Para El Desarrollo. (Clad)

13.000 .000

Organización Para La Cooperación Y El Desarrollo Económico (Ocde).

7.700 .000

Organización Para La Cooperación Y Desarrollo Económico (Ocde).

9.100 .000

Unión Internacional Para La Conservación De La Naturaleza Y Los Recursos Naturales

9.661 .200

Comisión Centroamericana De Ambiente Y Desarrollo (Ccad).

11.640 .000

Convención Marco De Las Naciones Unidas Sobre Cambio Climático.

4.248 .600

National Marine Sanctuary Foundation.

1.164 .000

Programa De Las Naciones Unidas Para El Medio Ambiente (Pnuma).

1.280 .400

Fundación 5080 Cos.

3.510 .042 
Programa De Las Naciones Unidas Para El Medio Ambiente (Pnuma).

1.366 .536

Instituto Interamericano Para La Investigación Del Cambio Global.

2.910 .000

Organización Latinoamericana De Energía (Olade).

Asociación De Altas Jurisdicciones Administrativas. (Cuota De Afiliación, Según Acuerdo

15.534 .634

Comisión De Venecia Del Consejo De Europa (Para Pago De Cuota De Membresía, Según

707.680

Facultad Latinoamericana De Ciencias Sociales (Flacso) Sede Académica De Costa Rica.

3.007 .713

Parlamento Latinoamericano.

15.000 .000

Organización Internacional Para Las Migraciones. (Omi).

18.600 .000

Instituto Italo Latinoamericano. (Iila).

11.660 .370

Organización Para La Prohibición De Armas Químicas.

3.766 .460

Tribunal Internacional De Derecho Del Mar.

20.787 .850

Facultad Latinoamericana De Ciencias Sociales. (Flacso).

4.447 .560

Sistema De La Integración Centroamericana. (Sica).

54.999 .000

Alto Comisionado Para Los Derechos Humanos.

180.127 .780

Corte Penal Internacional.

5.837 .460

Conferencia De La Haya De Derecho Internacional Privado. (Cohadip).

75.913 .345

Convención Sobre La Prohibición De Municiones De Racimo.

3.363 .960

3.704 .730

Organización Internacional Del Cacao (Icco).

4.011 .260

Organización Marítima Internacional (Omi).

6.310 .000

Comisión Interamericana De Puertos (Cip), Organización De Estados Americanos

3.492 .000

Organización De Las Naciones Unidas Para La Educación, Ciencia Y La Cultura

89.062 .993

Organización Para La Cooperación Y El Desarrollo Económico-Ocde-

31.679 .910

Programa De Las Naciones Unidas Para El Medio Ambiente (Pnuma).

1.337 .328

Fondo De Naciones Unidas Para La Infancia En Costa Rica (Unicef).

10.470 .972

Coordinadora Educativa Cultural Cecc/Sica.

5.820 .000

Centro Regional Para El Fomento Del Libro En América Latina (Cerlac-Unesco).

Programa Iberoamericano Para La Preservación Del Patrimonio Sonoro Y Audiovisual

4.539 .600

2.910 .000

Organización Internacional De Energía Atómica

72.300 .000

Comisión Técnica Regional De Telecomunicaciones (Comtelca).

22.000 .000

Red De Información Ambiental Para América Latina Y El Caribe.

2.910 .000

1.455 .000

Programa De Las Naciones Unidas Para El Medio Ambiente (Pnuma).

2.037 .000

Programa Para Las Naciones Unidas Para El Medio Ambiente (Pnuma).

2.328 .000

Programa De Las Naciones Unidas.

10.883 .400

Organización Para La Cooperación Y El Desarrollo Económico (Ocde).

5.820 .000

Instituto Internacional De La Democracia Y De Asistencia Electoral (Idea).

3.100 .000

Asociación Mundial De Organismos Electorales (A-Web, Por Sus Siglas En Inglés).

6.200 .000

Alto Comisionado De Las Naciones Unidas Para Los Refugiados. (Acnur).

8.730 .000

Fondo Poblaciones De Las Naciones Unidas.

2.894 .400

Programa Naciones Unidas Para El Desarrollo.

81.000 .000

Corte Interamericana De Derechos Humanos.

58.200 .000

Autoridad Internacional De Los Fondos Marinos.

1.769 .280

4.074.000

Instituto Interamericano De Derechos Humanos.

5.238 .000

Sección Nacional Del Instituto Panamericano De Geografía E Historia. (Ipgh - Cr).

734.485

LA PERSPECTIVA DE COSTA RICA SOBRE EL APOYO OFICIAL TOTAL PARA EL DESARROLLO SOSTENIBLE (TOSSD) @ OCDE 2019 
Comisión Internacional Humanitaria De Encuesta. $\quad 122.450$

Convención Sobre Ciertas Armas Convencionales. $\quad 308.460$

Consejo De Ministros De Hacienda O Finanzas De Centroamérica, Panamá Y República $\quad$ 18.333.333

Centro Interamericano De Administración Tributaria (Ciat).

30.092 .892

Organización Para La Cooperación Y El Desarrollo Económico (Ocde)

32.803 .441

Asociación Iberoamericana De Tribunales De Justicia Fiscal O Administrativa. $\quad 582.000$

Centro Agronómico Tropical De Investigación Y Enseñanza (Catie). $\quad 29.100 .000$

Consejo Agropecuario Centroamericano (Cac).

Organización Para La Cooperación Y El Desarrollo Económico (Ocde). $\quad 7.930 .000$

Comisión Centroamericana De Transporte Marítimo (Cocatram). $\quad 1.746 .000$

Oficina Surregional De La Unesco Para Centroamerica Y Panamá. $\quad 52.803 .696$

Organización Internacional Del Trabajo (Oit). $\quad 101.513 .468$

Organización Iberoamericana De Seguridad Social (Oiss). $\quad 5.219 .801$

Programa De Las Naciones Unidas Para El Desarrollo (Pnud) $\quad 70.000 .000$

Organización De Las Naciones Unidas Para La Educación, La Ciencia Y La Cultura $\quad 587.820$

$\begin{array}{lr}\text { Sistema Económico Latinoamericano (Sela). } & 6.431 .100\end{array}$

Programa Iberoamericano De Bibliotecas Públicas (Iberbibliotecas). $\quad 8.730 .000$

$\begin{array}{lr}\text { Organismo Mundial Del Comercio (Omc). } & 88.000 .000\end{array}$

Centro Internacional De Arreglo De Diferencias Relativas A Inversiones (Ciadi). $\quad 320.650 .000$

Instituto Latinoamericano Y Del Caribe De Planificación Económica Y Social. Comisión $\quad 27.000 .000$

Unión Internacional De Telecomunicaciones (Uit). $\quad 44.500 .000$

Unión Internacional Para La Conservación De La Naturaleza (Uicn). $\quad 1.169 .238$

Programa De Las Naciones Unidas Para El Medio Ambiente (Pnuma). $\quad 8.099 .694$

Programa De Las Naciones Unidas Para El Medio Ambiente (Pnuma). $\quad 8.148 .000$

Organización Meteorológica Mundial (Omm). 19.791 .492

Comité Regional De Recursos Hidráulicos. $\quad 24.007 .500$

Organización Internacional De Polícia Criminal (Interpol). (Para Pago De Cuota De $\quad 30.000 .000$

$\begin{array}{lr}\text { Instituto Interamericano De Derechos Humanos. } & 3.100 .000\end{array}$

5.302.873.412

Tipo de cambio colones Costarricenses/Dólares norteamericanos 2017 OCDE (último disponible)

567.513

Dólares estadounidenses $\quad 9.344 .056,28$ 


\section{Referencias}

Aid Data (2018) Perfil de china, Aid Data Washington DC, retrieved from https://china.aiddata.org.

Banco Mundial. (2016). Doing Business Economy Profile 2017: Costa Rica. Banco Mundial, Washington, DC. World Bank. https://openknowledge.worldbank.org/handle/10986/25500.

Banco Mundial (2017) Estadísticas del Banco Mundial, Banco Mundial, Washington DC. , https://data. worldbank.org/indicator/BX.TRF.PWKR.CD?end=2017\&start=1960

Banco Mundial (2018): Doing Business in Costa Rica 2018, Banco Mundial, Washington DC. http://www.doingbusiness.org/ /media/WBG/DoingBusiness/Documents/Profiles/Country/CRI.pdf.

Benn, J., et al. (2016), "Amounts Mobilised from the Private Sector by Official Development Finance Interventions: Guarantees, syndicated loans and shares in collective investment vehicles", OECD Development Co-operation Working Papers, No. 26, Edición OCDE, París, https://doi.org/10.1787/5jm3xh459n37-en.

Benn, J., C. Sangaré and T. Hos (2017), "Amounts Mobilised from the Private Sector by Official Development Finance Interventions: Guarantees, syndicated loans, shares in collective investment vehicles, direct investment in companies, credit lines", OECD Development Co-operation Working Papers, No. 36, Edición OCDE, París, http://dx.doi.org/10.1787/8135abde-en and tools for data visualisation.

CEPAL (2016) El enfoque de brechas estructurales: Análisis del caso de Costa Rica Santiago de Chile, CEPAL Santiago de Chile, https://www.cepal.org/es/publicaciones/40805-enfoque-brechasestructurales-analisis-caso-costa-rica

Comisión Europea (2018): International Co-operation and Development: Costa Rica, https://ec.europa.eu/europeaid/countries/costa-rica_en.

Delalande G. and V. Gaveau (2018) "Senegal's perspective on TOSSD" OECD Development Cooperation Working Papers No. 43 Edición OCDE, París, http://dx.doi.org/10.1787/4144f82a-en

Delalande G. Et al. (2018) "Nigeria's Perspective on Total Official Support for Sustainable Development (TOSSD)" OECD Development Co-operation Working Papers No. 50 Edición OCDE, París, https://doi.org/10.1787/619cb021-en.

Delalande G. R. Halvorson-Quevedo and C. Sangaré (2018) “The Philippines' perspective on TOSSD" OECD Development Co-operation Working Papers No. 42 Edición OCDE, París, http://dx.doi.org/10.1787/6ecaa5ac-enS.

EIU (2018): Country Forecast July 2018: Costa Rica, https://store.eiu.com/product/country-report/costarica.

FMI (2018): Costa Rica 2017 - Article IV Consultation, IMF Washington DC, https://www.imf.org/en/Publications/CR/Issues/2017/06/27/Costa-Rica-2017-Article-IVConsultation-Press-Release-and-Staff-Report-44991

Foro Económico Mundial (2018): Perfil de país: Costa Rica, http://www3.weforum.org/docs/gcr/20152016/CRI.pdf.

Global Financial Integrity (2017), Global Financial Integrity, Washington DC. http://www.gfintegrity.org/wp-content/uploads/2017/05/GFI-IFF-Report-2017_final.pdf 
Naciones Unidas (2015), Human Development Index of Costa Rica, Naciones Unidas Nueva York, consultado en country economy (página web) https://countryeconomy.com/hdi/costa-rica.

NDC (2017): Country Outlook: Costa Rica, https://ndcpartnership.org/sites/all/themes/ndcp_v2/docs/countryengagement/countries/NCDP_Outlook_Costa-Rica_v4a.pdf.

OCDE (n.d.[1]), Creditor Reporting System, OECD Paris, https://stats.oecd.org/

OCDE (2015): Public Governance Reviews: Costa Rica: Highlights, OECD https://www.oecd.org/gov/bycountry/costarica/costa-rica-highlights.pdf.

OCDE (2016) OECD Economic Surveys: Costa Rica 2016: Economic Assessment OECD Publishing Paris https://doi.org/10.1787/eco_surveys-cri-2016-en.

OCDE (2018a) OECD Economic Surveys: Costa Rica 2018 OECD Publishing Paris https://doi.org/10.1787/eco_surveys-cri-2018-en.

OCDE (2018b), "2018 Survey on Amounts Mobilised from the Private Sector by Development Finance Interventions", Base de datos de estadísticas internacionales de la OCDE, OCDE París, http://www.oecd.org/dac/financing-sustainable-development/development-financestandards/mobilisation.htm

OECD (n.d.), "Creditor Reporting System: Aid activities", Base de datos de estadísticas internacionales de la OCDE, OCDE París, https://doi.org/10.1787/data-00061-en,

Transparencia Internacional (2018): Índice de percepción de la corrupción 2017: Costa Rica, https://www.transparency.org/news/feature/corruption_perceptions_index_2017. 


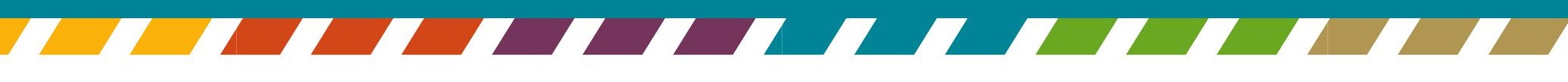

